\title{
ASSESSING MARKETS FOR RENEWABLE ENERGY IN RURAL AREAS OF NORTHWESTERN CHINA
}

Tuntivate Voravate

Douglas F. Barnes

V. Susan Bogach 
(copyright page) 


\section{CONTENTS}

Abstract ........................................................................................................................................ vii

Acknowledgments..................................................................................................................viii

Abbreviations and Acronyms..................................................................................................... ix

Currency Equivalents ............................................................................................................................ $\mathrm{x}$

Units of Measure............................................................................................................................. $\mathrm{x}$

EXECUTIVE SUMMARY .................................................................................................. 1

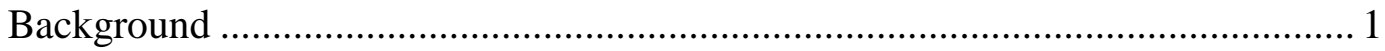

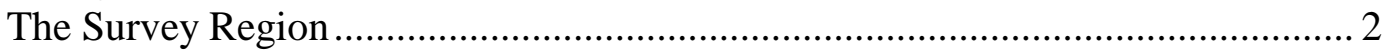

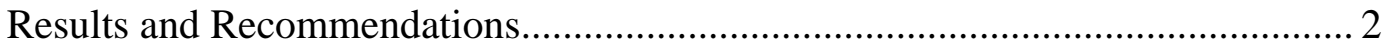

Target Population Characteristics ................................................................. 3

Familiarity with Credit ................................................................................... 3

Awareness of Benefits of Electricity .................................................................. 3

Existing Use of Renewable Energy Technologies ................................................. 4

Characteristics of Existing Owners of photovoltaic systems ................................... 4

Experience with Photovoltaic Systems ...................................................... 5

Potential Markets for Photovoltaic Systems ..................................................... 5

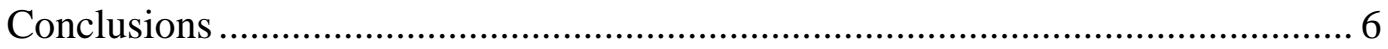

1. Background..........................................................................................................................................

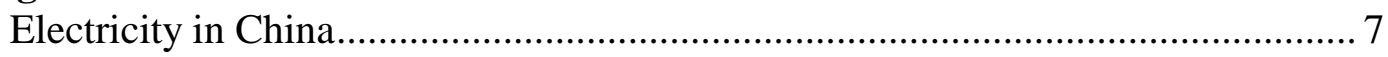

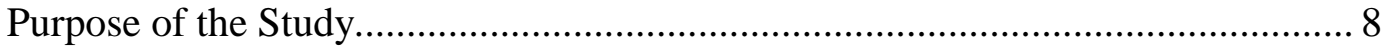

2. Background on Areas Targeted by the Survey .................................................................. 11

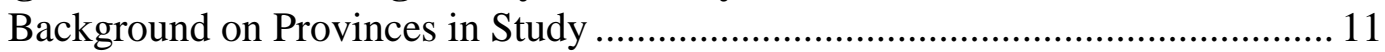

Current Photovoltaic System Business............................................................... 12

Description of Typical Photovoltaic Systems Used in Rural Areas in China ....... 14

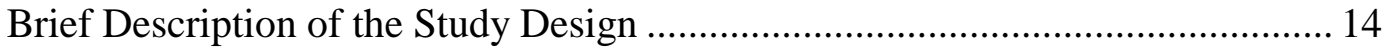

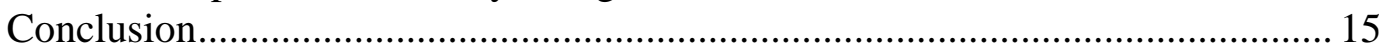

\section{Survey Results: Socioeconomic Characteristics of Households without}

Electricity .......................................................................................................................... 17

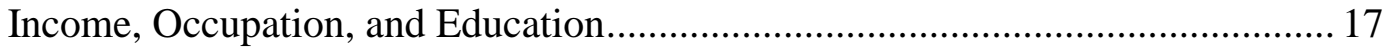

Value of Rural Household Assets ...................................................................... 19

Experience with Banking and Credit.................................................................. 22

Current Energy Use and Expenditure for Household Lighting ............................. 25 
Attitudes and Preference toward Energy Services ............................................ 31

Knowledge of and Access to Photovoltaic Systems........................................... 35

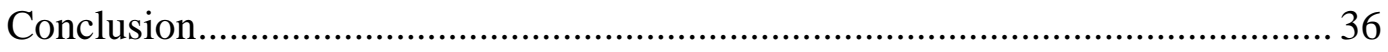

4. Profile of Households with Photovoltaic Systems........................................................ 37

Profile of Photovoltaic System Owners ............................................................. 37

The Type of Photovoltaic System Purchased by Households .............................. 41

System Performance and Quality of Service .................................................. 43

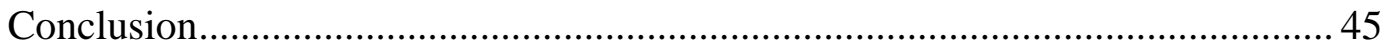

5. Potential Market for Photovoltaic Systems in Four Provinces .............................. 47

Ability to Pay Cash for Photovoltaic Systems ................................................. 47

Potential Demand for Larger Systems.......................................................... 49

Attitudes and Preferences for Types of System and Payment Methods ............... 50

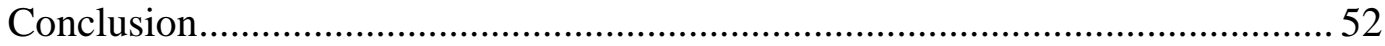

6. Conclusions and Recommendations ....................................................................5 53

The Market for Photovoltaic Systems Exists and Is Growing ........................... 53

Households Appear to Have Little Interest in Using Credit to Purchase

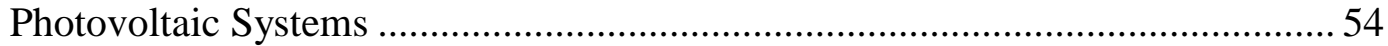

Sales and After-Sales Networks Need to Be Expanded ...................................... 55

Standards and Specifications May Be Important for Market Development........... 55

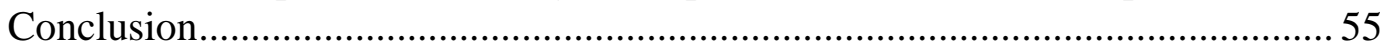

Appendix A: Descriptive Statistics from the Northwest China Rural Energy

Survey ........................................................................................................................................... 57

Appendix B: Data and Sampling Methods .............................................................. 79

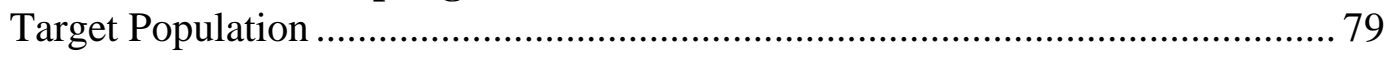

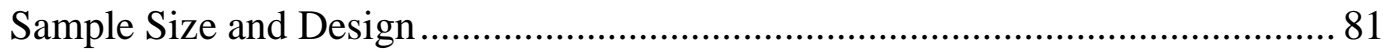

Purposive Selection of Photovoltaic Households.............................................. 84

Questionnaire and Conduct of the Survey..................................................... 85

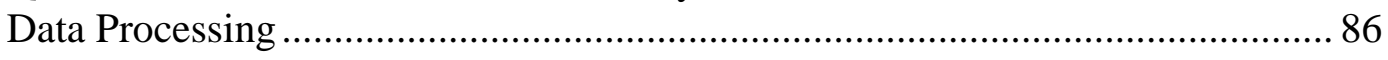

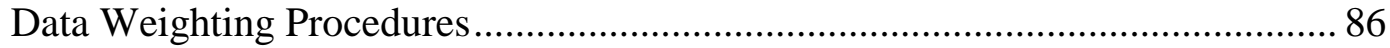

Estimation of Standard Errors and Confidence Interval................................... 87

Appendix C: Questionnaire......................................................................................................90

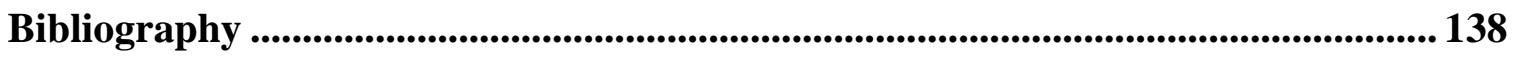

\section{Map IBRD 30439}




\section{Tables}

2.1 Socioeconomic Characteristics of Four Provinces in Survey, 1997

2.2 Households without Electricity in Counties and Provinces

3.1 Household Monthly Income by Type of Occupation of Household Head

3.2 Average Value of Livestock Classified by Occupation of Head of Household and Type of Asset

3.3 Household Borrowing Patterns in Villages without Electricity in Four Provinces

3.4 Household Use of Loans in Villages without Electricity in Four Provinces

3.5 Comparison of Income and Value of Livestock between Households that Have Not and Have Taken a Loan Before

3.6 Household Energy Use for Lighting by Income Class

3.7 Household Monthly Spending for Lighting Energy

3.8 Monthly Spending on Lighting for Households Using Renewable Energy Systems

3.9 Household Energy Attitudes and Lighting Preferences

3.10 Satisfaction with Lighting Source According to Electricity Source

3.11 Household Knowledge of Renewable Energy Systems

4.1 Owners of Photovoltaic Systems Whose Household Monthly Income Falls within Each Income Category of All Households

4.2 The Nature of Photovoltaic System Purchases in Four Provinces

4.3 Experiences with Repairs and Services

5.1 Households That Could Afford Small Photovoltaic Systems

5.2 Households That Could Afford to Purchase Large Photovoltaic Systems

5.3 Households Interested in Buying a Different Size Photovoltaic System Using Cash or Credit

A-1 Socioeconomic Indicators

A-2 Households' Experience with Credit

A-3 Household Energy Use for Lighting

A-4 Households' Energy Expenditure

A-5 Household Energy Attitude and Lighting Preferences

A-6 Households That Have Heard about or Have Seen 20-Watt Photovoltaic Systems

A-7 Households That Are Interested in Buying 20-Watt Photovoltaic Systems

A-8 Reason for Not Being Interested in Purchasing 20-Watt Photovoltaic Systems

A-9 Households That Have Heard about or Have Seen 50-Watt Photovoltaic Systems

A-10 Households That Are Interested in Buying 50-Watt Photovoltaic Systems

A-11 Reason for Not Being Interested in Purchasing 50-Watt Photovoltaic Systems

A-12 Households That Have Heard about or Have Seen Small Hybrid PhotovoltaicWind Systems

A-13 Reason for Not Being Interested in Purchasing Hybrid Photovoltaic-Wind Systems

A-14 Photovoltaic Systems Owned by Households

A-15 Attitude toward Photovoltaic Systems among System Owners

A-16 Reasons for Photovoltaic System Owners to Obtain Systems

A-17 Perceived Benefits of Photovoltaic Systems among System Owners

A-18 Attitude of Photovoltaic System Owners toward System Performance 
A-19 Changes in Lifestyles of Photovoltaic System Owners

B-1 Rural Households and Unelectrified Households

B-2 Targeted Households in Villages without Grid Electricity in Four Selected Provinces

B-3 Households in Villages without Grid Electricity in Sampled Counties and All Other Counties

B-4 Sample Selection for Photovoltaic Market Survey in Four Selected Provinces in China

B-5 Sample Size Broken Down by Random and Purposive Selection of Households

B-6 Weight Adjustment for County

B-7 Weight Adjustment for Province

B-8 Final Weight Adjustment Procedure

B-9 Estimated Variance and Standard Errors of Household Monthly Income in Gansu

B-10 Summary of Standard Error and Confidence Interval

\section{Figures}

3.1 Total Monthly Spending on Lighting Fuel in Energy and Electricity

3.2 Total Monthly Spending on Lighting Energy and Electricity

4.1 Distribution of Owners of Photovoltaic Systems Based on Income Deciles

4.2 Distribution of Photovoltaic Owners Based on Income and Assets Owned

4.3 Average Size of Photovoltaic System Owned by Income 


\begin{abstract}
The main objective of this study was to determine the market potential for photovoltaic systems in the remote areas of China, especially in villages without access to grid electricity. A number of photovoltaic systems have been sold in the remote provinces, but the size and nature of this market was not well understood. The study produced data that addresses several needs. It yielded an estimate of the size of the potential market for photovoltaic systems in four Chinese provinces; provided important information on the characteristics, ability to pay, and preferences of potential customers; detailed positive and negative experiences with existing photovoltaic systems; and developed recommendations to increase the penetration of photovoltaic systems in rural China as part of the upcoming China Renewable Energy Development Project. The main conclusion of the report is that there is significant desire by households in remote areas for electricity, and that there is significant potential market demand for photovoltaic systems.
\end{abstract}




\section{ACKNOWLEDGMENTS}

We gratefully acknowledge the support of the Japanese Grants for Preparation of the Renewable Energy Development Project and assistance from the Netherlands Alternative Energy Policy and Project Development Trust Fund in Support of the Asia Alternative Energy Program, which provided funding to carry out the survey in China and supported analysis of the data by local and international experts.

The efforts of the staff of the Center for Renewable Energy Development (CRED) deserve special mention for organizing and supervising the field survey work under very difficult conditions, for entering and verifying the data, and for drafting a report on the findings of the survey. CRED's team was led by Ms. Li Jingjing in the early stages of the survey work and by Mr. Li Junfeng throughout most of the work. Many other CRED staff members made substantial contributions to this project.

The authors would like to acknowledge the guidance provided throughout the course of the project by Mr. Noureddine Berrah, the Task Team Leader, who supervised, reviewed, and provided extensive support for the completion of the work. Mr. Liu Hongpeng, of the State Economic and Trade Commission, also provided extensive guidance, support, and comments during the survey. The report owes much to their guidance and support.

We would like to thank Jeremy Levin, who wrote the executive summary and abstract and assisted in the report's preparation, as well as Rebecca Kary of Alpha-Omega Services, Inc., who edited the report.

We would also like to thank several reviewers of the report, who made useful contributions. The reviewers included Messrs. Richard Spencer, Anil Cabraal, and Enno Heijndermans (World Bank); and Mr. Jim Finucane and Ms. Miao Hong (consultants). 


\section{ABBREVIATIONS AND ACRONYMS}

CRED Center for Renewable Energy Development

ESMAP Energy Sector Management Assistance Programme

GEF Global Environment Facility

PV Photovoltaic

TVE Township and village enterprise 


\title{
CURRENCY EQUIVALENTS
}

(1998)

\author{
U.S. dollars $(\$)=$ currency equivalent \\ $\$ 1.00=8.3$ yuan
}

\section{UNITS OF MEASURE}

$\begin{array}{ll}\text { GW } & \text { Gigawatt } \\ \text { kW } & \text { Kilowatt } \\ \text { kWh } & \text { Kilowatt-hour } \\ \mathrm{Mu} & \text { Chinese unit of land measurement } \\ \mathrm{MW} & \text { Megawatt } \\ \mathrm{W} & \text { Watt }\end{array}$




\section{EXECUTIVE SUMMARY}

There is a growing consensus that renewable energy will play a significant role in future development programs. This consensus has grown out of such reports as the United Nations Development Programme's "Energy after Rio," Shell Petroleum's "Energy for Development," and the World Bank's recent papers on "Fuel for Thought" and "Rural Energy and Development." In spite of this acceptance, surprisingly few studies have been made on the emerging markets for renewable energy in most countries.

The main purpose of this study was to determine the market potential for photovoltaic systems in the remote areas of China, especially in villages without access to grid electricity. A number of photovoltaic systems have been sold in the remote provinces, but the size and nature of this market is not well understood. The study produced information that addresses several needs. It estimated the size of the potential market for photovoltaic systems in four Chinese provinces. It provided important information on the characteristics, ability to pay, and preferences of potential customers. It detailed positive and negative experiences with existing photovoltaic systems, and it developed recommendations to increase the penetration of photovoltaic systems in rural China as part of the upcoming China Renewable Energy Development Project. The main conclusion of the report is that households in remote areas have a significant desire for electricity, and that a significant potential market exists for photovoltaic systems in many regions.

\section{BACKGROUND}

During the last 40 years, the Chinese program to provide electricity to rural populations achieved remarkable success. Today the percentage of households with access to electricity from large and small grid systems is approximately 93 percent, representing more than 96 percent of the villages in China.

Despite this success, a great many people still have no access to electricity in the remote areas of China. Approximately 75 million people do not have access to electricity from a local or regional grid system. In these remote provinces, the people are relatively poor, and the population density is low. Compared with other areas of China, little business or commercial activity exists. The low demand and sparse populations make it very expensive to reach these areas through grid extension. Hence, they are unlikely to be connected to the national grid for many years.

Retailers have been very active in selling renewable energy systems in the northwestern provinces of China, both wind and photovoltaic. Based on reports from 
photovoltaic companies, an estimated 45,000 photovoltaic systems were sold in 1997 alone, primarily on a cash basis. Little is known, however, about the potential size of the market for photovoltaic systems in these remote areas. None of the photovoltaic system retailers and distributors servicing these areas has conducted any type of formal survey to determine the size of the market for renewable energy systems.

The World Bank has recently approved a loan and Global Environment Facility (GEF) grant to China for the Renewable Energy Development Project (LN 4488-CHA, 1999), which includes a large photovoltaic component. This component will provide assistance to photovoltaic system companies to market, sell, and maintain an estimated $300,000-400,000$ systems in the remote areas of China's northwestern provinces. The results of this study are intended to help guide the implementation of the photovoltaic component.

\section{THE SURVEY REgION}

The survey was conducted in four remote provinces in China-Gansu, Inner Mongolia, Qinghai, and Xinjiang. All these provinces will be served by the recently approved Bank project. The target population (also known as the "population frame") within these provinces for the photovoltaic market survey consisted of all rural households living in villages without access to grid electricity in counties where more than 15 percent of households did not have electricity. ${ }^{1}$ The main reason that the market survey concentrated on such counties was that the villages without electricity in these counties have less chance of gaining access to electricity in the near future.

The photovoltaic market survey in the rural areas in Gansu, Inner Mongolia, Qinghai, and Xinjiang Provinces was conducted using a multistage random sampling design. Responses to detailed questionnaires were gathered from 2,286 households between August 1998 and April 1999.

\section{RESULTS AND RECOMMENDATIONS}

The survey yielded important information on the characteristics of the target population, their familiarity with the use of credit, their energy preferences, their use of remote renewable energy technologies, the characteristics of existing owners of photovoltaic systems, and observed experiences with solar home systems. Recommendations for increasing the acceptance of photovoltaic systems were developed based upon these observed results, and they are highlighted below.

\footnotetext{
${ }^{1}$ The 15 percent cutoff point was arbitrarily chosen based on the average 17 percent unelectrified rate in the combined 4 provinces.
} 


\section{Target Population Characteristics}

The provinces differ significantly in income, occupation, and education. The average monthly household incomes of the target population in the provinces range from a low of about Y 200 in Gansu to more than 1,300 in Inner Mongolia. Significant variations also exist in the occupations of the respondents: more than 90 percent of the households in unelectrified areas of Gansu are farmers, while more than 60 percent of the households in comparable areas of Inner Mongolia are herders. Quinghai has an even higher percentage of herders than Inner Mongolia, although they do not earn as much income as the Inner Mongolian herders. Xinjiang is predominantly a farming area. Its high average income level (Y 713) is probably attributable to its greater share of highvalue cash crop production. The education levels in the provinces are very high for such remote areas. Only one out of the four provinces has very low levels of education: Qinghai-where the rural households in the areas without electricity have the lowest educational levels. These variations in income, occupation, and education will lead to differing markets for photovoltaic systems in each of the provinces.

In addition to collecting data on yearly household income, the study estimated the assets of the rural households. Comparing the assets of farmers to those of herders revealed a pattern similar to that of yearly household income. In general, herders have higher incomes and greater total assets than farmers, making them more likely to be able to afford renewable energy systems.

The conclusion is that a significant number of households in the target population can afford to purchase photovoltaic systems, even on a cash basis.

\section{FAMiliarity WiTh CREDit}

Many people in these provinces are familiar with credit. Between 30 and 40 percent of the households in three of the provinces already have experience with obtaining credit from rural banks, credit unions, or other sources. Although households are very likely to borrow money for productive uses (such as agricultural inputs), there is no indication that they would borrow money for photovoltaic systems that improve the quality of life.

The household predisposition to borrow for photovoltaic systems should be investigated further to ensure that all potential approaches to increasing the affordability of photovoltaic systems are fully pursued.

\section{AWARENESS OF BENEFITS OF EleCtriCity}

The findings of the study verify that most households are aware of the benefits of electricity, and would like to have access to the better lighting, entertainment, and 
information made possible by electricity. Higher-income households are more dependent on electric lighting than others, and are willing to pay a very high price for electricity.

The results of the study clearly demonstrate that the benefits of electricity are widely recognized by rural households. This represents a key factor in the demand for photovoltaic systems in areas with no immediate prospects for grid access and high costs of alternative sources of electricity.

\section{EXISTING USE OF RENEWABLE ENERGY TECHNOLOGIES}

Interestingly, a significant number of households in remote areas without electricity are already using renewable energy sources, such as wind and, to a limited degree, photovoltaic systems. Even the households with photovoltaic and wind energy systems, however, are not totally satisfied with the service they are receiving. The survey noted that customers were dissatisfied with the seasonal variation from wind system power output. Furthermore, there is some evidence of discontent with the quality and quantity of lighting received from renewable energy, which includes solar and wind. Close to 40 percent of surveyed owners of photovoltaic systems reported that the photovoltaic systems they owned were too small and do not provide enough electricity for their families' needs. Despite the presence of a developing photovoltaic market, not all households in the sample areas of this study were aware of photovoltaic systems. About one-third of the households in the provinces had never heard about photovoltaic systems.

An emerging market for photovoltaic systems is developing in the northwestern provinces of China, even on a cash-only basis. At present, this market is at an early stage of development, as commercial retailers have only begun to service these provinces during the last three years. There is a need to increase both the awareness and availability of photovoltaic systems. Finally, given the intermittent nature of electricity from wind systems, the possibility of developing small and inexpensive hybrid systems should be explored.

\section{CHARACTERISTICS OF EXISTING OWNERS OF PHOTOVOLTAIC SYSTEMS}

Existing photovoltaic system owners tend to have higher incomes, greater assets, and more education than those who do not own systems. Income and the total value of assets owned, particularly livestock, are complementary indicators of whether households can afford to purchase a photovoltaic system.

The measured ability to pay is a fairly good indicator of potential photovoltaic purchasers, as is education level. The relatively large numbers of better-educated households and higher income and asset levels indicate that there is a large potential market for photovoltaic systems. 


\section{EXPERIEnCE With Photovoltaic Systems}

Most households that have purchased photovoltaic systems have chosen systems that were affordable, but which did not give the level of electricity service they desired, for example, enough lighting. Most systems in the region surveyed are less than two years of age and are relatively small in size, 20 watts or less.

Although the majority of systems seem to be performing well, several problems have been observed with lamp and battery performance. Additionally, when systems do need repairs, few convenient facilities are available. The average wait time for repairs is about one month. In spite of the problems, almost all photovoltaic system owners across all four provinces are satisfied with the performance of their systems and would recommend them to relatives or friends.

Therefore, a significant market may exist to upgrade the existing typical 20-watt systems. A modular approach may be warranted, in which a household has a choice of different types of systems that offer an easy upgrade path to larger systems. Rather than concentrating on one-time sales, the market should be viewed as a continuing source of sales of equipment and upgrades.

Most households in the remote areas have no access to the retailers that sell networks. Even in areas where photovoltaic systems have been sold, there is very little in the way of after-sales support. Assistance needs to be provided to accelerate the growth in sales of photovoltaic systems and after-sales support networks to increase access to photovoltaic systems and reduce waiting time for repairs. The adoption of mandatory standards, certification of photovoltaic products, and perhaps a modular approach to sales will help address the quality and performance problems identified in the study.

\section{Potential Markets for Photovoltaic Systems}

The results of the survey allow for an estimation of the potential market size for sales of photovoltaic systems by using the observed income and asset levels of the respondents. This analysis is based on a comparison of characteristics of rural households living in villages without grid electricity services and a profile of current photovoltaic system owners. Forty-one percent of rural households in the four provinces have levels of income and assets similar to those who have already purchased small photovoltaic systems with cash, representing 562,573 households that can afford to purchase small photovoltaic systems in the four provinces. Furthermore, it is estimated that approximately 264,515 of these households can afford to buy larger photovoltaic systems (greater than 50 watts) with cash. Based on the observed dissatisfaction with the limited capacity of smaller systems, it is conceivable that the demand for larger photovoltaic systems will increase in the near future. 


\section{CONCLUSiOnS}

A market for photovoltaic systems is emerging in the northwestern provinces of China, even on a cash basis. At present this market is in an early stage of development, because commercial retailers have only begun to service these provinces during the last three years.

Several obstacles must be overcome to expand this market: the lack of interest in credit for photovoltaic system purchases by households, which limits their ability to pay for photovoltaic systems, and the weak existing sales and after-sales networks in the region. Other obstacles include competition from alternative sources of electricity, such as diesel or gas generators and wind systems, and potential quality concerns with existing photovoltaic systems.

Despite these obstacles, this study revealed that significant opportunities exist for introducing photovoltaic systems in the rural areas of China. Many households can already afford to purchase small systems on a cash basis. This number could be significantly expanded if the use of credit to purchase systems was widely available and accepted. Furthermore, there appears to be a market for photovoltaic system expansion, beyond the initial purchase of smaller, more affordable systems. This market includes both upgrades to existing small photovoltaic systems and possible hybridization with existing wind systems. Overall, the market for photovoltaic products is likely to expand quickly. Households in the areas seem to appreciate the benefits of electricity service from the systems, and many have the necessary income to pay for systems. 


\section{BACKGROUND}

The potential for renewable energy in developing countries has been a topic of great interest among international development specialists in recent years. Several recent reports have highlighted renewable energy as a long-term contribution to global energy supplies, such as the United Nations Development Programme's "Energy after Rio," Shell Petroleum's "Energy for Development," and the World Bank's recent papers on "Fuel for Thought" and "Rural Energy and Development." All these reports endorse the development of renewable energy, as well as the relevance for future energy strategies in developing countries.

Despite the growing acceptance that renewable energy will play a greater role in future development programs, surprisingly few good studies have been made on the markets for renewable energy in most countries. Without an understanding of the unique niche or market for renewable energy systems, programs can be misguided and waste valuable resources in attempting to develop markets where little potential exists for systems sales. In fact, many programs involving household photovoltaic systems have experienced implementation problems.

This survey on the potential market for household photovoltaic systems in the northwest part of China, carried out as part of a World Bank project, demonstrates the value of proper market assessments. The results of the study are being utilized to guide the strategies to promote the sales of household photovoltaic systems under the project. In addition, the study should provide a useful benchmark or good practice model for future studies on how to identify and assess market segments in the development of rural and renewable energy programs. To this end, appendixes to this report include a descriptive list of tables from the survey (Appendix A); a description of the methodology and the sample design (Appendix B); and the questionnaire (Appendix C) used in the market study.

\section{Electricity IN CHINA}

China is one of the handful of developing countries in which a high percentage of people have access to electricity. During the last 40 years, programs to provide electricity to rural populations have achieved remarkable success. Today the percentage of households in China with electricity from large and small grid systems is about 93 percent, including more than 96 percent of the country's villages. The rural electrification program has also been very different from those in other countries. In China, the responsibility of providing electricity service to rural areas was delegated to local power companies. At first, most of the companies were very small, and coverage was limited to 
the main cities and towns. The companies had the responsibility of both local generation and distribution of electricity. This was often accomplished through local networks connected to small coal-generating stations and mini- and microhydropower systems. Today the national grid also reaches many of these small regional power companies, complementing and sometimes replacing the original power plants. More recently, a small amount of China's electricity supply has been provided by renewable energy resources, such as wind, solar, and geothermal energy.

The wide availability of electricity in both urban and rural areas in China is a major accomplishment. Despite this success in reaching hundreds of millions of people in the countryside, though, many people are still without electricity in the remote areas of China. About 75 million people do not have access to electricity from a local or regional grid system. In these remote provinces, the populations are relatively poor and can be very sparsely distributed. Many of the people make their living by farming and herding. The grid is unlikely to reach them for many years to come. Compared with other areas of China, there is little business or commercial activity. As a consequence, most of the demand for electricity comes from rural households. The low demand and sparse populations make it very expensive to reach these areas by extending the electricity grid.

Despite the remoteness of these areas, retailers have recently dramatically stepped up sales of renewable energy systems - particularly wind (starting in the early 1980s) and photovoltaic home systems (during the last three years). Based on the sales information, about 45,000 photovoltaic systems alone are reported to have been sold in 1997. Almost all the systems were sold on a cash basis. Because the market is still in the early stage of development, little is known about the potential and size of the market for renewable energy systems in general and photovoltaic systems in particular in such remote areas. Although some photovoltaic system distributors are already servicing these areas, none of them has conducted a formal survey to determine the size of the market for renewable energy systems.

\section{Purpose OF THE Study}

The overall purpose of this study was to determine the size of the potential market for renewable energy systems in the remote areas of Northwest China by focusing mainly on household photovoltaic systems. Very few reliable government statistics exist for these remote areas. The number of systems being sold suggests that there is a market, but the size and nature of the market is not well understood. One could question whether the market is big enough to justify the increased sales that would result from a World Bank lending operation. To answer this question, several different types of information on the market for photovoltaic systems were required.

One important question that was answered by the market survey is what size systems should be developed for rural markets. The traditional view has been that households would not want systems below 50 watts, because they would not supply 
sufficient power. However, recent studies have indicated that because of the cost, many people are purchasing the smaller rather than the larger systems. Thus, it is important to characterize the market for different sizes of photovoltaic systems and to profile the groups of people who already own such systems.

A second issue involved the willingness or ability of rural households to pay for photovoltaic systems. This study was fortunate to have access to many households in the remote provinces that already own photovoltaic systems. As a consequence, the income and attitudes of these households could be compared with those that do not yet have them. This provided a firm basis for estimating or understanding the willingness to pay for household systems.

Another goal of the study was to examine the role that credit might play in expanding the sales of household photovoltaic systems in the rural areas without access to electricity. Credit is an obvious way to make the purchase of photovoltaic systems more affordable to people with low incomes. We know that today most of the purchases of renewable energy systems are on a cash basis, and previous work in these areas has not dealt with credit issues. Therefore, the study documented the household experience with credit, and whether households are predisposed to borrow money for the purchase of a household photovoltaic system.

Finally, the market survey also addressed the issue of whether adequate after-sales support is available for photovoltaic systems in the areas where systems are being sold. Much has been written concerning the role of after-sales service in the promotion of and market development for household photovoltaic systems. This study examined the reliability of existing systems and people's perception of after-sales service.

The results of the study confirm that a significant market exists in the remote provinces of China for electricity. The details are provided in the following chapters. In chapter 2, the provinces and the methods used to conduct the market study are described. Following that, chapter 3 describes the survey population, along with their awareness and use of renewable energy. Chapter 4 presents an analysis of a special sample of households that currently use renewable energy, mainly to determine the characteristics of those that have adopted the technology. Chapter 5 discusses the implications of this study for the development of the renewable energy in the four provinces. 



\section{BACKGROUND ON AREAS TARGETED BY THE SURVEY}

This chapter provides a description of the local conditions in rural areas where many people have no access to grid electricity services in the provinces of Gansu, Inner Mongolia, Qinghai, and Xinjiang. A World Bank/GEF project for photovoltaic systems will be undertaken in these remote provinces of China. ${ }^{2}$

\section{BACKGround ON Provinces In STUdy}

The provinces covered in this report are located in some of the most remote areas of China, mainly in the north and northwestern part of the country. The provinces include Gansu, Inner Mongolia, Qinghai, and Xinjiang (see map IBRD 30439 at the back of this report). These 4 provinces cover an area of 4 million square kilometers, with a total of 18 million households (70.4 million people) living in the rural areas. The vast majority (approximately 83 percent) of these people already have access to some form of grid electricity. ${ }^{3}$ The remaining 17 percent of the rural population in these four provinces live in the more remote, isolated rural areas where extending grid electricity is both difficult and expensive.

The four provinces or autonomous regions are characterized by large land areas relative to population (see Table 2.1). Density of rural households and rural income levels are much lower than the national average. Three of the four areas also have large minority populations, especially target areas of the survey. Two of the provinces are autonomous regions, which means that a significant share of the population is of non-Han nationality. In Inner Mongolia, the largest single ethnic minority is Mongolian, while in Xinjiang it is Uigur. In Qinghai, the majority ethnic population is Tibetan, since much of the territory was once part of Tibet.

2 The project area was later expanded to include Tibet and Western Sechuan.

3 These households have access to either national-regional or mini and isolated grid electricity. 
Table 2.1: Socioeconomic Characteristics of Four Provinces in Survey, 1997

\begin{tabular}{|c|c|c|c|c|c|}
\hline & National & Gansu & $\begin{array}{c}\text { Inner } \\
\text { Mongolia }\end{array}$ & Qinghai & Xinjiang \\
\hline $\begin{array}{l}\text { Land area (thousands } \\
\text { ofsquare kilometers) }\end{array}$ & 9,600 & 450 & 1,100 & 720 & 1,600 \\
\hline Population (millions) & 1,236 & 24.9 & 22.6 & 5.0 & 17.2 \\
\hline $\begin{array}{l}\text { Density (persons per } \\
\text { square kilometer) }\end{array}$ & 129 & 55 & 21 & 7 & 11 \\
\hline $\begin{array}{l}\text { Rural per capita net } \\
\text { income (yuan) }\end{array}$ & 2,090 & 1,185 & 1,602 & $1,320.63$ & 1,500 \\
\hline Han nationality (\%) & 94 & 43.5 & 79.6 & 41.6 & 38.4 \\
\hline Minority (\%) & 6 & 56.5 & 20.4 & 58.4 & 61.6 \\
\hline $\begin{array}{l}\text { Main agricultural } \\
\text { products }\end{array}$ & & $\begin{array}{l}\text { Grain, cotton, } \\
\text { oil-bearing } \\
\text { plants, pigs, } \\
\text { sheep wool, } \\
\text { poultry, and } \\
\text { eggs }\end{array}$ & $\begin{array}{l}\text { Grain, oil- } \\
\text { bearing plants, } \\
\text { sugar beets, } \\
\text { pigs, cattle, } \\
\text { sheep, goats, } \\
\text { wool, and } \\
\text { cashmere }\end{array}$ & $\begin{array}{l}\text { Grain, oil- } \\
\text { bearing plants, } \\
\text { sugar beets, } \\
\text { pigs, cattle, } \\
\text { yaks, sheep, } \\
\text { goats, wool, } \\
\text { and cashmere }\end{array}$ & $\begin{array}{l}\text { Grain, oil- } \\
\text { bearing plants, } \\
\text { sugar beets, } \\
\text { pigs, cattle, } \\
\text { sheep, goats, } \\
\text { horses, camels, } \\
\text { wool, } \\
\text { cashmere, and } \\
\text { milk products }\end{array}$ \\
\hline
\end{tabular}

Source: China Statistical Yearbook, 1998.

The areas covered by the survey are also characterized by different geographic conditions - mainly mountains, basins, and plateaus. At the western edge of Xinjiang, the targeted area contains huge differences in elevation, from 4,000-5,000 meters at the western edge, to the Tarim Basin area, much of which is desert. The Qinghai-Tibet Plateau, known as the roof of the world, towers in the southwest at more than 4,000 meters. The Gansu corridor, a narrow 1,000 kilometer corridor where the Qinghai-Tibet, Loess, and Inner Mongolian Plateaus join, was part of the ancient Silk Road leading to Xinjiang and areas to the west. In the east, the terrain of Inner Mongolia ranges from mountains with dense forests in the northeast to the vast Hulunbuer Plateau for grazing in the center, with the rest of the area containing numerous deserts, sands, salt and alkali lakes, and scattered highlands.

\section{Current Photovoltaic System Business}

Despite the remoteness of these areas, photovoltaic businesses have been growing in the provinces. During the last five years, several different types of companies have been selling photovoltaic systems mainly centered in Qinghai. These companies are those that have grown from research institutes, larger ones that assemble photovoltaic systems 
for many applications (including telecommunications) and that may also produce photovoltaic modules, and other commercial companies like television manufacturers and small wind turbine manufacturers.

The companies selling photovoltaic systems typically involve three different types of operations. The businesses include urban-based distributors that procure major components from manufacturers and purchase locally minor components themselves, small assembly shops that sell systems and components of systems to system installers, and retailers that sell systems directly to end users. Some companies have their own retail networks, selling mainly through these established channels. There are also a few vertically integrated suppliers that have their own manufacturing facilities for key components, including modules and controllers. Although sales of photovoltaic home systems have increased steadily in recent years, none of these companies has a welldeveloped retail network.

During the past five years, photovoltaic system sales in these provinces have increased dramatically. The businesses in some provinces started out as partially owned by the state, and sold systems with significant subsidies. Recently, however, many of the subsidies have been reduced or eliminated, and many new smaller companies have emerged that are dedicated to selling renewable energy systems on a commercial basis. These smaller, privately owned companies have entered the market focusing on the smaller systems that are more affordable to their customers. Although such companies have a comparative cost disadvantage because of small-scale operations and low-volume production, they have been cutting costs to compete. The emphasis on smaller systems and cutting costs is a common strategy employed by photovoltaic companies to make systems more affordable and marketable to a larger segment of the population.

The photovoltaic market is increasingly competitive. Sales data collected from photovoltaic companies indicate that in 1997, the largest 4 companies held 51 percent of the market in unit sales, 31 percent of market in watt power sales, and 36 percent of the market in sales revenue. In 1997, the top four ranked companies in terms of photovoltaic system sales revenue all were registered during the past three years. The company with the largest market share increased the number of photovoltaic units sold from 3,500 in 1995 to about 7,500 units in 1997. Most of the units were the 20-watt systems, and were sold to customers in Gansu, Qinghai, Sichuan, and Tibet.

The photovoltaic market is likely to remain competitive in the near future because the start-up capital requirements are small, with little investment required in equipment, buildings, and vehicles. Also, the technology required to put systems together is also relatively simple and widely available. Presently, there are no dominant brands, and the companies compete based on their product presentation and promises of quality, performance, and customer convenience. 


\section{Description of Typical Photovoltaic Systems USEd in RuRal Areas in China}

Photovoltaic systems are typically used by individual households, and commercial and small industrial establishments to provide electricity in areas where there is no grid electricity. A typical photovoltaic system is made up of a photovoltaic panel, battery, and a battery or load controller. For individual home usage, a photovoltaic system is typically used to power two to four indoor lights, an outdoor security light, and a television set or a radio-cassette. The most common systems used in the four targeted provinces and elsewhere in the country are 10 and 20-watt photovoltaic systems. The systems can power two lights and a radio-cassette for four hours. A small number of larger photovoltaic systems are also being sold. They include a 50- and 75-watt photovoltaic array. A photovoltaic system can be upgraded by adding additional panels. With an upgrade to 75 watts, the photovoltaic system will enable users to operate a color television.

In China, the panel and the other components are usually packaged in two selfcontained wooden boxes. Two lights are usually included in the box, and the system wiring is complete. The user simply needs to set the panel in place and connect the battery to the panel in order to be ready to start operation.

\section{BRIEF DESCRIPTION OF THE STUDY DESIGN}

The findings presented in this report are based on a field survey and interviews of 2,886 rural households who live in villages without access to grid electricity in the provinces of Gansu, Inner Mongolia, Qinghai, and Xinjiang (see Appendix B for the details of the methods and sample design). The surveys were conducted during August and September $1998 .{ }^{4}$ Out of 2,886 cases selected through the random sampling process, 111 homeowners had photovoltaic systems, and 439 had small wind systems. A supplemental sample also was collected for households that use photovoltaic systems. The rationale for purposely selecting households that use photovoltaic systems was to help the study develop a profile of households using these systems in the region of the study. For this purpose, an additional 27 households that own photovoltaic household systems were interviewed during the course of the project.

The goal of the study, as discussed earlier, was to profile the potential market for photovoltaic systems that can provide electricity to rural households. Because so many households had electricity or were near electricity distribution systems, it made little sense to draw the sample from the provincial population. More than 80 percent of households in the selected provinces already have electricity service from grid systems. Households in counties with extensive rates of household electrification are less likely to adopt photovoltaic systems. The grid systems in China provide higher levels of electricity

\footnotetext{
${ }^{4}$ The only exception is the survey in Abagaqi County in Inner Mongolia (a total of 90 cases), which was conducted in April 1999.
} 
service, and the price for electricity is very low. The few consumers without electricity in these counties may opt to wait for grid electricity, instead of buying a photovoltaic system.

As a consequence, the target population or population frame for the market survey consists of those households living in villages without grid electricity, and in the counties in which at least 15 percent of villages are without electricity. ${ }^{5}$ The population frame and the sample population are illustrated in Map IBRD 30439 at the end of this report. For the four provinces, about 1.4 million households are in such counties with an electrification rate of less than 85 percent (see Tables 2.2 and B-2 for details). Only 270,000 households without electricity are in the counties that are not in the sample frame of this study. Thus, the population universe in the study-the households in villages without electricity-are well represented by the counties that have the lowest penetration rate for grid electricity systems.

Table 2.2: Households without Electricity in Counties and Provinces

\begin{tabular}{lccccc}
\hline & Gansu & $\begin{array}{c}\text { Inner } \\
\text { Mongolia }\end{array}$ & Xinjiang & Qinghai & Total \\
\hline $\begin{array}{l}\text { Total number of rural households in counties } \\
\text { with: }\end{array}$ & $4,169,218$ & $2,753,990$ & $2,248,512$ & 493,414 & $9,665,134$ \\
Electricity rate greater than 85\% & $2,301,491$ & $1,963,192$ & 504,265 & 318,916 & $5,087,864$ \\
Electricity rate less than 85\% & $1,867,727$ & 790,798 & $1,744,247$ & 174,498 & $4,577,270$ \\
\hline $\begin{array}{l}\text { Total number of rural households without } \\
\text { electricity in counties with: }\end{array}$ & 693,542 & 383,367 & 459,956 & 104,052 & $1,640,917$ \\
$\quad$ & 121,637 & 87,011 & 43,735 & 19,348 & 271,731 \\
$\quad \begin{array}{l}\text { Electricity rate greater than 85\% } \\
\text { Electricity rate less than 85\% }\end{array}$ & 571,905 & 296,356 & 416,221 & 84,704 & $1,369,186$ \\
\hline
\end{tabular}

Source: CRED 1998.

\section{CONCLUSION}

The sample of households in the region without electricity should be representative of the possible market for household photovoltaic systems. For the four provinces, the population universe of the sample covers more than 90 percent of the

\footnotetext{
5 The 15 percent cutoff point was chosen based on the average 17 percent of households without electricity in the combined 4 provinces.
} 
households without electricity in the provinces. The sample covers some of the most isolated and poorest areas of China. In the chapters that follow, details of the socioeconomic characteristics of the households without electricity access are described in detail. 


\section{SURVEY RESULTS: SOCIOECONOMIC CHARACTERISTICS OF HOUSEHOLDS WITHOUT ELECTRICITY}

The purpose of this chapter is to understand the characteristics of the households in the areas without electricity in the four provinces. This provides a background for identifying the characteristics of households that would be most likely to purchase or lease household photovoltaic systems. For instance, one goal of the study was to ascertain whether incomes in such areas are high enough to make such systems affordable. Another issue is whether households are familiar with or have access to credit to purchase photovoltaic systems. These and other issues are the topic of this chapter.

\section{INCOME, OCCUPATION, AND EDUCATION}

The income and occupations in the four provinces are quite diverse. For instance, Gansu is an extremely poor province composed of poor farmers. This province has long been considered one of the poorest in China. More than 90 percent of the households without electricity in Gansu earn their living as farmers (see Table 3.1), but they produce very little income. The incomes in areas of Gansu that were in the survey are about Y 200 or about $\$ 25$ per family per month, which is close to 6 times lower than in Inner Mongolia. In the year before the survey, a severe drought in Gansu may have affected incomes. Because of the drought, it may be possible that farmers consumed most, if not all, of the food they grew during this period, with very few cash sales of crops. Even without the drought, however, Gansu is a very poor area.

The rural households in Inner Mongolia have the highest income of the four provinces (see Table 3.1). Just over 60 percent of the households living in areas without electricity in Inner Mongolia are herders. The income of the herders is close to 10 times higher compared to farmers in this same province, illustrating that herding is a good occupation for people in the area. The average income of the herders is more than $\mathrm{Y}$ 2,000 per household or $\$ 250$ per month. Within China, the demand for the meat products produced by herders has been increasing, especially in urban areas.

Qinghai has an even higher percentage of herders than Inner Mongolia. More than three-quarters of the populations living in areas without access to electricity in Qinghai are herders, and only 10 percent of the populations are farmers. The herders in Qinghai, however, do not earn as much income as those in Inner Mongolia. They earn about Y 675 per household per month. 
Table 3.1: Household Monthly Income by Type of Occupation of Household Head

\begin{tabular}{lrrrrr}
\hline & Gansu & $\begin{array}{c}\text { Inner } \\
\text { Mongolia }\end{array}$ & Xinjiang & Qinghai & Total \\
\hline Farmer (yuan) & 200 & 167 & 759 & 300 & 365 \\
Population represented & 515,829 & 96,651 & 266,604 & 9,255 & 890,338 \\
Percent within province & 90 & 33 & 64 & 11 & 65 \\
Herdsman (yuan) & - & 2,121 & 610 & 673 & 1410 \\
Population represented & - & 180,319 & 98,732 & 66,724 & 345,778 \\
Percent within province & - & 61 & 24 & 79 & 25 \\
Mixed herding farming & 288 & 230 & 645 & 326 & 428 \\
(yuan) & & & & & \\
Population represented & 26,592 & 10,995 & 31,300 & 8,520 & 77,407 \\
Percent within province & 5 & 4 & 7 & 10 & 6 \\
Local TVE worker (yuan) & 298 & - & 836 & - & 493 \\
Population represented & 5,418 & - & 3,078 & - & 8,496 \\
Percent within province & 0.9 & - & 0.7 & - & 0.6 \\
Outside TVE worker (yuan) & 183 & 198 & - & - & 183 \\
Population represented & 10,753 & 192 & - & - & 10,945 \\
Percent within province & 2 & 0.1 & - & - & 0.8 \\
Local manager (yuan) & 345 & 390 & 594 & - & 423 \\
Population represented & 2,591 & 1,844 & 1,539 & - & 5,974 \\
Percent within province & 0.5 & 0.6 & 0.4 & - & 0.4 \\
Retired (yuan) & 500 & 1,711 & 1,064 & - & 1,157 \\
Population represented & 184 & 603 & 2,300 & - & 3,086 \\
Percent within province & - & 0.2 & 0.6 & - & 0.2 \\
Other (yuan) & 378 & 575 & 642 & 866 & 529 \\
Population represented & 10,539 & 3,018 & 12,180 & 205 & 25,943 \\
Percent within province & 2 & 1 & 3 & 0.2 & 2 \\
\hline All households (yuan) & 208 & 1,370 & 713 & 598 & 637 \\
Population represented & 571,905 & 295,622 & 415,733 & 84,704 & $1,367,964$ \\
Percent within province & 100 & 100 & 100 & 100 & 100 \\
\hline Note: & & & & & - \\
\end{tabular}

Note: This table presents the weighted results of the sample survey. The average income of all households classified by type of occupation of household is slightly different from the average income of all households because there are a few cases with missing values for type of occupation. The "__" indicates zero income. TVE stands for township and village enterprise.

Source: China Market Survey 1998.

Xinjiang is predominately composed of farming areas. As opposed to Gansu, the average farmer in Xinjiang has a higher income than the average herding family in the same province. Their income is about two and a half to almost five times higher than farmers in three other provinces. The distribution of household income among different occupations within the province is more homogeneous than in three other provinces. The reason for this is probably that the farming in Xinjiang is very different than in Gansu. Xinjiang produces high-value cash crops, such as grapes and melons, as opposed to the grain, cotton, and oil-bearing plants grown in Gansu.

The education levels in the provinces are very high for such remote areas. Only one out of the four provinces has very low levels of education. Among the four provinces, 
the rural households in the areas without electricity in Qinghai have the lowest educational levels. More than half of the heads of households surveyed cannot read or have never attended school, and most of the people who had attended school have only a primary school level of education. Furthermore, in about a third of rural households without electricity in Qinghai, they are illiterate or they have never attended school, or both. In the other three provinces, only 7-12 percent of the heads of households are illiterate or have never attended school. Only 1-4 percent of the households in the three provinces are illiterate.

The conclusion is that the provinces differ significantly in terms of both income and occupation. The average incomes in the provinces range from a low of about Y 200 in Gansu to more than Y 1,300 in Inner Mongolia. The percentage of herders range from almost none in Gansu to more than three-quarters of the population in Qinghai. This clearly illustrates that there are likely to be very differing markets in each of the provinces, based on relative incomes and quite different occupations.

\section{Value of RuRal Household Assets}

In provinces with large herding populations, income could be a misleading indicator of ability to pay for renewable energy systems. Herders may or may not have income, depending on when they sell their livestock. As opposed to agricultural crops that are harvested on an annual basis, livestock can be sold over a period of years. Herds are a very liquid asset, and can be considered a form of savings. As a consequence, this study has also estimated the assets of the rural households, in order to supplement the information on family income (see Table 3.2). The value of all livestock owned determines the total assets for the rural households in this study. ${ }^{6}$ The idea for computing this value was to see whether the income of farmers and herders was an adequate measure of the ability to purchase renewable energy systems. Although this is not a true measure of total assets, realistically herders or farmers can sell livestock to raise money to purchase consumer goods. ${ }^{7}$ Hence, it is an appropriate measure for the purposes of this study.

In general, farm households are much poorer than herders in the region of the study. It should be remembered that these are farms in very remote areas, where

\footnotetext{
${ }^{6}$ The value of livestock is calculated from the amount of livestock owned at the time of survey and the price at which the household sold livestock the year before the survey.

${ }^{7}$ In China, land is still considered property of the state, although people have the right to use it, and these rights can be bought or sold. Because of the remoteness of these counties, however, land is not bought or sold as often or, when land is bought or sold, it is typically for agricultural uses and not for commercial or other uses. As a result, the price of the land is generally determined by an amount of money that can be derived or generated from agricultural activities.
} 
agricultural land is poor. The only exception is in Xinjiang, where farmland is more productive than in the other three provinces. ${ }^{8}$

\footnotetext{
${ }^{8}$ Farmland in Xinjiang is used to grow higher-priced fruit, such as melons and grapes.
} 


\section{Table 3.2: Average Value of Livestock Classified by Occupation of Head of Household and Type of Asset}

\begin{tabular}{|c|c|c|c|c|c|}
\hline & Gansu & $\begin{array}{c}\text { Inner } \\
\text { Mongolia }\end{array}$ & Xinjiang & Qinghai & Total \\
\hline \multicolumn{6}{|l|}{ Occupation } \\
\hline Farmer (yuan) & 3,002 & 4,361 & 5,421 & 1,727 & 3,865 \\
\hline Population represented & 513,373 & 98,651 & 266,109 & 9,255 & 887,378 \\
\hline Herdsman (yuan) & .. & 80,792 & 28,416 & 63,664 & 62,583 \\
\hline Population represented & .. & 180,319 & 98,211 & 66,681 & 345,212 \\
\hline Herdsman and farmer (yuan) & 7,092 & 5,065 & 14,063 & 22,792 & 11,329 \\
\hline Population represented & 26,592 & 10,995 & 30,681 & 8,520 & 76,788 \\
\hline Local TVE worker (yuan) & 565 & .. & 5,712 & .. & 2,429 \\
\hline Population represented & 5,418 &.. & 3078 & .. & 8,496 \\
\hline Outside TVE worker (yuan) & 643 & 1529 & .. & .. & 659 \\
\hline Population represented & 10,753 & 192 & .. & .. & 10,945 \\
\hline Local manager (yuan) & 859 & 21,032 & 10,510 & .. & 9,572 \\
\hline Population represented & 2,591 & 1,844 & 1,539 & .. & 5,974 \\
\hline Retired (yuan) & 553 & 59,549 & 10,707 & .. & 19,648 \\
\hline Population represented & 184 & 603 & 2,300 & .. & 3,086 \\
\hline Other (yuan) & 3,536 & 11,921 & 2,137 & 72,996 & 4,404 \\
\hline Population represented & 10,539 & 3,018 & 12,180 & 205 & 25,943 \\
\hline \multicolumn{6}{|l|}{ Total } \\
\hline Average value of all livestock & 3,124 & 51,382 & 11,458 & 52,802 & 19,213 \\
\hline $\begin{array}{l}\text { All households (population } \\
\text { represented) }\end{array}$ & 569,449 & 296,356 & 414,586 & 84,662 & $1,365,053$ \\
\hline
\end{tabular}

.. Negligible.

Note: Because of the missing values of variables representing type of occupation, there are slight differences in total number of population represented and the summation of population represented by types of occupation. TVE stands for township and village enterprise.

Source: China Market Survey 1998.

Most farmers in these areas are very poor. Both the evidence based on income and the proxy evidence based on assets confirm that the herders in the region are wealthier than farmers. Thus, the herders have an advantage of both income and assets over the poor farmers in these areas, which this is relevant in terms of their ability to pay for renewable energy systems. 


\section{EXPERIENCE WITH BANKING AND CREDIT}

The availability of credit in remote areas is often very poor. The purchase of photovoltaic systems without credit requires households to have Y 1,000-2,000 in hand, and most agree that this can be a major stumbling block to the promotion of systems. The availability of credit for the purchase of photovoltaic systems can expand the market by lowering the initial cash outlays for the systems. Because availability of credit is often considered a major barrier to the adoption of photovoltaic systems, one goal of the survey was to determine the experience of rural households with making purchases on credit. Today most purchases of renewable energy systems are on a cash basis. This chapter explores the extent of households' credit experience, along with their attitude toward and preference for using credit to purchase photovoltaic systems.

Many people in these areas are familiar with credit. Between 30 and 40 percent of the households in three of the provinces already have experience with taking credit from rural banks, credit unions, or other sources (Table 3.3). The province with the lowest participation in credit markets is Qinghai, where slightly less than 10 percent of rural households reported taking a loan.

As will be seen later in this chapter, most of the loans are taken for business purposes. Thus, to a certain degree, the length and the type of the loan conform to what might be expected of a small business loan for purchasing seasonal inputs for farming or herding. The average length of a loan is about one year for the three provinces with the highest percentage of borrowers. As the survey reveals, about 80 to 90 percent of borrowing households took their loans in 1997 and 1998. The amount of the loan is relatively small, ranging from Y 1,000-4,000 (\$125-500). Most of the money was borrowed either from a bank or a credit union. In fact, credit unions are the most common source of loans in the area of the study. The main exception to this trend was in Inner Mongolia and Qinghai, where more people are dependent on informal credit. For Inner Mongolia and Qinghai, neighbors and relatives account for about a quarter of all loans taken by rural households in these two provinces. 
Table 3.3: Household Borrowing Patterns in Villages without Electricity in Four Provinces

\begin{tabular}{lcccc}
\hline & Gansu & $\begin{array}{c}\text { Inner } \\
\text { Mongolia }\end{array}$ & Xinjiang & Qinghai \\
\hline $\begin{array}{l}\text { Credit experience (\% of } \\
\text { households) }\end{array}$ & 30 & 29 & 43 & 10 \\
$\begin{array}{l}\text { Average loan amount (yuan) } \\
\text { Average length of loan (months) }\end{array}$ & 1,253 & 4,210 & 2,388 & 1,858 \\
Year of last loan taken (\% of & 15 & 12 & 13 & 22 \\
$\quad$ households with loan) & & & & \\
1998 & 46 & 15 & 57 & 25 \\
1997 & 34 & 76 & 26 & 53 \\
1996 & 8 & 4 & 8 & 19 \\
$\quad$ Before 1996 & 11 & 5 & 9 & 3 \\
Source of loan (\% of households & & & & \\
$\quad$ with loan & 28 & 13 & 38 & 7 \\
$\quad$ Bank & 70 & 58 & 47 & 51 \\
$\quad$ Credit union & 2 & 18 & 8 & 26 \\
$\quad$ Relatives &. & 5 & 2 & 1 \\
$\quad$ Neighbor &.. & 6 & 5 & 15 \\
$\quad$ Others & & &
\end{tabular}

.. Negligible.

Source: China Market Survey, 1998.

Most of the borrowing in rural areas is for business activities, which include farming and herding. Many of these loans are for purchasing inputs necessary for these activities. Farmers have seasonal needs for credit, and herders sometimes need to purchase fodder for their livestock. The loans taken out for such purposes range from one-half to two-thirds of all loans (Table 3.4). The remainder of the loans is spread evenly among a wide variety of purposes, including purchasing food, health care, house repairs, and others. Very few households have borrowed money to buy appliances. This may be because banks or credit unions in rural areas do not typically finance this type of loan. Consumers may also be somewhat conservative in taking out loans that do not generate income for them. The reason for this is that productive activities produce income that will enable the household to repay the loan. 
Table 3.4: Household Use of Loans in Villages without Electricity in Four Provinces (percent)

\begin{tabular}{lccccc}
\hline Use of loan & Gansu & $\begin{array}{c}\text { Inner } \\
\text { Mongolia }\end{array}$ & Xinjiang & Qinghai & Total \\
\hline Buy food & 4.9 & 2.0 & 10.9 & 23.7 & 7.1 \\
$\begin{array}{l}\text { Build, expand, or repair } \\
\text { house }\end{array}$ & 7.4 & 4.1 & 3.5 & 4.7 & 5.1 \\
Health care & 14.9 & 12.1 & 9.6 & 5.6 & 12.0 \\
Business & 63.6 & 64.6 & 64.4 & 52.4 & 64.0 \\
Buy equipmentor appliances & 2.0 & 3.6 & 4.3 & 5.2 & 3.3 \\
Important family activities, & 5.5 & 4.1 & 3.4 & 3.6 & 4.3 \\
for example, marriages and & & & & & \\
funerals & 1.8 & 9.4 & 3.8 & 4.8 & 4.2 \\
Others & 100 & 100 & 100 & 100 & 100 \\
\hline Total & & & & & \\
\hline
\end{tabular}

*Includes buying fodder and grass.

Source: China Market Survey 1998.

Another issue relevant to market development for renewable energy is the income of households that typically borrow money in rural areas. Households that have borrowed money have lower incomes than households who have not borrowed money (see Table 3.5). The only exception to this pattern is in Xinjiang, where people who borrow money have higher incomes compared with those who do not borrow money.

Table 3.5: Comparison of Income and Value of Livestock between Households that Have Not and Have Taken a Loan Before

\begin{tabular}{|c|c|c|c|c|c|c|}
\hline \multicolumn{2}{|c|}{$\begin{array}{l}\text { Whether households have taken } \\
\text { any loan before }\end{array}$} & \multicolumn{2}{|r|}{ Inner } & Xinjiang & Qinghai & Total \\
\hline \multirow[t]{3}{*}{ No } & Income & 199 & 1,610 & 574 & 644 & 667 \\
\hline & Livestock value & 3,411 & 62,807 & 13,201 & 55,310 & 23,966 \\
\hline & Percent of household) & 70 & 71 & 57 & 90 & 67 \\
\hline \multirow[t]{3}{*}{ Yes } & Income & 157 & 514 & 950 & 337 & 556 \\
\hline & Livestock value & 2,829 & 20,758 & 10,063 & 21,594 & 9,619 \\
\hline & Percent of household) & 30 & 29 & 43 & 10 & 32 \\
\hline \multicolumn{2}{|c|}{ Total } & 186 & 1296 & 735 & 614 & 631 \\
\hline \multicolumn{2}{|c|}{ Total livestock value } & 3,233 & 50,760 & 11,857 & 52,025 & 19,251 \\
\hline \multicolumn{2}{|c|}{ Households represented (valid N) } & 490,425 & 270,408 & 381,514 & 64,249 & $1,206,596$ \\
\hline
\end{tabular}

Source: China Market Survey 1998.

Rural lending institutions lend money for productive uses, such as inputs to farming or for raising livestock. Although households are very likely to borrow money for 
such purposes, there is no certainty that they will borrow money for photovoltaic systems that result mainly in improving the quality of life for rural households.

\section{CURRENT ENERGY USE AND EXPENDITURE FOR HOUSEHOLd Lighting}

An understanding of existing energy use and expenditure patterns for lighting is very important for determining the potential willingness or ability to pay for better lighting services. Generally, surveys of rural households reveal that all households use some form of lighting during the evening hours. Although the lighting may be used for short periods, and it may be of poor quality, all households use it. Given the poor light given off by most nonelectric forms of lighting, the expenditures on lighting can often be considered a minimum willingness or ability to pay.

Similar to elsewhere in the developing world, the major sources of energy for lighting for rural households living in villages with no access to grid electricity are kerosene lamps for general use, flashlights for task-specific and mobile purposes, and to some extent candles (see Table 3.6). Although present in all households, kerosene, diesel, and gasoline lamps are the most common in lower-income rural households. In the lowest income groups, more than 90 percent of households rely on petroleum lamps. For the higher-income groups, this figure declines modestly until the highest income group, in which only about one-fifth of the population use these lamps.

A high percentage of households in Inner Mongolia area are getting light from electricity produced by renewable energy sources. Approximately 57 percent of rural households in villages with no access to grid electricity in Inner Mongolia are using small wind systems. Such systems are an especially important option for herders. Wind systems were introduced with strong government support during the last two decades. The herders actually fold up these systems and take them when they move from one grazing area to another. Outside Inner Mongolia, there is not much use of wind systems. As might be expected, the higher-income groups in the province are the primary purchasers of wind generators.

During the past few years photovoltaic home systems have been introduced to rural households in these four provinces. Considerable success has been achieved in reaching remote rural populations in Qinghai, where about 9 percent of rural households in survey areas own small photovoltaic home systems. Also, rapidly increasing sales of photovoltaic systems are also reported in Tibet and Sichuan, which border Qinghai and share its cultural characteristics in these border areas. Qinghai is a province in which retailers have been most active in promoting photovoltaic home systems. Only a limited number of households in the other three provinces still use photovoltaic systems. 
Table 3.6: Household Energy Use for Lighting by Income Class (percent of households within group)

\begin{tabular}{|c|c|c|c|c|c|c|c|c|}
\hline & $\begin{array}{l}\text { Candles } \\
\text { or butter }\end{array}$ & $\begin{array}{c}\text { Kero- } \\
\text { sene, } \\
\text { diesel, or } \\
\text { gasoline }\end{array}$ & $\begin{array}{l}\text { Dry cell } \\
\text { batteries }\end{array}$ & $\begin{array}{l}\text { Small } \\
\text { genera- } \\
\text { tor sets }\end{array}$ & $\begin{array}{c}\text { Small } \\
\text { wind } \\
\text { systems }\end{array}$ & $\begin{array}{c}\text { Small } \\
\text { hybrid } \\
\text { systems }\end{array}$ & $\begin{array}{l}\text { PV home } \\
\text { systems }\end{array}$ & $\begin{array}{c}\text { House- } \\
\text { holds } \\
\text { repre- } \\
\text { sented by } \\
\text { sample }\end{array}$ \\
\hline \multicolumn{9}{|l|}{$\begin{array}{l}\text { Income deciles } \\
\text { (yuan per month) }\end{array}$} \\
\hline$<51.67$ & 34.3 & 96.0 & 62.2 & 0.4 & 3.4 & .. & 0.0 & 139,141 \\
\hline $51.67-103.33$ & 24.8 & 90.5 & 74.4 & 0.5 & 7.3 & .. & 0.2 & 133,970 \\
\hline $103.34-155.83$ & 19.4 & 93.4 & 80.1 & 0.2 & 4.7 & .. & 0.0 & 136,474 \\
\hline $155.84-208.33$ & 33.4 & 93.9 & 85.0 & 0.4 & 3.6 & 0.2 & 0.5 & 135,461 \\
\hline $208.34-275.00$ & 27.3 & 93.6 & 78.5 & 2.0 & 4.2 & 0.0 & 0.8 & 141,926 \\
\hline $275.01-378.33$ & 26.7 & 82.5 & 80.4 & 1.3 & 7.5 & 0.1 & 1.5 & 133,824 \\
\hline $378.34-500.00$ & 40.3 & 84.8 & 79.0 & 2.2 & 4.8 & 0.1 & 0.8 & 137,781 \\
\hline $500.01-716.66$ & 52.6 & 71.1 & 87.9 & 5.3 & 10.6 & .. & 1.8 & 137,922 \\
\hline $\begin{array}{l}716.67- \\
1,275.00\end{array}$ & 62.1 & 56.2 & 89.8 & 10.2 & 23.7 & .. & 2.7 & 135,790 \\
\hline$>1,275.01$ & 81.4 & 18.9 & 95.5 & 20.5 & 62.4 & 0.5 & 2.2 & 136,898 \\
\hline \multicolumn{9}{|l|}{ Province } \\
\hline Gansu & 18.5 & 98.5 & 84.6 & 0.4 & 0.3 & .0 & .0 & 571,905 \\
\hline Inner Mongolia & 75.7 & 35.8 & 87.2 & 11.3 & 57.3 & 0.2 & 2.0 & 296,356 \\
\hline Xinjiang & 39.8 & 87.2 & 72.8 & 5.4 & 2.2 & .. & 0.1 & 416,221 \\
\hline Qinghai & 64.8 & 44.0 & 80.3 & 0.5 & 0.1 & 0.3 & 9.1 & 84,704 \\
\hline \multicolumn{9}{|l|}{ Occupation } \\
\hline Farmer & 27.3 & 93.6 & 77.4 & 2.4 & 1.9 & .. & 0.1 & 890,338 \\
\hline Herdsman & 75.7 & 35.1 & 95.3 & 9.9 & 45.5 & 0.2 & 3.5 & 345,775 \\
\hline $\begin{array}{l}\text { Herdsman and } \\
\text { farmer }\end{array}$ & 34.7 & 93.5 & 75.3 & 2.4 & 3.2 & 0.3 & 1.0 & 77,407 \\
\hline $\begin{array}{l}\text { Local TVE } \\
\text { worker }\end{array}$ & 23.7 & 86.7 & 51.7 & 3.0 & .. & .. & .. & 8,496 \\
\hline $\begin{array}{l}\text { Outside TVE } \\
\text { worker }\end{array}$ & 2.7 & 100.0 & 9.5 & .. & .. & .. & .. & 10,945 \\
\hline Local manager & 45.5 & 34.3 & 100.0 & .. & 18.6 & .. & .. & 5,974 \\
\hline Retired & 86.9 & 89.2 & 100.0 & .. & 10.8 & .. & .. & 3,086 \\
\hline Other & 42.0 & 71.6 & 74.0 & 3.1 & 9.0 & .. & 0.4 & 25,943 \\
\hline All households & 40.2 & 78.1 & 81.3 & 4.3 & 13.2 & 0.1 & 1.1 & $1,367,964$ \\
\hline
\end{tabular}

The source of lighting for rural households also varies according to income class. Electricity tends to be used among higher-income households. Only a small percentage of lower-income households use electricity from small electric generators, but about 10-20 
percent of households in the ninth and tenth income deciles use these sources of energy for electricity. Similarly, the percentage of households using small wind systems rises from only a few percent among the lowest income groups to more than half the population in the highest income group, which involves mainly households in Inner Mongolia. For small photovoltaic home systems, only 2 percent of the highest income group use photovoltaic systems for lighting. Although dry cell batteries are widely used by most households, the number of households that use them also increases among higher-income classes. This suggests that higher-income households are more dependent on electric lighting than others, and they are willing to pay a very high price for electricity from dry cell batteries.

The comparison of total monthly spending for lighting energy and electricity also reveals that households in Gansu, which is the poorest of all four provinces, spend the least on lighting. The total monthly spending for lighting of households in three other provinces, which also have higher income levels, is about three times more than households in Gansu Province (Figure 3.1). It should be noted that the relatively high monthly spending among households in Qinghai reflects the high market value of butter. In Qinghai, in spite of its high commercial value, butter produced from yak milk is used within the family for lighting and religious purposes, and only the butter that is left over is sold. 
Figure 3.1: Total Monthly Spending on Lighting Fuel in Energy and Electricity

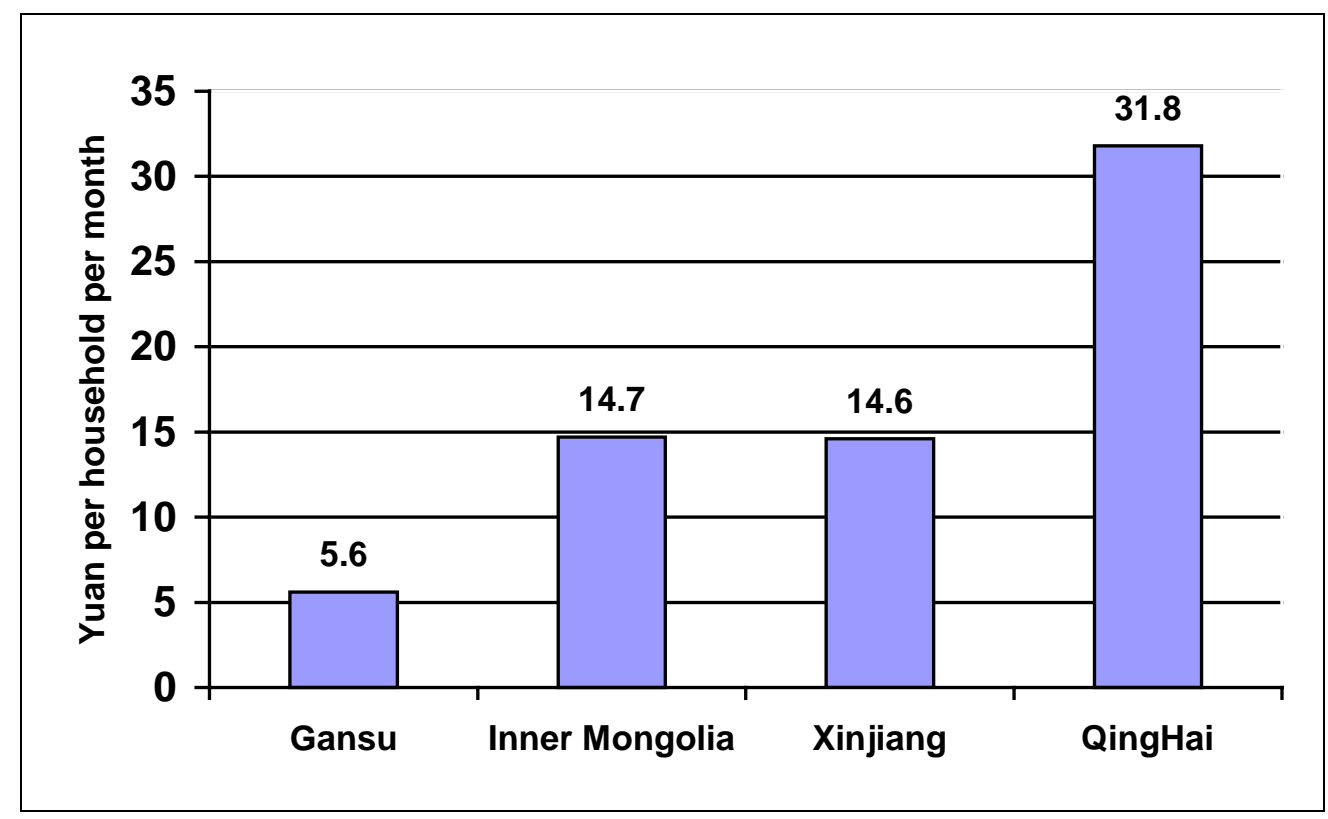

Note: High monthly expenses for households in Qinghai reflect the high opportunity cost of using butter for lighting. These figures do not contain the amortized costs of lighting equipment or generators.

Source: China Market Survey 1998.

Higher-income households spend much more than lower-income households on lighting services, and yet the amount they spend accounts for a smaller proportion of their income than lower-income counterparts. This is a pattern that is found in most developing countries (Figure 3.2). For these areas, the total amount of money spent for lighting energy and electricity is relatively low, ranging from only about Y 5-6 per month among the poorest households and reaching about Y 25 per month among the highest income groups. The poorest households in the region spend between 5 and 13 percent of their cash income on purchased energy for lighting. As indicated, this is mainly because of low incomes rather than because of significant cash outlays for energy. The higher-income group spends more on energy, but spend only about 1-3 percent of their income on it (see Table 3.7). It is interesting that these higher-income groups continue to spend similar levels of money on candles and kerosene, but in addition they spend more on batteries, and in the highest group on small generator sets. Renewable energy systems are purchased for cash, and do not account for any monthly expenses for fuel.

Figure 3.2: Total Monthly Spending on Lighting Energy and Electricity 
(energy expenses in yuan and expenses as percentage of income)
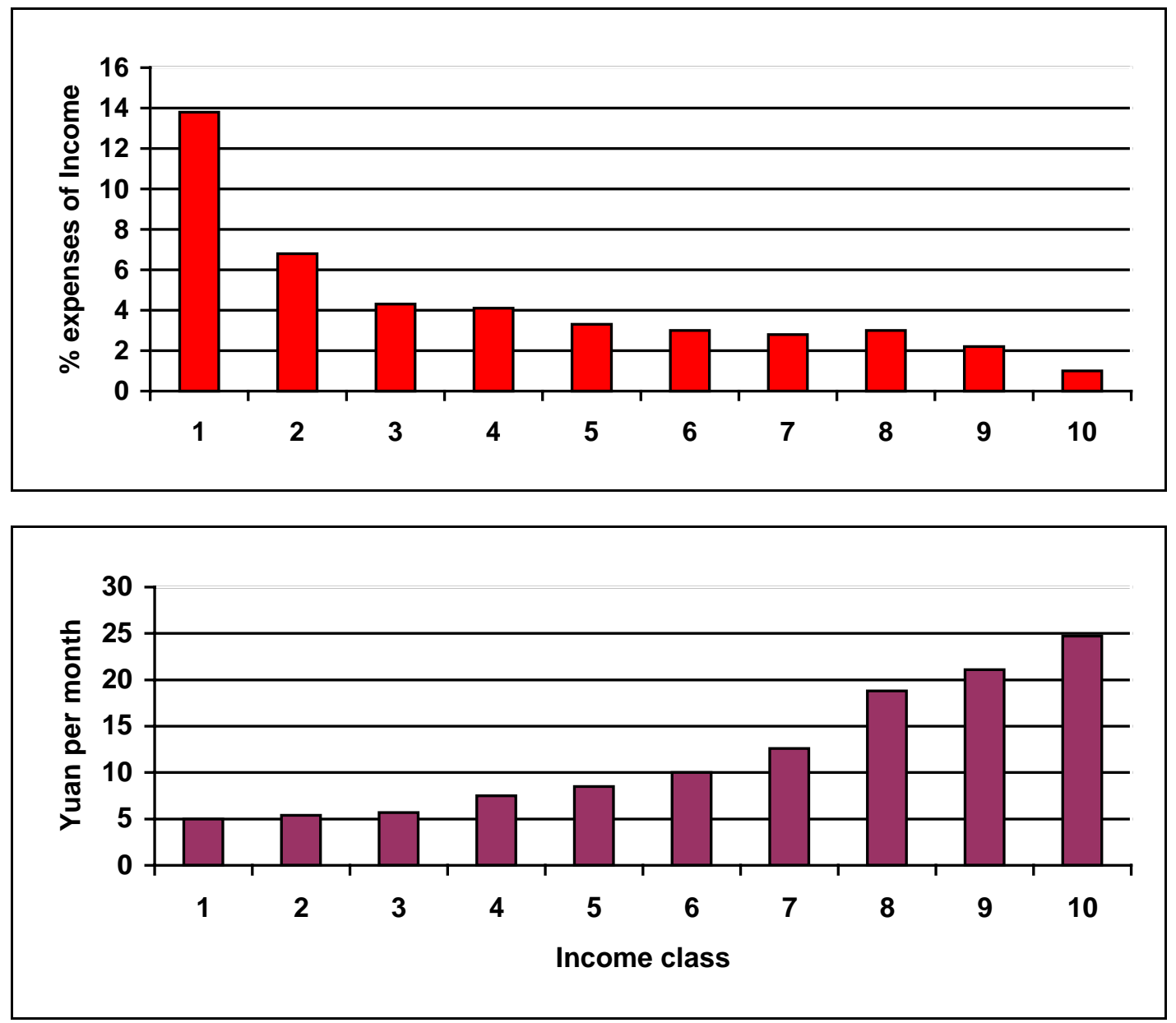

Note: Income groups are the same as in Table 3.6.

Source: China Market Survey 1998.

The expenditure patterns for lighting services also vary significantly among herders and farmer households. About 45 percent of all herders use small wind systems compared with only 2 percent of farming households (see Table 3.6). Also, about onetenth of all herdsman households get electricity for lighting from a small electric generator or from a community grid. Almost 4 percent of all herdsman households own photovoltaic home systems, while almost no farmer households own them. Herders also spend more for lighting energy and electricity than farmer households. 
Table 3.7: Household Monthly Spending for Lighting Energy

\begin{tabular}{|c|c|c|c|c|c|c|}
\hline & $\begin{array}{c}\text { Candle or } \\
\text { butter }\end{array}$ & $\begin{array}{l}\text { Kerosene, } \\
\text { diesel, or } \\
\text { gasoline }\end{array}$ & $\begin{array}{l}\text { Dry cell } \\
\text { batteries }\end{array}$ & $\begin{array}{c}\text { Small } \\
\text { generator } \\
\text { set }\end{array}$ & $\begin{array}{c}\text { Total } \\
\text { spending }\end{array}$ & $\begin{array}{l}\text { As \% of } \\
\text { income }\end{array}$ \\
\hline \multicolumn{7}{|l|}{$\begin{array}{l}\text { Income (yuan per } \\
\text { month) }\end{array}$} \\
\hline$<51.67$ & 0.67 & 3.12 & 1.20 & 0.06 & 5.06 & 13.7 \\
\hline $51.67-103.33$ & 0.65 & 3.28 & 1.40 & 0.03 & 5.38 & 6.8 \\
\hline $103.34-155.83$ & 0.68 & 3.53 & 1.47 & 0.02 & 5.69 & 4.4 \\
\hline $155.84-208.33$ & 1.00 & 4.06 & 2.35 & 0.05 & 7.48 & 4.1 \\
\hline $208.34-275.00$ & 1.50 & 3.88 & 2.29 & 0.76 & 8.46 & 3.3 \\
\hline $275.01-378.33$ & 2.69 & 4.43 & 2.74 & 0.21 & 10.07 & 2.9 \\
\hline $378.34-500.00$ & 4.15 & 5.05 & 2.79 & 0.53 & 12.64 & 2.8 \\
\hline $500.01-716.66$ & 7.58 & 4.88 & 4.82 & 1.51 & 18.78 & 3.0 \\
\hline $716.67-1,275.00$ & 5.94 & 5.26 & 5.69 & 4.21 & 21.13 & 2.2 \\
\hline$>1,275.01$ & 5.97 & 2.39 & 9.00 & 7.31 & 24.69 & 1.0 \\
\hline \multicolumn{7}{|l|}{ Province } \\
\hline Gansu & 0.34 & 3.56 & 1.67 & 0.08 & 5.66 & 5.5 \\
\hline Inner Mongolia & 3.57 & 1.69 & 4.6 & 4.62 & 14.71 & 3.0 \\
\hline Xinjiang & 2.09 & 6.5 & 4.65 & 1.39 & 14.65 & 3.7 \\
\hline Qinghai & 24.8 & 2.39 & 4.38 & 0.17 & 31.79 & 5.5 \\
\hline \multicolumn{7}{|l|}{ Occupation } \\
\hline Farmer & 1.00 & 3.84 & 2.14 & 0.53 & 7.53 & 4.9 \\
\hline Herdsman & 8.77 & 4.23 & 6.90 & 4.09 & 24.02 & 3.6 \\
\hline $\begin{array}{l}\text { Herdsman and } \\
\text { farmer }\end{array}$ & 2.58 & 5.44 & 2.68 & 1.02 & 11.72 & 4.1 \\
\hline Local TVE worker & 1.33 & 5.87 & 2.56 & 2.10 & 11.85 & 2.8 \\
\hline Outside TVE worker & 0.01 & 2.17 & 0.25 & .. & 2.43 & 2.2 \\
\hline Local manager & 3.33 & 1.64 & 2.61 & .. & 7.58 & 4.6 \\
\hline Retired & 2.57 & 4.01 & 4.01 & .. & 10.60 & 1.0 \\
\hline Other & 2.22 & 2.01 & 2.44 & 1.18 & 7.91 & 1.4 \\
\hline Spending per month & 3.09 & 3.99 & 3.37 & 1.47 & 11.96 & 4.4 \\
\hline All households & $1,367,177$ & $1,359,783$ & $1,367,753$ & $1,369,186$ & $1,357,172$ & $1,357,172$ \\
\hline
\end{tabular}

Households that have renewable energy devices, such as small wind, hybrid, or photovoltaic systems, are still spending more than households without any renewable energy devices. In general, households with renewable energy systems have higher incomes and spend more on all different types of lighting services (Table 3.8). The use of renewable energy for lighting, however, appears to be a significant substitute for petroleum-based fuels. It is interesting that the use of butter for lighting does not decline when households use renewable energy, further reinforcing the notion that it is used for religious and ceremonial purposes. The use of dry cell batteries also does not decline, but rather actually increases in households using renewable energy systems. This challenges 
the notion that renewable energy is a substitute for all batteries used by rural households; dry cell battery usage is determined largely by income, and the batteries are generally used for mobile forms of lighting.

Table 3.8: Monthly Spending on Lighting for Households Using Renewable Energy Systems

\begin{tabular}{|c|c|c|c|c|c|c|c|}
\hline & $\begin{array}{l}\text { Candles } \\
\text { or butter }\end{array}$ & $\begin{array}{c}\text { Kerosene, } \\
\text { diesel, or } \\
\text { gasoline }\end{array}$ & $\begin{array}{l}\text { Dry cell } \\
\text { batteries }\end{array}$ & $\begin{array}{c}\text { Small } \\
\text { generator } \\
\text { set }\end{array}$ & All energy & $\begin{array}{l}\text { As \% of } \\
\text { income }\end{array}$ & $\begin{array}{c}\text { Income } \\
\text { per month }\end{array}$ \\
\hline \multicolumn{8}{|c|}{ PV home systems } \\
\hline Nonusers & 3.05 & 4.02 & 3.36 & 1.48 & 11.96 & 4.5 & 632.59 \\
\hline Users & 6.35 & 0.97 & 4.42 & 0.49 & 12.34 & 1.7 & $1,122.53$ \\
\hline \multicolumn{8}{|c|}{ Small wind systems } \\
\hline Nonusers & 2.91 & 4.38 & 2.93 & 1.00 & 11.26 & 4.7 & 456.11 \\
\hline Users & 4.27 & 1.42 & 6.31 & 4.56 & 16.61 & 2.3 & $1,832.51$ \\
\hline \multicolumn{8}{|c|}{ All users of $P V /$ wind/hybrid/systems } \\
\hline Nonusers & 2.87 & 4.42 & 2.92 & 1.00 & 11.25 & 4.8 & 451.05 \\
\hline Users & 4.41 & 1.40 & 6.13 & 4.29 & 16.29 & 2.3 & $1,770.52$ \\
\hline Total & 3.09 & 3.99 & 3.37 & 1.47 & 11.96 & 4.4 & 637.76 \\
\hline
\end{tabular}

Note: The percentage of households using renewable energy systems is presented in Table 3.6.

Source: China Market Survey 1998.

Finally, another interesting finding from this study is that the households using small wind systems also spend more on small generators. The amount of monthly spending on small generating systems-which includes private or neighbor-owned small generator sets or community-village grids-indicates that a significant number of wind system users also use small generator systems. One reason for this might be that during the summer months, there is not enough wind for electricity everyday, and households without a source of electricity may have to do without lighting and television during these periods. In addition, about 37 percent of small wind system users reported that their systems broke down at least once during the previous 12 month. Perhaps because of such reliability problems, about 14 percent of all households that use small wind systems also get electricity from a generator or small grid electricity system. Another significant finding is that the households that have wind systems have monthly incomes of greater than Y 1,800, while households with photovoltaic systems have incomes of Y 1,100 per month.

\section{Attitudes And Preference toward Energy ServiceS}

The attitude toward lighting services is important for understanding whether households would be inclined to purchase photovoltaic systems. In general, the survey indicated that people in rural areas who do not have access to grid electricity have a very 
favorable attitude toward electric lighting. The results in this chapter are based on attitude questions in which households were asked to agree or disagree with a list of statements.

The households perceive that having electricity is important for both reading and studying. Virtually all households agree that it is easier to read with electric light compared with kerosene lamps, and children are more likely to study in the evening (Table 3.9). Almost all members of households in areas without electricity understand that electricity can provide a higher quality of lighting that makes it possible to read and complete close work in the evenings. The only province in which the favorable rating was less than 90 percent was Qinghai.

Most of the households in these areas without electricity are unhappy with the light they get from their current fuels or energy sources. More than three-quarters of the households in the survey disagree with the statement that they are extremely happy with their current lighting fuel, and this includes a large number of households with renewable energy systems. 
Table 3.9: Household Energy Attitudes and Lighting Preferences (percent of households agreeing with statement)

\begin{tabular}{|c|c|c|c|c|c|c|c|}
\hline & \multicolumn{4}{|c|}{ Provinces } & \multicolumn{3}{|c|}{ All provinces } \\
\hline & Gansu & $\begin{array}{c}\text { Inner } \\
\text { Mongolia }\end{array}$ & Xinjiang & Qinghai & $\begin{array}{c}\text { No } \\
\text { electricity }\end{array}$ & $\begin{array}{c}\text { With } \\
\text { electricity }\end{array}$ & Total \\
\hline \multicolumn{8}{|l|}{ Lighting } \\
\hline $\begin{array}{l}\text { Reading is easier } \\
\text { with electric } \\
\text { light compared } \\
\text { to kerosene. }\end{array}$ & 99 & 99 & 94 & 82 & 96 & 98 & 96 \\
\hline $\begin{array}{l}\text { Because of good } \\
\text { light, children } \\
\text { study more at } \\
\text { night. }\end{array}$ & 99 & 99 & 95 & 78 & 95 & 99 & 96 \\
\hline $\begin{array}{l}\text { PV systems are a } \\
\text { good source of } \\
\text { electricity for } \\
\text { lighting. }\end{array}$ & 70 & 31 & 38 & 42 & 56 & 27 & 51 \\
\hline $\begin{array}{l}\text { My family is } \\
\text { extremely } \\
\text { happy with the } \\
\text { light we get } \\
\text { from our } \\
\text { current fuel. }\end{array}$ & 12 & 19 & 17 & 11 & 14 & 25 & 15 \\
\hline $\begin{array}{l}\text { I complete work } \\
\text { in my house } \\
\text { after it is dark } \\
\text { outside. }\end{array}$ & 81 & 77 & 64 & 72 & 72 & 77 & 74 \\
\hline \multicolumn{8}{|l|}{$\begin{array}{l}\text { Television, News, } \\
\text { and Entertainment }\end{array}$} \\
\hline $\begin{array}{l}\text { Television takes } \\
\text { study time } \\
\text { away from } \\
\text { children. }\end{array}$ & 63 & 64 & 26 & 35 & 48 & 79 & 55 \\
\hline $\begin{array}{l}\text { Watching } \\
\text { television } \\
\text { would provide } \\
\text { my family with } \\
\text { great } \\
\text { entertainment. }\end{array}$ & 98 & 98 & 79 & 63 & 88 & 96 & 90 \\
\hline $\begin{array}{l}\text { It is difficult for } \\
\text { my family to } \\
\text { get news and } \\
\text { information. }\end{array}$ & 85 & 80 & 67 & 50 & 76 & 71 & 75 \\
\hline \multicolumn{8}{|l|}{ Security } \\
\hline $\begin{array}{l}\text { (i) My family } \\
\text { feels secure in } \\
\text { the evening. }\end{array}$ & 88 & 88 & 84 & 65 & 83 & 90 & 86 \\
\hline $\begin{array}{l}\text { (ii) Light at night } \\
\text { is useful to }\end{array}$ & 69 & 71 & 59 & 60 & 64 & 71 & 65 \\
\hline
\end{tabular}




$\begin{aligned} & \text { keep the herd } \\ & \text { together. } \\ & \text { Health } \\ & \text { Lighting with } \\ & \text { kerosene or } \\ & \text { diesel can } \\ & \text { cause health } \\ & \text { problems. }\end{aligned}$
Source: China Market Survey 1998.

Households with access to some form of electricity for lighting, including photovoltaic systems, small wind systems, photovoltaic-wind hybrid systems, small generators, and community-village grids, are happier with their lighting source compared to those without electricity. However, a significant number of these households are still unhappy with their lighting situation. The households with some form of electricity are happier with their lighting source, but the number is still somewhat low, involving only one-quarter of the households with systems. In the provinces of Inner Mongolia and Qinghai, where a great enough number of households have photovoltaic systems, it was found that between 33 and 46 percent of the households with some form of electricity were satisfied with their lighting services (Table 3.10).

Table 3.10: Satisfaction with Lighting Source According to Electricity Source (percent of households agreeing with statement)

\begin{tabular}{lccccc}
\hline & \multicolumn{2}{c}{$\begin{array}{c}\text { Percentage agreeing with statement "my family is happy with } \\
\text { the light we get from our current fuel" }\end{array}$} \\
\hline & Gansu & $\begin{array}{c}\text { Inner } \\
\text { Mongolia }\end{array}$ & Xinjiang & Qinghai & Total \\
\hline $\begin{array}{l}\text { No electricity } \\
\text { Generate their own electricity (all } \\
\quad \text { systems) }\end{array}$ & 14 & 15 & 21 & 6 & 14 \\
$\quad \begin{array}{l}\text { PV system } \\
\text { Wind system }\end{array}$ & n.a. & 34 & 13 & 47 & 34 \\
\hline
\end{tabular}

Note: N.a. means that there are not enough households that own systems to be relevant to question.

Source: China Market Survey 1998.

The low satisfaction level for the households with some form of electricity may be because of several factors. First, close to 40 percent of owners of photovoltaic systems reported that the photovoltaic systems they own are too small and do not provide enough electricity for their family needs. Second, a large number of owners of photovoltaic systems in Qinghai are experiencing problems with their electric lamps (a detailed discussion is provided in Chapter 4). Finally, the wind systems do not provide electricity 
for the entire year, because of insufficient winds. The relatively large number of unsatisfied customers suggests a need for further research into the opportunities of photovoltaic systems for this market segment.

Households, especially those who have access to electricity, are aware of the utilities and benefits of electricity services for education and entertainment. An overwhelming majority of surveyed households-and an even larger proportion of those with some form of electricity-believe that electricity is very useful for their productive activities, such as keeping herds together. Also, most households, and especially those who have access to electricity, reported that they complete their work in the evening after it was dark outside.

Concerning entertainment, 9 out of 10 households agree that watching television would provide their family with great entertainment, but there is a concern among many households, especially those with electricity, that television takes study time away from children.

On the issue of access to news and information, many households in Gansu and Inner Mongolia (85 and 75 percent, respectively) feel that it is difficult for them to get news and information, but fewer households in Qinghai and Xinjiang feel the same. About 50 and 67 percent of households in Qinghai and Xinjiang, respectively, agree that it is difficult for them to get news and information (see Table 3.9). Interestingly, households with access to electricity feel that it is easier for them to get news compared to those without electricity. This finding suggests that having electricity may reduce the feeling of isolation among those who live in very remote areas of the country.

The rural households also recognize that using electricity is a cleaner form of lighting compared to kerosene. Two-thirds of the surveyed households in three provinces feel that lighting with kerosene or diesel can cause health problems. One possible reason for the lower number of households in Qinghai that believe that kerosene causes indoor air pollution is that most households in Qinghai are used to intense smoke in their homes. Typically, herders in Qinghai use dried dung, which emits an intense level of smoke when used for cooking.

In sum, the findings verify that most households would like to have access to the better lighting, entertainment, and information available with access to electricity. They are very knowledgeable about the benefits of electricity. In addition, once households have directly experienced the benefits of electricity, they become dissatisfied with the service limitations of smaller systems.

\section{Knowledge of And Access to Photovoltaic Systems}

Because electricity is so extensive in China, most households are aware of the benefits of electricity. Not all households in the remote sample areas of this study, 
however, have heard about photovoltaic systems. About one-third of the households in the provinces have never heard about photovoltaic systems, and about two-thirds of them have not heard about wind-photovoltaic hybrid systems (see Table 3.11). The households that have heard about systems have either seen a system at their neighbor's or have heard about them from a neighbor.

Table 3.11: Household Knowledge of Renewable Energy Systems (percent of households who have never heard of systems)

\begin{tabular}{lccccc}
\hline System & Gansu & $\begin{array}{c}\text { Inner } \\
\text { Mongolia }\end{array}$ & Xinjiang & Qinghai & Total \\
\hline PV systems of 20 watts & 37 & 32 & 31 & 32 & 34 \\
Small wind-PV hybrid systems & 71 & 56 & 70 & 74 & 67 \\
\hline
\end{tabular}

Source: China Market Survey 1998.

Thus, word of mouth has played a very important role in disseminating information about photovoltaic systems. Opinion leaders appear to be a significant source of information with regards to the spread of such systems. Many people, however, still have not heard about the renewable energy systems. More than one-third of households have never heard about these systems, which illustrates that the retailers still are not reaching a significant proportion of the potential market. There is still scope for programs that raise awareness of these systems, an issue that will be addressed in the concluding chapter of this report.

\section{CONCLUSION}

A fairly large population in the remote areas of China has no access to electricity. Interestingly, many of these households are already using renewable energy sources, such as wind and to limited degree photovoltaic systems. Even the households with photovoltaic and wind energy systems, however, are not totally satisfied with the service they are receiving from them. There is discontent over the quality and quantity of lighting received from such systems. Also, there are still large proportions of these populations that do not have knowledge of the availability of these systems or the wider technical options that are available to them. Finally, there is some degree of dissatisfaction with the existing systems. Many of these issues are addressed in the next chapter, which involves a more detailed analysis of households with photovoltaic energy systems. 


\section{PROFILE OF HOUSEHOLDS WITH PHOTOVOLTAIC SYSTEMS}

In this chapter, a profile is developed for the households that have purchased photovoltaic systems. An understanding of the existing customer base for photovoltaic systems is essential for any program that has the goal of expanding the market for these systems. The characteristics of photovoltaic system owners that are examined include level of income, assets, credit experience, education, type of photovoltaic system owned, methods of purchase, system performance, and quality of services.

The study was designed to survey households with photovoltaic systems, even if they were not selected as part of the random sample (see Appendix B for details). It was fortunate that enough households were selected as part of the random sample in Inner Mongolia and Qinghai so that a special sample did not have to be drawn. In other words, the owners of photovoltaic systems in these two provinces are representative of the region. There were not enough sampled owners of systems in Gansu and Xinjiang Provinces, however, so in the course of conducting the survey, a purposive sample of photovoltaic system owners was selected. Although these households cannot be considered representative for the provinces, they provide valuable insight into the markets for renewable energy in the region of the survey.

\section{Profile of Photovoltaic System Owners}

Most owners of photovoltaic systems in the four provinces are herders. More than 90 percent of photovoltaic system owners in Inner Mongolia are herder households. About 84 and 63 percent of photovoltaic system owners in Qinghai and Xinjiang, respectively, are herders, and many of the remaining households have mixed occupations of farming and herding. Only in Gansu do farmer households own photovoltaic systems, mainly because almost all the households in this province are farmers. Also, in this province the households with photovoltaic systems were not part of the random sample, and systems were probably distributed or subsidized as part of a government program.

Photovoltaic system owners also tend to have higher incomes, greater assets, and more education than those who do not own systems. The income categories used in Table 4.1 are based on the income deciles for the entire population of the study. This gives a view of where households owning photovoltaic systems fall within the income distribution of the provinces. It should be remembered that because of differing income distributions for the provinces, there are more households in the lower half of income distribution for Gansu (75 percent) and a greater number of households in the higher half for the other provinces (65-85 percent). 
The households with photovoltaic systems all have incomes in the highest half of the income distribution for the four provinces (see Figure 4.1). Households with monthly incomes below Y 300 or close to $\$ 40$ cannot readily afford to purchase households systems. Below this level only 10 percent of the households own systems. As mentioned, owners of photovoltaic systems in Gansu are poorer than in the other provinces. The main reason that some of the low-income households in Gansu own photovoltaic systems is that they have received them as part of a poverty reduction program.

Figure 4.1: Distribution of Owners of Photovoltaic Systems Based on Income Deciles

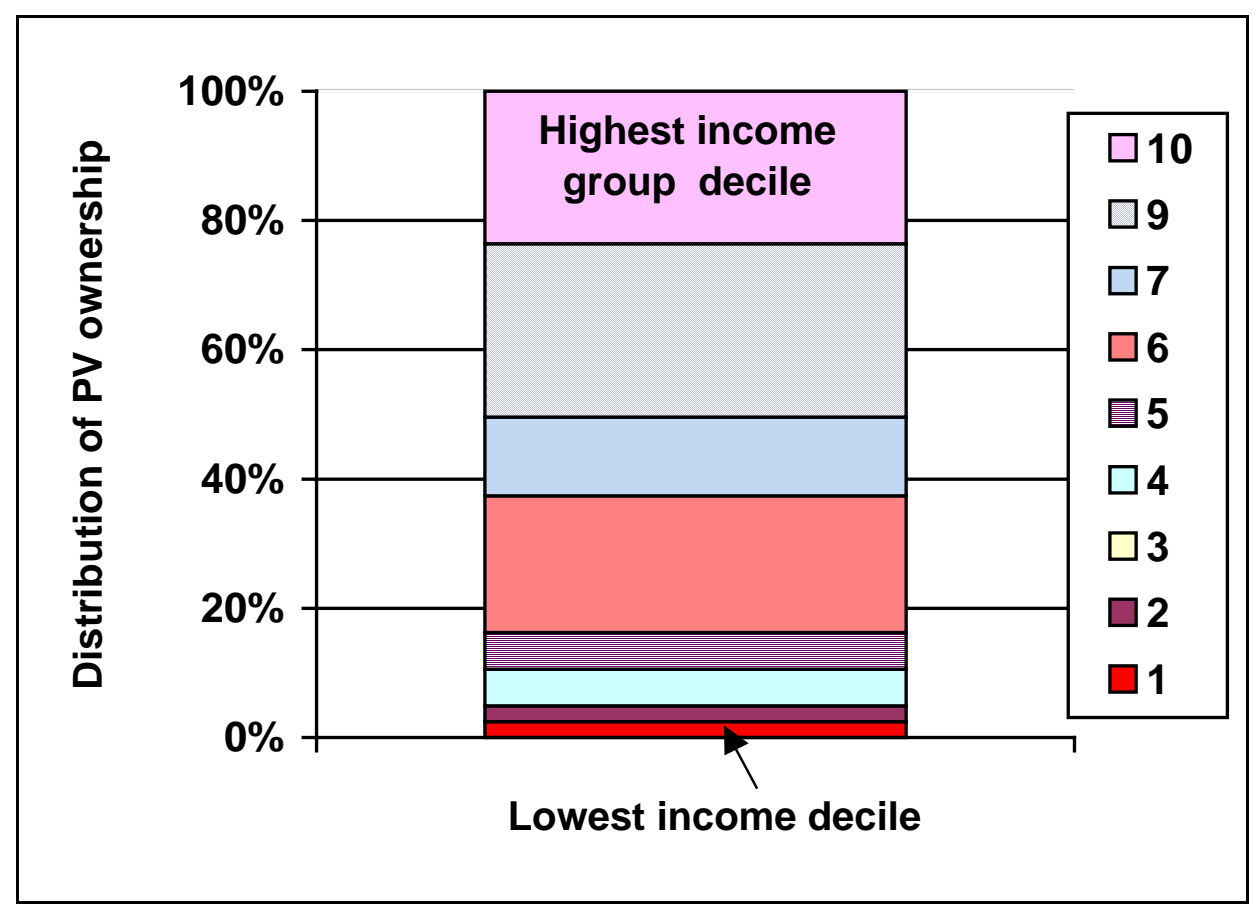

Source: China Market Survey 1998.

Given these results, as expected, the average income of households that own a photovoltaic system is higher than the average incomes for the provinces. The average income for all the 143 photovoltaic system owners is about Y 966 (just over \$100), which is about Y 300 higher than the average income for the general population in this study. ${ }^{9}$

\footnotetext{
${ }^{9}$ The smaller average income could result from that fact that data used to describe solar photovoltaic system owners for the province were not randomly selected, and very few cases showed up in the data.
} 
Thus, the typical owner of a household photovoltaic system has greater income than the general population but the threshold for purchasing such systems is below the average income for the areas in the study. As indicated in Table 4.1, the threshold for households that have purchased the systems with cash is Y 275 per month or close to $\$ 35$, and they are likely to have a significant number of livestock as well.

Table 4.1: Owners of Photovoltaic Systems Whose Household Monthly Income Falls within Each Income Category for All Households (percent)

\begin{tabular}{|c|c|c|c|c|c|}
\hline $\begin{array}{l}\text { Household monthly income deciles for } \\
\text { all provinces }\end{array}$ & Gansu & $\begin{array}{c}\text { Inner } \\
\text { Mongolia }\end{array}$ & Xinjiang & Qinghai & Total \\
\hline$<51.67$ & 13 & .. & .. & 1 & 2 \\
\hline $51.67-103.33$ & .. & .. & .. & 3 & 2 \\
\hline $103.34-155.83$ & .. & .. & .. & .. & .. \\
\hline $155.84-208.33$ & 19 & .. & 6 & 3 & 5 \\
\hline $208.34-275.00$ & 12 & 7 & 6 & 3 & 5 \\
\hline $275.01-378.33$ & 19 & .. & 12 & 22 & 18 \\
\hline $378.34-500.00$ & .. & .. & 19 & 12 & 11 \\
\hline $500.01-716.66$ & .. & 13 & 25 & 15 & 14 \\
\hline $716.67-1275.00$ & .. & 27 & 19 & 27 & 23 \\
\hline$>1275.01$ & 37 & 53 & 13 & 14 & 20 \\
\hline $\begin{array}{l}\text { Income per household per month (PV } \\
\text { households }\end{array}$ & 1,241 & 2,131 & 644 & 791 & 966 \\
\hline $\begin{array}{l}\text { Income per household per month } \\
\text { (general population) }\end{array}$ & 208 & 1,370 & 713 & 597 & 636 \\
\hline Asset value (PV households) & 49,994 & 69,351 & 33,396 & 74,891 & 66,825 \\
\hline Asset value (general population) & 5,311 & 51,910 & 18,505 & 52,802 & 22,406 \\
\hline $\begin{array}{l}\text { Number of sample households with } \\
\text { systems }\end{array}$ & 16 & 15 & 16 & 96 & 143 \\
\hline
\end{tabular}

.. Negligible.

Note: Households in Gansu and Qinghai Provinces were not selected at random for interview, but households in Inner Mongolia and Qinghai were randomly selected for interview.

Source: China Market Survey 1998.

Similar to income, the average value of livestock owned by owners of photovoltaic systems is significantly higher than the provincial average. Based on the combined income and asset profile of owners of photovoltaic systems, owners can be classified into four groups. Households in the first group have income and assets that are within the highest half of the general population. This group accounts for about 82 percent of owners of photovoltaic systems selected for interview (Figure 4.2). The second group is interesting because it involves households with low income, but with high assets. This group accounts for 9 percent of owners of photovoltaic systems, in spite of their low incomes. 
The remaining two groups account for only about 9 percent of total system owners. This confirms that income and the total value of assets owned, particularly livestock, are complementary indicators of whether households can afford to purchase a photovoltaic system. Almost all owners of photovoltaic systems in the third and fourth groups-high-income and low-asset, and low-income and low-asset-are from Gansu Province. As indicated, these households may have acquired their photovoltaic systems through the government-sponsored poverty alleviation program with significant subsidies from the government or other sources.

The households that own photovoltaic systems generally have higher educational levels compared with households without photovoltaic systems. In households that own photovoltaic systems, more than 94 percent of the heads of households in Xinjiang and Gansu Provinces and all the heads of households in Inner Mongolia could read. In Qinghai about two-thirds of households with photovoltaic systems could read. Furthermore, the heads of households with photovoltaic system owners in Gansu and Xinjiang Province generally have higher levels of education compared with the provincial averages. Educational levels of owners of photovoltaic systems in Qinghai are higher than the provincial average. Clearly, there is a strong link between education and ownership of households photovoltaic systems.

\section{Figure 4.2: Distribution of Photovoltaic Owners Based on Income and Assets Owned}

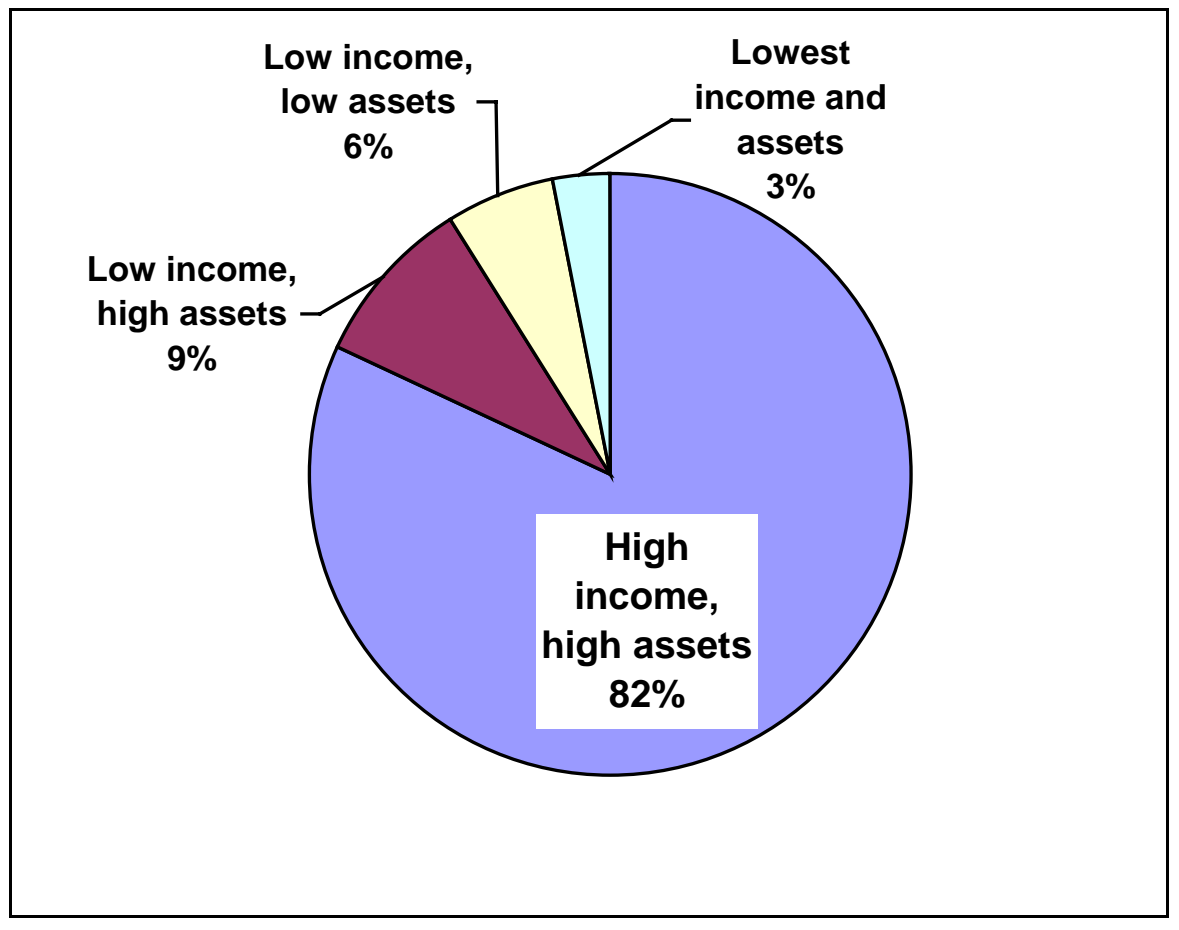

Source: China Market Survey 1998. 
The reasons for households to purchase a photovoltaic system included better lighting and the ability to watch television, among others. As expected, virtually all the owners of photovoltaic systems cited that they bought their systems to obtain better lighting. Television viewing was also a primary reason for more than 80 percent of households' owning systems in Gansu. Some households also indicated that the systems were cheaper to use for lighting compared to kerosene or other fuels. Finally, many families with systems felt that they were important for their children's education.

\section{The Type of Photovoltaic System Purchased By Households}

All households that owned photovoltaic systems had only one system, and these systems were purchased with cash. The households with photovoltaic systems rank in the highest half of the income distribution for the provinces, and most are in the top 30 percent. Generally, households do not perceive that the systems are overly expensive. Although about two-thirds of owners of photovoltaic systems in Xinjiang and Qinghai thought that the systems were expensive, in Inner Mongolia and Gansu most households thought that that the systems were priced fairly.

Although credit is available for other purposes in the provinces, it has not been used for the purchase of household photovoltaic systems. As a consequence, it is not surprising that the households with photovoltaic systems have limited experience with credit, and that few distinctions exist regarding the use of credit between households with and without photovoltaic systems. Among the four provinces, the proportion of owners of photovoltaic systems in Gansu and Qinghai who have taken loans before is almost the same as the general population, but this does not hold for Inner Mongolia and Xinjiang (Table 4.1). Only about a third of owners of photovoltaic systems in Gansu and a tenth in Qinghai have taken a loan before, but the figures are higher for Inner Mongolia and Xinjiang. About half the owners of photovoltaic systems in Inner Mongolia and a third in Xinjiang have taken loans before. Furthermore, there is no difference in the amount, term, and purpose of the loans between owners of photovoltaic systems and other households in the provinces.

The typical size of photovoltaic systems owned by rural households tends to be small, at about 20 watts (see Table 4.2). This finding is consistent with other recent international studies of photovoltaic system sales and ownership patterns. About 76 percent of owners of photovoltaic systems reported that they own 20-watt systems; 14 percent own system of 30-50 watts; and the rest are divided between very small (less than 20 watts) and very large systems (larger than 50 watts). As expected, the larger systems are more expensive, and are purchased by households whose incomes fall in the upper 20 percent of the income distribution (see Figure 4.3). 
Table 4.2: The Nature of Photovoltaic System Purchases in Four Provinces

\begin{tabular}{lccccc}
\hline $\begin{array}{l}\text { Household monthly income deciles } \\
\text { for all provinces }\end{array}$ & Gansu & $\begin{array}{c}\text { Inner } \\
\text { Mongolia }\end{array}$ & Xinjiang & Qinghai & Total \\
\hline $\begin{array}{l}\text { Size of systems (watts for modules) } \\
\text { Average price of systems }\end{array}$ & 19 & 43 & 24 & 22 & 24 \\
$\begin{array}{l}\text { Number of years with system } \\
\text { (\% of households) }\end{array}$ & 1,644 & 1,244 & 1,493 & 1,740 & 1,661 \\
$\quad$ One year & 33 & 13 & 27 & 29 & 28 \\
$\quad$ Two years & 47 &.. & 34 & 40 & 35 \\
$\quad$ Three years & 13 &.. & 33 & 20 & 18 \\
$\quad$ Four years &. &.. &.. & 1.0 & 1 \\
$\quad$ Five years & 6 & 7 &. & 8 & 7 \\
$\quad$ More than five years &. & 80 & 6 & 2 & 11 \\
$\quad$ Total & 100 & 100 & 100 & 100 & 100 \\
$\begin{array}{l}\text { Experience with credit } \\
\text { \% of households) }\end{array}$ & & & & & \\
$\quad$ PV system owners & 36 & 50 & 31 & 8 & 18 \\
$\quad$ General population & 30 & 29 & 43 & 10 & 33 \\
\hline Number of systems surveyed & 16 & 15 & 16 & 96 & 143 \\
\hline .. Negligible. & & & & & \\
Source: China Market Survey 1998. & & & & &
\end{tabular}

Although photovoltaic home systems have been in use in these four provinces for some time, about 80 percent of the owners of photovoltaic systems have purchased their systems during the past three years. This indicates that the market for photovoltaic systems is relatively new. The only exception is in Inner Mongolia where the average photovoltaic system owned by households is larger and less expensive than in the other provinces. The reason for this is that households in Inner Mongolia have been using photovoltaic systems for about a decade. At the time of purchase, the prices were lower than they are today..$^{10}$ Also, the systems that were available at that time were subsidized through a government program. Fewer recent purchases of systems have been reported in Inner Mongolia, however, where wind systems are prevalent. Recently, the subsidies for wind systems were reduced; it is now a commercial program. By contrast, the program for photovoltaic systems has been mainly on a demonstration basis. Recently, the subsidies for photovoltaic systems have been largely phased out. In spite of this, the sales of photovoltaic systems have been increasing, but it is from a very small base.

${ }^{10}$ A significant number of photovoltaic system owners in Inner Mongolia have had their systems for a long time, and the reported prices paid by the households were relatively low, reflecting the subsidized prices at the time. 


\section{Figure 4.3: Average Size of Photovoltaic System Owned by Income}

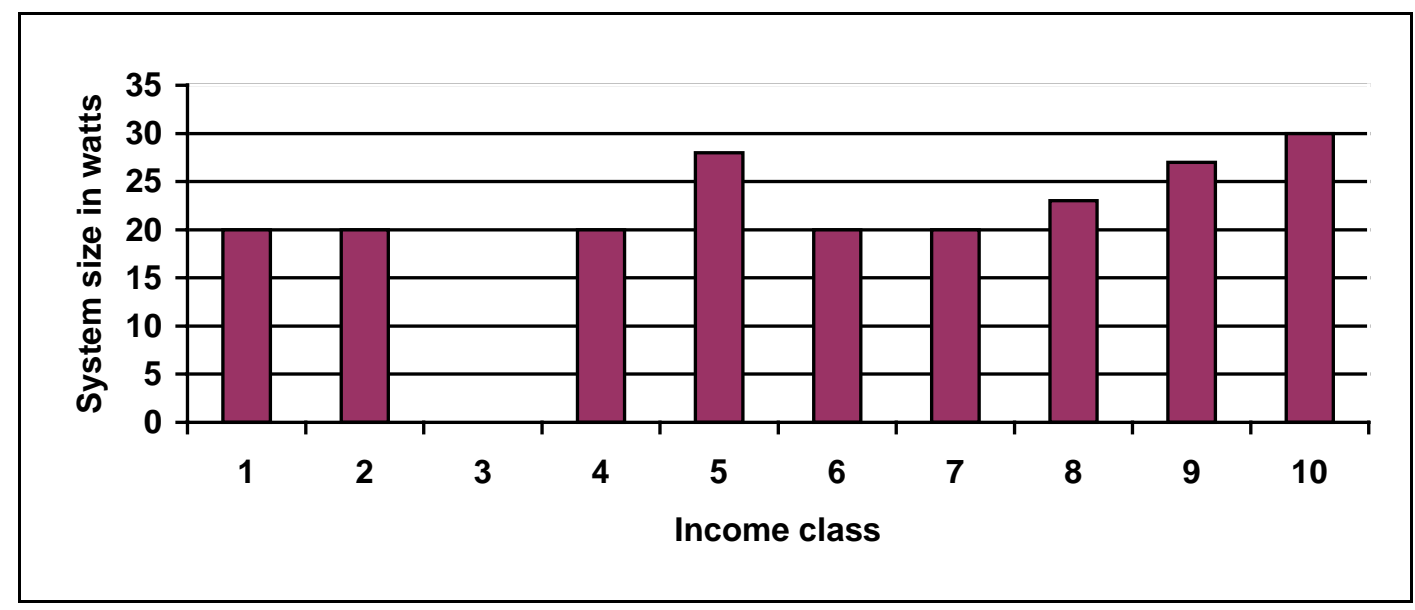

Note: There were no systems owned in income class 3.

Source: China Market Survey 1998.

Typically, households purchase photovoltaic systems for better lighting and for watching television. The people benefit from these uses by being able to read and write, work, watch news and entertainment programs on television, and enjoy social visits in the evening. On average, households use electricity from photovoltaic systems for lighting for about two hours per evening in Inner Mongolia and for up to five hours in Xinjiang. With respect to the adequacy of photovoltaic systems, about 40 percent of system owners in Gansu and Inner Mongolia reported that the electricity from their systems is just enough for household use, compared to about 50 percent and 67 percent of households in Qinghai and Xinjiang, respectively. In general, close to 40 percent of the owners of photovoltaic systems reported that electricity generated from their photovoltaic system is not enough for household use. This finding appears to confirm that households in these four provinces settled on smaller systems because of the cost, so there may be a market for upgrading systems through the addition of system components in the future.

\section{System Performance AND Quality Of SERVICE}

Most of the photovoltaic systems in the provinces have performed relatively well so far. As indicated in the previous chapter, however, more than 60 percent of owners of photovoltaic systems have had their systems for less than two years. Most of the systems and system components are designed to last three years or longer. For instance, photovoltaic panels are designed to last 20 years, the system controllers can last 10 years, and the batteries generally can continue working about 3 years. Because of this, more than 
60 percent of system owners in Gansu, Inner Mongolia, and Xinjiang reported that their systems have never broken down.

Among those in Gansu, Inner Mongolia, and Xinjiang who reported to have system problems, the majority indicated that their systems have had problems only once or twice since they bought them. The main problem with the systems has been with the compact fluorescent lamps and the batteries (see Table 4.3). In Qinghai, the lamp failures have been much higher than in the other provinces. The high rate of problems with compact fluorescent lamps, fluorescent tubes, and even the batteries in Qinghai may suggest that the quality of these parts may be below standard, or they may have been installed in poorly designed systems. For instance, many systems are sold without battery controllers. Also, compact fluorescent lamps and fluorescent tubes should last more than two years, given that these light bulbs or tubes are used only a few hours a day. Furthermore, the average ownership of the systems is only 22 months, and during this time the compact fluorescent lamps or fluorescent tube should not have to be replaced. ${ }^{11}$ The reason for the short period of ownership is that most systems have been purchased during the last five years.

For photovoltaic systems in need of repair, the average number of days that the systems were out of service during the last year ranged from 21 to 64 days (see Table 4.3). The reasons for the delays in repairs were mainly because of the difficulty getting parts and the relatively long distances to repair facilities. With the exception of Gansu, the majority of owners of photovoltaic systems take their systems to a repair shop when they have problems with them. Because there are no repair shops in the township or county, photovoltaic system owners have difficulty getting their systems repaired. For instance, owners of photovoltaic systems in Qinghai and Xinjiang often take combined modes of transportation, including bus, truck, horse, or yak. The average distance owners of photovoltaic systems have to travel to reach a repair shop ranges from 118 kilometers in Xinjiang to 455 kilometers in Qinghai. By contrast, owners of photovoltaic systems in Gansu and Inner Mongolia can have their systems repaired closer to their villages. Thus, the after-sales service is very poor, and repair shops tend to be located in larger cities. This raises the question as to whether the shortage of these parts and the long waits for system repairs is adversely effecting the expansion of the markets in these provinces.

\footnotetext{
${ }^{11}$ For example, a 7-watt or 11-watt-12-volt DC compact fluorescent lamps, Solsum brand name made in China and available in the U.S. market, has a life expectancy of approximately 6,000 hours, which means the lamps should last 3 to 6 years depending on usage.
} 
Table 4.3: Experiences with Repairs and Services

\begin{tabular}{|c|c|c|c|c|c|}
\hline & Gansu & $\begin{array}{c}\text { Inner } \\
\text { Mongolia }\end{array}$ & Xinjiang & Qinghai & Total \\
\hline \multicolumn{6}{|l|}{$\begin{array}{l}\text { Number of times PV system has broken } \\
\text { down since it was purchased (\% of } \\
\text { households) }\end{array}$} \\
\hline None & 63 & 77 & 67 & 49 & 55 \\
\hline One time & 13 & 15 & 27 & 5 & 9 \\
\hline Two times & 6 & .. & .. & 9 & 8 \\
\hline Three times or more & 18 & 7 & 6 & 36 & 28 \\
\hline $\begin{array}{l}\text { Average number of days PV system } \\
\text { was out of service (days) }\end{array}$ & 38 & 64 & 28 & 21 & 27 \\
\hline $\begin{array}{l}\text { Average distance to repair shop } \\
\text { (kilometers) }\end{array}$ & 50 & 41 & 118 & 455 & 353 \\
\hline \multicolumn{6}{|l|}{$\begin{array}{l}\text { Part of PV system that was out of } \\
\text { order (\% of households) }\end{array}$} \\
\hline Battery & 33 & 67 & 43 & 33 & 35 \\
\hline Light bulb or tube & 42 & 33 & 67 & 96 & 81 \\
\hline Charge or discharge controller & 36 & .. & .. & 12 & 15 \\
\hline AC/DC adapter &.. & 33 & 20 & .. & 3 \\
\hline $\begin{array}{l}\text { Average total cost of repair (yuan per } \\
\text { repair) }\end{array}$ & 26 & n.a. & 173 & 26 & 41 \\
\hline \multicolumn{6}{|l|}{$\begin{array}{l}\text { Mode of transportation to repair shop } \\
\text { (\% of households) }\end{array}$} \\
\hline Car, bus, truck, or motorcycle & 100 & 100 & 50 & 53 & 59 \\
\hline Horse, yak, or cart & .. &.. & 33 & 3 & 7 \\
\hline Combination of above & .. & .. & 17 & 44 & 34 \\
\hline Number of systems surveyed & 16 & 15 & 16 & 96 & 143 \\
\hline
\end{tabular}

\section{CONCLUSION}

At present, the main market for photovoltaic systems in the four provinces is the households in the highest half of the income distribution. Such households also have fairly high levels of education. Most households buy systems that are affordable to them, but perhaps which do not give the level of electricity service that they desire. Most systems in the region are less than two years of age and are relatively small-about 20watt systems.

Currently, the market is for cash sales only, and credit is not used for the purchase of systems. Although the majority of systems seem to be performing well, the main problems are with the lamps and batteries. When systems do need repairs, few convenient 
facilities are available, and the average wait time for repairs is about one month. In spite of the problems, almost all photovoltaic system owners across all four provinces are satisfied with the performance of their systems and would recommend them to relatives or friends.

The general characteristics of the households in remote areas without access to grid electricity were described in a previous chapter. This chapter has provided a profile of typical owners of photovoltaic systems, with systems and without systems have been detailed. In the next chapter, insights from both of these groups-the adapters of photovoltaic systems and the general population-are used to develop a profile of the potential market for systems in the four provinces. 


\section{POTENTIAL MARKET FOR PHOTOVOLTAIC SYSTEMS IN FOUR PROVINCES}

This chapter provides an analysis of the affordability of photovoltaic systems, and includes an estimate of the size of market based on different ways for people to pay for the systems. The analysis is based on a comparison of the characteristics of rural households in villages without grid electricity services and a profile of current photovoltaic system owners. In two provinces, the random sample contained a significant number of households with renewable energy systems. Because these households are representative of the households without access to grid electricity in these two provinces, the estimate the size of the potential market in these areas is more precise.

The main criteria that have been used to determine the potential market for renewable energy systems are income, assets, education, and the attitude toward credit of the owners of photovoltaic systems and the surveyed rural households. In the case of China, the existing expenditures on energy are very low, so this is not a useful indicator for estimating the market for renewable energy systems. In addition, the households with renewable energy systems seem to continue to spend close to the same amount of money on lighting services provided by kerosene, diesel, candles and other sources of energy. As a consequence, the purchase of a renewable system does not appear to be a replacement for current fuels, but rather it involves additional or new uses of the services made possible by the availability of electricity.

\section{Ability to Pay Cash for Photovoltaic Systems}

In the previous chapter, it was found that households with high incomes and with fairly great assets could afford to purchase photovoltaic systems. In terms of income, about 90 percent of all owners of photovoltaic systems in Inner Mongolia, Qinghai, and Xinjiang are concentrated in the upper 50 percent of the income distribution for the provinces. The main exception is Gansu, a very poor province where photovoltaic systems have been distributed through a government subsidy program. Assets may also be an important factor in making photovoltaic systems affordable. Virtually all households in Inner Mongolia and Xinjiang, and more than 98 percent of households in Qinghai possess the asset value classified in the upper 50 percent of asset distribution for the provinces. The main exception to this pattern is Gansu, which is a very poor province with both low income and low assets.

Combining the results of the survey of photovoltaic system owners with the general survey, about 41 percent of rural households in the four provinces appear to have similar levels of income and assets as those who have already purchased photovoltaic 
system with cash. The typical system purchased was small-20 watts or less-so these findings apply mainly to small systems. Assuming that a functioning retail market exists in these remote provinces, such households definitely could afford to purchase photovoltaic systems. These households have higher incomes, as well as greater assets, with monthly incomes that are greater than Y 275, and the total value of assets starts at about Y 7,163 per household. In this group are about 562,573 households in the 4 provinces. This includes 171,154 households in Inner Mongolia, 237,329 households in Xinjiang, and 62,425 in Qinghai (see Table 5.1). For Inner Mongolia, it should be cautioned that about half the households have small wind systems, which provides a service similar to that of a photovoltaic system. Thus, the marketing of photovoltaic systems may have to compete with, or in the case of a market for hybrid systems, complement wind systems. Because there is not as much wind during the summer months when solar radiation is the greatest, photovoltaic systems may be the perfect complement to wind systems.

Table 5.1: Households That Could Afford Small Photovoltaic Systems

\begin{tabular}{|c|c|c|c|c|c|}
\hline & Gansu & $\begin{array}{c}\text { Inner } \\
\text { Mongolia }\end{array}$ & Xinjiang & Qinghai & Total \\
\hline \multicolumn{6}{|l|}{ Small systems are affordable } \\
\hline $\begin{array}{l}\text { High-income and high-asset } \\
\text { households }\end{array}$ & 43,838 & 180,186 & 196,991 & 62,026 & 483,040 \\
\hline Percentage of households & 8 & 61 & 47 & 73 & 35 \\
\hline \multicolumn{6}{|l|}{ Small systems may be affordable } \\
\hline $\begin{array}{l}\text { Low-income and high-asset } \\
\text { households }\end{array}$ & 93,775 & 56,064 & 35,596 & 13,471 & 198,906 \\
\hline Percentage of households & 16 & 19 & 9 & 16 & 15 \\
\hline $\begin{array}{l}\text { High-income and low-asset } \\
\text { households }\end{array}$ & 98,988 & 3,962 & 91,708 & 4,473 & 199,131 \\
\hline Percentage of households & 17 & 1 & 22 & 5 & 15 \\
\hline \multicolumn{6}{|l|}{$\begin{array}{l}\text { Small systems are probably not } \\
\text { affordable }\end{array}$} \\
\hline $\begin{array}{l}\text { Low-income and low-asset } \\
\text { households }\end{array}$ & 332,849 & 56,144 & 90,291 & 4,691 & 383,975 \\
\hline Percentage of households & 59 & 19 & 22 & 6 & 35 \\
\hline All households & 569,449 & 296,356 & 414,586 & 84,662 & $1,365,053$ \\
\hline
\end{tabular}

Note: High refers to upper 50 percent brackets and low refers to lower 50 percent brackets.

Source: China Market Survey 1998.

The households in the poorest group are located mostly in Gansu Province. In Gansu about two-thirds of the households have both low income and few assets. As might be expected, the number of households that can afford to purchase systems on a cash 
basis in Gansu is 8 percent of the total population, which is very small compared with the other provinces. The people in the areas without electricity in this province are very poor, and they have little ability to pay for the systems.

These estimates are for all households in the region, whether or not they presently own an alternative energy source, such as a generator set or a wind system. The reason for not excluding the households that already have some other way to generate electricity is that the survey indicated that it is quite common to have multiple means of electricity generation, especially in the higher-income groups. It could even be speculated that the adoption of some form of electrical lighting, along with the new awareness of the benefits of electricity that is associated with the lighting, actually increases the demand for alternative sources of electricity. Therefore, it is assumed in Table 5.1 that demand for photovoltaic systems exists even in households with some other form of electrical lighting. The reason for this is that the households with renewable energy systems have expressed dissatisfaction with the level of service.

\section{Potential Demand For LARger Systems}

More than 50 percent of households reported that they were not satisfied with their level of lighting service. Many households also supplement the service from their renewable energy systems by purchasing energy devices, such as kerosene, candles, and even generator sets. Many households in the upper three income deciles own the larger photovoltaic systems, at a cost of between Y 3,800 and Y 6,000 each. From this, one can infer that the target group for the larger systems is in the top two income deciles. As a result, it is estimated that approximately 264,515 households in all four provinces could afford to buy larger photovoltaic systems with cash. This accounts for 47 percent of the estimated total number of households that could afford to buy a small 20 -watt photovoltaic system with cash (see Table 4.2). As a result, it is quite possible that a demand for larger systems or system upgrades will emerge. It is also conceivable that the larger photovoltaic systems will be in greater demand in the foreseeable future (see Table $5.2)$. 
Table 5.2: Households That Could Afford to Purchase Large Photovoltaic Systems

\begin{tabular}{|c|c|c|c|c|c|}
\hline $\begin{array}{l}\text { Estimated number of households } \\
\text { that: }\end{array}$ & Gansu & $\begin{array}{c}\text { Inner } \\
\text { Mongolia }\end{array}$ & Xinjiang & Qinghai & Total \\
\hline $\begin{array}{l}\text { Could afford a larger system } \\
\text { with cash }\end{array}$ & 3,613 & 133,348 & 84,421 & 23,226 & 244,607 \\
\hline $\begin{array}{l}\text { May be able to afford a larger } \\
\text { system with cash and credit }\end{array}$ & 8,125 & 17,377 & 50,882 & 3,259 & 79,643 \\
\hline $\begin{array}{l}\text { Probably could not afford to buy } \\
\text { a larger system }\end{array}$ & 32,100 & 29,461 & 61,688 & 35,541 & 158,790 \\
\hline $\begin{array}{l}\text { Total number of households in } \\
\text { the upper } 5 \text { income and asset } \\
\text { brackets }\end{array}$ & 43,838 & 180,186 & 196,991 & 62,026 & 483,040 \\
\hline
\end{tabular}

The availability of credit may make it possible for the households below the highest income groups to be able to afford larger systems. Many of these households have access to credit and have used different types of credit. Assuming that the credit could be made available to this middle group of households, close to 80,000 additional households might be able to purchase systems. It should be cautioned, however, that the use of credit for major household purchases is not common in these provinces.

\section{Attitudes and Preferences for Types of System And Payment Methods}

The analysis of affordability showed that about half the households in all four surveyed provinces can afford to buy at least a small 20-watt photovoltaic system with cash. Only 20 percent of all surveyed households across four provinces, however, indicate that they are interested in buying a 20-watt photovoltaic system with cash (Table 5.3). For Inner Mongolia, which has the high penetration of small wind systems, the figure is even lower-at about 11 percent. The situation does not improve much with the possibility of purchasing a system on credit for one or two years. 
Table 5.3: Households Interested in Buying a Different Size Photovoltaic System Using Cash or Credit (percent)

\begin{tabular}{lccccc}
\hline & Gansu & $\begin{array}{c}\text { Inner } \\
\text { Mongolia }\end{array}$ & Xinjiang & Qinghai & Total \\
\hline $\begin{array}{l}\text { Households interested in buying 20- } \\
\text { watt PV systems with: }\end{array}$ & & & & & \\
$\quad$ Cash & 26 & 11 & 13 & 18 & 19 \\
$\quad$ One year credit & 4 & 2 & 5 & 4 & 4 \\
$\quad$ Two years' credit & 1 & 0.5 & 4 & 11 & 2 \\
$\quad$ Households interested in buying 50- & & & & & \\
watt PV systems with: & 25 & 19 & 31 & 19 & 24 \\
$\quad$ Cash & 3 & 4 & 8 & 6 & 4 \\
$\quad$ One year credit & 3 & 0.6 & 19 & 17 & 6 \\
$\quad$ Two years' credit & & & & & \\
Households interested in buying 70- & 18 & 33 & 33 & 32 & 24 \\
watt PV systems with: & 15 & 7 & 16 &.. & 13 \\
$\quad$ Cash & 2 & 1 & 22 & 2 & 5 \\
$\quad$ One year credit & & &
\end{tabular}

.. Negligible.

Note: The survey results presented in this table are based on a series of hypothetical questions designed to gauge the interest and knowledge of respondents about 20-, 50-, and 70-watt PV systems. See Appendix Tables A-6 through A-11 for details. Source: China Market Survey 1998.

Although many households expressed interest in purchasing systems, some families lacked interest. It should be cautioned that the indication of interest among respondents is measured by several hypothetical questions concerning interest in buying photovoltaic systems of three sizes (20,50, and 70 watts). There are several reasons that households might not be interested in purchasing systems. First, many households know nothing about photovoltaic systems. Second, some households are not comfortable with the idea of buying major appliances with credit. Of those who have been exposed to credit, the majority borrowed money for business purposes. Furthermore, their exposure to credit is still very limited. Third, some households are simply not interested in photovoltaic home systems. Fourth, the majority - about 55 percent-indicated that their main reason for not buying the systems was that they believe that photovoltaic home systems are very expensive.

Other reasons were given by households for not being interested in purchasing. They feel that there is "no convenient location to buy them," "they can't get credit," "they worry about the quality," "the system capacity is not enough," or "they will get connected to the grid soon or will purchase a small diesel generator set soon."

Given the hypothetical nature of the questions that were asked of respondents, the results cannot be considered a definitive indication of the market for photovoltaic 
systems. For instance, significant numbers of respondents who are interested in buying systems, particularly the larger sizes, do not have enough income to afford them. On the other hand, a significant number of respondents who are interested in buying systems with a capacity of less than 20 watts have enough income and assets to purchase such systems either with cash or credit. In any event, the results clearly indicate some of the major hurdles to expanding the market for these products.

\section{CONCLUSiON}

This chapter outlined the potential market for photovoltaic systems in remote provinces of China. Many households in these remote areas can afford photovoltaic systems, and in fact, many have already purchased them. The main reason households in these provinces can afford them is that many of them are herders who own many animals. With a significant and growing demand for meat in China, they are able to sell their animals at very attractive prices and earn a high income. In addition to high income, households with higher education levels are more likely to purchase systems than those with lower levels of education.

Affordability does not always translate into the purchase of systems, however. As indicated in this study, in spite of the continuing development of retail markets in these provinces, many problems remain. When systems have problems, households have great difficulties in getting spare parts or repairs. The credit system in the provinces is geared toward seasonal credit for agriculture and not toward the purchase of items for household use. At present, people in the region seem resistant to using credit for large purchases of household appliances. Given the remote locations of these areas and the lack of access to grid electricity, development of any type of market will be challenging. There are reasons for optimism as well, though. Incomes turned out to be higher than expected at the beginning of the study. In one province, about half the households without electricity already have purchased inexpensive wind systems, and close to one-tenth of households in Qinghai have purchased photovoltaic systems for lighting. In the next chapter, policy recommendations based on this study are discussed. 


\section{CONCLUSIONS AND RECOMMENDATIONS}

In many countries, households without access to electricity spend a significant amount of their income on petroleum fuels and batteries for household lighting. In the survey areas covered in this study, people without electricity spend very little of their monthly income on energy, although many households have purchased wind energy systems or electricity generator sets with cash to get improved lighting and communication services. About half the households in the areas surveyed in Inner Mongolia have wind generation systems, and 11 percent of the households have generator sets that run on petroleum fuels. From the survey, it is clear that people value electricity for lighting, communications, entertainment, and other services.

The provinces covered by the study include Gansu, Inner Mongolia, Qinghai, and Xinjian. The areas within these provinces covered by the survey are limited to the counties with more than 15 percent of households that do not have electricity service from a grid system. Further, only communities without access to grid electricity were included in the survey. Within this study area, there are wide variations in occupations, incomes, and levels education. In general, herders are much wealthier than farmers in the provinces. With herders concentrated in Inner Mongolia and Qinghai, as expected, Inner Mongolia has the highest income for the study areas involving only villages without electricity. Many people in the provinces have extensive experience with credit, but the credit is used mostly for productive activities and not for household consumer goods.

\section{The Market for Photovoltaic Systems Exists ANd Is Growing}

The market for photovoltaic systems in the provinces is small, but growing. In two out of the four states, a significant number of households that own photovoltaic systems even show up in our random sample. The existing sales figures for the photovoltaic industry are considerably higher than the numbers indicated by the survey, which is consistent with the companies' reports that they are selling to other areas, especially western Sichuan and Tibet. The systems that people have purchased are mostly small and inexpensive, and have been purchased on a cash basis. People in the households with systems definitely would recommend them to their friends. They value highly the benefits of having electricity, including lighting, entertainment, and information, but the inexpensive systems also can result in maintenance difficulties, such as problems with lights and batteries. People also are not totally satisfied with the level of service they get from such small systems. They want more service from their systems.

In these remote provinces in China, many households are now able to afford to pay for small photovoltaic systems with cash. The study found that about 500,000 
households can afford to pay cash for systems that are less than 20-watt photovoltaic. Most of these households are in Inner Mongolia, Qinghai, and Xinjiang. This estimate includes many households that already own some form of electricity generation, such as a wind generator or a generator set. For instance, in Inner Mongolia about half the households in the study area already have wind systems. We have not excluded these households from the estimated market, because a significant number of households own multiple systems to generate electricity. ${ }^{12}$

In Gansu, the household incomes are generally below the threshold level for the purchase of a system. In this province, a viable commercial market for systems sold on a cash basis appears unlikely. In Gansu, some form of subsidy or credit, or combination of the two, would be necessary to encourage broad adoption of photovoltaic systems.

As might be expected, the households that are purchasing photovoltaic systems generally are literate, and it appears that both education and income are key factors in predicting whether a household will purchase a system. Most of the existing systems are in households that are in the upper half of the income distribution for the areas without electricity, and most of them have higher education levels than average for the population.

Most people in the provinces are not happy with their source of lighting. This includes households with and without renewable energy systems. Households with photovoltaic systems are happy with their performance and would recommend their purchase to a neighbor, but many feel that the systems do not provide enough lighting or other electricity services. Therefore, a significant market may exist to upgrade the existing typical 20-watt systems that people are using today.

One note of caution concerning these results is warranted. The dissatisfaction with the service of renewable systems may be the result of comparisons with grid service levels. Given the extensive reach of the grid service in rural areas of China, unrealistic anticipation or expectations of grid service coming soon to an area would likely be very detrimental to the expansion of the market for renewable systems.

\section{Households ApPear to Have LitTle Interest in USing Credit to Purchase Photovoltaic Systems}

Many households in the survey are utilizing credit for their commercial activities, including farming. They borrow money from rural banks and cooperatives to purchase agricultural inputs and other items. Loans are often of very short duration, with the most

\footnotetext{
12 Although we have not attempted to estimate markets outside the four provinces covered by the survey, an additional 500,000 households without electricity in Tibet and Sichuan are part of the potential market for photovoltaic systems.
} 
common loan being repaid in one year. Presently, credit appears not to be used to purchase consumer durable goods in these areas. In addition, households in the region appeared uninterested in purchasing a photovoltaic system on credit, preferring instead to pay with cash. For wealthy herders, paying with cash would not be much of a problem, because they would only have to sell off a few animals.

To deepen the market by reaching the middle- and lower-income groups, and perhaps to allow higher-income households to purchase larger systems, some form of credit or installment payment is necessary. The lack of interest shown by households toward purchasing consumer durable goods with credit, along with the importance of credit toward deepening the potential market for systems, indicates a need for further work in this area. Therefore, it is recommended that this topic be investigated through focus group interviews that seek the reasons for the lack of interest and explore all potential approaches to increasing the affordability of the systems.

\section{SALES AND AfTer-SAles NeTWORKS NEED TO BE EXPANDED}

Most households in the areas without access to electricity in the remote provinces have no access to retailers that sell photovoltaic systems. Even where systems are sold, there is very little after-sales support for systems. Customers often wait about one month for systems repairs. The average distance to a repair shop varies from 50 kilometers to more than 400 kilometers. Simple parts for common problems with systems, such as lamp failures, are not available locally.

\section{Standards AND SPECIFICATIONS MAY BE IMPORTANT FOR MARKET DEVELOPMENT}

The systems that are being sold in the study area are mainly small systems of less than 20 watts. The practice of selling inexpensive systems makes systems affordable to a wider segment of the population. Less expensive systems are affordable, but there is a higher incidence of repairs and system component failures in areas with many small systems. This can be very costly in terms of product acceptance. If the systems have operational problems in some households-especially those of the early adopters - others may postpone or not purchase systems.

The adoption of mandatory standards and certification of products is one important way to reduce the quality and after-sales service problems found through the survey. Such standards and certification procedures have already been introduced in preparation for the China Renewable Energy Development Project.

\section{CONCLUSION}

With the exception of Gansu, all the other provinces in the study area have significant potential markets for photovoltaic systems, even on a cash basis. At present, the development of these markets in its infancy. Commercial retailers have begun to 
service the three provinces only during the last three years, and they are often in competition with more established firms that have been involved in previous government programs.

There will be many problems that are faced in expanding the market beyond the richest households in the provinces. They include the lack of interest in credit for photovoltaic system purchases by households, the weak existing sales and after-sales networks in the region, and the need to replace system components as the systems begin to age. Also, the high number of wind systems in Inner Mongolia may affect sales in that province.

In spite of the problems, there are significant opportunities. In three of the provinces, a significant number of households can afford to purchase small systems on a cash basis. This number could be expanded greatly if issues are resolved concerning the availability of credit and resistance to using credit. There appears to be a market for system expansion, after the initial purchase of small, affordable systems. The only exception is Gansu where households do not have the requisite income to purchase systems without some type of assistance from the government. Clearly, a different strategy would be necessary for the promotion of household photovoltaic systems in this province. Markets for photovoltaic products in the other provinces are likely to expand quickly, however, as households in the areas seem to appreciate the benefits of electricity from the systems, and many have the necessary income to pay for systems. 


\section{APPENDIX A: DESCRIPTIVE STATISTICS FROM THE NORTHWEST CHINA RURAL ENERGY SURVEY}


Table A-1: Socioeconomic Indicators

\begin{tabular}{|c|c|c|c|c|c|}
\hline & Gansu & $\begin{array}{c}\text { Inner } \\
\text { Mongolia } \\
\end{array}$ & Xinjiang & Qinghai & $\begin{array}{c}\text { All four } \\
\text { provinces }\end{array}$ \\
\hline \multicolumn{6}{|l|}{ Age of head of household } \\
\hline Mean & 40 & 42 & 43 & 45 & 43 \\
\hline Valid N & 715 & 723 & 721 & 719 & 2,878 \\
\hline \multicolumn{6}{|l|}{ Number of persons in the household } \\
\hline Mean & 5 & 4 & 6 & 5 & 5 \\
\hline Valid N & 704 & 724 & 717 & 720 & 2865 \\
\hline \multicolumn{6}{|l|}{ Total monthly income } \\
\hline Mean & 195 & 1580 & 737 & 624 & 785 \\
\hline Valid N & 720 & 724 & 722 & 720 & 2,886 \\
\hline \multicolumn{6}{|l|}{ Total value of livestock owned } \\
\hline Mean & 3,558 & 57,576 & 20,699 & 55,445 & 34,371 \\
\hline Valid N & 718 & 724 & 719 & 719 & 2,880 \\
\hline \multicolumn{6}{|l|}{$\begin{array}{l}\text { Education of head of household } \\
\text { (percent) }\end{array}$} \\
\hline Illiterate & 17 & 6 & 10 & 51 & 21 \\
\hline Primary school & 36 & 44 & 47 & 40 & 42 \\
\hline Junior high school & 35 & 41 & 33 & 9 & 29 \\
\hline Senior high school & 11 & 8 & 8 & 0 & 7 \\
\hline High vocational school & 1 & 1 & 1 & 0 & 1 \\
\hline College and university education & 1 & 0 & 1 & .. & 1 \\
\hline Postgraduate education & .. & .. & .. & .. & .. \\
\hline Valid N & 719 & 722 & 722 & 720 & 2,883 \\
\hline \multicolumn{6}{|l|}{$\begin{array}{l}\text { Highest education of household } \\
\text { member (percent) }\end{array}$} \\
\hline Illiterate & 6 & 1 & 1 & 26 & 9 \\
\hline Primary school & 17 & 14 & 17 & 38 & 22 \\
\hline Junior high school & 42 & 46 & 40 & 24 & 38 \\
\hline Senior high school & 28 & 27 & 24 & 9 & 22 \\
\hline High vocational school & 4 & 6 & 10 & 1 & 5 \\
\hline College and university education & 3 & 5 & 7 & 2 & 4 \\
\hline Post graduate education & .. & .. & .. & .. & .. \\
\hline Valid N & 706 & 700 & 715 & 712 & 2,833 \\
\hline \multicolumn{6}{|l|}{$\begin{array}{l}\text { Occupation of head of household } \\
\text { (percent) }\end{array}$} \\
\hline Farmer & 90 & 34 & 57 & 8 & 47 \\
\hline Herdsman & .. & 62 & 30 & 77 & 42 \\
\hline Mixed herding and farming & 5 & 3 & 9 & 15 & 8 \\
\hline Local TVE worker & 1 & .. & 1 & .. & 0.3 \\
\hline Outside TVE worker & 2 & .. & .. & .. & 0.4 \\
\hline Local manager & 0.4 & 0.3 & 0.4 & .. & 0.3 \\
\hline Retired & 0.1 & 0.3 & 0.4 & .. & 0.2 \\
\hline Other & 2 & 1 & 2 & 0.4 & 1 \\
\hline Valid N & 720 & 722 & 721 & 720 & 2,883 \\
\hline
\end{tabular}

.. Negligible.

Note: TVE stands for township and village enterprise.

Source: China Market Survey 1998. 
Table A-2: Households' Experience with Credit

\begin{tabular}{|c|c|c|c|c|c|}
\hline & Gansu & $\begin{array}{c}\text { Inner } \\
\text { Mongolia }\end{array}$ & Xinjiang & Qinghai & $\begin{array}{l}\text { All four } \\
\text { provinces }\end{array}$ \\
\hline \multicolumn{6}{|l|}{ Credit experience (\% of households) } \\
\hline No $(\%)$ & 68 & 76 & 59 & 89 & 73 \\
\hline Yes $(\%)$ & 32 & 24 & 41 & 11 & 28 \\
\hline Total (valid N) & 637 & 641 & 682 & 596 & 2,556 \\
\hline Average loan amount (yuan) & 1,173 & 3,242 & 4,802 & 2,449 & 3,201 \\
\hline Valid N & 200 & 147 & 279 & 63 & 689 \\
\hline Average length of loan (months) & 16 & 12 & 11 & 26 & 14 \\
\hline Valid N & 202 & 146 & 270 & 64 & 682 \\
\hline \multicolumn{6}{|l|}{$\begin{array}{l}\text { Year of last loan taken (\% of households } \\
\text { with loan) }\end{array}$} \\
\hline $1998(\%)$ & 37 & 25 & 60 & 22 & 43 \\
\hline $1997(\%)$ & 42 & 63 & 26 & 50 & 41 \\
\hline $1996(\%)$ & 10 & 5 & 7 & 23 & 9 \\
\hline Before $1996(\%)$ & 11 & 7 & 7 & 5 & 8 \\
\hline Total (valid N) & 201 & 147 & 280 & 64 & 692 \\
\hline \multicolumn{6}{|l|}{$\begin{array}{l}\text { Source of loan (\% of households with } \\
\text { loan) }\end{array}$} \\
\hline Bank (\%) & 23 & 17 & 35 & 7 & 25 \\
\hline Credit union $(\%)$ & 73 & 58 & 52 & 47 & 59 \\
\hline Relatives (\%) & 3 & 18 & 8 & 21 & 10 \\
\hline Neighbor (\%) & .. & 4 & 2 & 1 & 2 \\
\hline Others $(\%)$ & .. & 3 & 3 & 24 & 4 \\
\hline Total (valid N) & 203 & 152 & 273 & 72 & 700 \\
\hline \multicolumn{6}{|l|}{$\begin{array}{l}\text { Purpose of loan (\% of households with } \\
\text { loan) }\end{array}$} \\
\hline To buy food (\%) & 8 & 3 & 10 & 19 & 9 \\
\hline $\begin{array}{l}\text { To build, expand, or repair house } \\
(\%)\end{array}$ & 8 & 7 & 3 & 4 & 5 \\
\hline Medical treatment or medicine (\%) & 18 & 13 & 10 & 10 & 13 \\
\hline Business (\%) & 55 & 54 & 67 & 57 & 60 \\
\hline To buy equipment or appliance (\%) & 4 & 3 & 4 & 4 & 4 \\
\hline $\begin{array}{l}\text { Family social function, marriage, } \\
\text { funeral, etc. }(\%)\end{array}$ & 5 & 7 & 3 & 3 & 5 \\
\hline Others $(\%)$ & 2 & 14 & 4 & 3 & 5 \\
\hline Total (valid N) & 204 & 152 & 273 & 72 & 701 \\
\hline
\end{tabular}

.. Negligible.

Source: China Market Survey 1998. 
Table A-3: Household Energy Use for Lighting

\begin{tabular}{|c|c|c|c|c|c|}
\hline & Gansu & $\begin{array}{c}\text { Inner } \\
\text { Mongolia }\end{array}$ & Xinjiang & Qinghai & $\begin{array}{c}\text { All four } \\
\text { provinces }\end{array}$ \\
\hline \multicolumn{6}{|l|}{ Candle or butter } \\
\hline No $(\%)$ & 80 & 27 & 60 & 36 & 51 \\
\hline Yes (\%) & 20 & 73 & 40 & 64 & 49 \\
\hline Total (Valid N) & 720 & 724 & 722 & 720 & 2,886 \\
\hline \multicolumn{6}{|c|}{ Kerosene, diesel, or gasoline } \\
\hline No $(\%)$ & 1 & 65 & 14 & 52 & 33 \\
\hline Yes (\%) & 99 & 35 & 86 & 49 & 67 \\
\hline Total (Valid N) & 720 & 724 & 722 & 720 & 2886 \\
\hline \multicolumn{6}{|l|}{ Dry cell batteries } \\
\hline No $(\%)$ & 14 & 12 & 20 & 19 & 16 \\
\hline Yes (\%) & 87 & 88 & 81 & 81 & 84 \\
\hline Total (Valid N) & 705 & 718 & 719 & 720 & 2,862 \\
\hline \multicolumn{6}{|c|}{$\begin{array}{l}\text { Car batteries, generator set, or } \\
\text { community grid }\end{array}$} \\
\hline No $(\%)$ & 100 & 91 & 92 & 98 & 95 \\
\hline Yes (\%) & 0 & 9 & 8 & 2 & 5 \\
\hline Total (Valid N) & 720 & 724 & 722 & 720 & 2,886 \\
\hline \multicolumn{6}{|c|}{ PV-Wind hybrid system } \\
\hline No $(\%)$ & 100 & 100 & 100 & 100 & 100 \\
\hline Yes $(\%)$ & 0 & 0 & .. & 0 & 0 \\
\hline Total (Valid N) & 720 & 724 & 722 & 720 & 2,886 \\
\hline \multicolumn{6}{|l|}{ PV system } \\
\hline No $(\%)$ & 100 & 98 & 99 & 87 & 96 \\
\hline Yes (\%) & 0 & 2 & 1 & 13 & 4 \\
\hline Total (Valid N) & 720 & 724 & 722 & 720 & 2,886 \\
\hline \multicolumn{6}{|l|}{ Wind system } \\
\hline No $(\%)$ & 100 & 43 & 97 & 100 & 85 \\
\hline Yes $(\%)$ & 0 & 57 & 3 & 0 & 15 \\
\hline Total (Valid N) & 720 & 724 & 722 & 720 & 2,886 \\
\hline
\end{tabular}

.. Negligible.

Source: China Market Survey 1998. 
Table A-4: Households' Energy Expenditure

\begin{tabular}{|l|c|c|c|c|c|}
\hline & Gansu & $\begin{array}{c}\text { Inner } \\
\text { Mongolia }\end{array}$ & Xinjiang & Qinghai & $\begin{array}{c}\text { All four } \\
\text { provinces }\end{array}$ \\
\hline Candle or butter & 0.39 & 3.21 & 2.39 & 17.40 & 5.85 \\
Total (valid N) & 719 & 719 & 722 & 720 & 2,880 \\
Kerosene, diesel, or gasoline & 3.63 & 1.38 & 7.10 & 2.98 & 3.78 \\
Total (valid N) & 717 & 713 & 721 & 719 & 2,870 \\
Dry cell batteries & 1.68 & 5.02 & 4.66 & 4.69 & 4.02 \\
Total (valid N) & 717 & 721 & 720 & 720 & 2,878 \\
Car batteries, generator set, or & 0.07 & 3.41 & 1.82 & 0.51 & 1.46 \\
community grid & & & & & \\
Total (valid N) & 720 & 724 & 722 & 720 & 2,886 \\
Total spending & 5.79 & 13.22 & 15.98 & 25.61 & 15.17 \\
Total (valid N) & 714 & 707 & 719 & 719 & 2,859 \\
As percent of income & 5.96 & 2.62 & 3.91 & 4.65 & 4.29 \\
Total (valid N) & 714 & 707 & 719 & 719 & 2,859 \\
\hline
\end{tabular}

Source: China Market Survey 1998. 
Table A-5: Household Energy Attitude and Lighting Preferences

\begin{tabular}{|l|c|c|c|c|c|}
\hline & Gansu & $\begin{array}{c}\text { Inner } \\
\text { Mongolia }\end{array}$ & Xinjiang & Qinghai & $\begin{array}{c}\text { All four } \\
\text { provinces }\end{array}$ \\
\hline $\begin{array}{l}\text { Electricity is beneficial to production } \\
\text { activities }\end{array}$ & & & & & \\
Strongly agree (\%) & 91 & 93 & 86 & 73 & 86 \\
Agree (\%) & 5 & 6 & 12 & 23 & 11 \\
No opinion (\%) & 0 & 1 & 3 & 4 & 3 \\
Disagree (\%) & 0 & 0 & 0 & 0 & 0 \\
Strongly disagree (\%) & 719 & 713 & 719 & 0 & 0 \\
Total valid N & & & & & 2,871 \\
Because of good light, children study & & & & \\
more at night & 92 & 87 & 85 & 42 & 76 \\
Strongly agree (\%) & 6 & 11 & 12 & 36 & 16 \\
Agree (\%) & 2 & 3 & 3 & 21 & 7 \\
No opinion (\%) & 0 & 0 & 0 & 0 & 0 \\
Disagree (\%) & 0 & 0 & 0 & 0 & 0 \\
Strongly disagree (\%) & 719 & 714 & 719 & 720 & 2,872 \\
Total (valid N) & & & & & \\
Reading is easier with electric light & & & & & \\
compared to kerosene lamps & 92 & 78 & 81 & 53 & 76 \\
Strongly agree (\%) & 6 & 19 & 16 & 32 & 18 \\
Agree (\%) & 1 & 3 & 3 & 15 & 5 \\
No opinion (\%) & 0 & 0 & 0 & 0 & 0 \\
Disagree (\%) & 0 & 0 & 0 & 0 & 0 \\
Strongly disagree (\%) & 719 & 712 & 719 & 719 & 2,869 \\
Total (valid N) & & & &
\end{tabular}

Source: China Market Survey 1998. 
Table A-5: Household Energy Attitude and Lighting Preferences (continued)

\begin{tabular}{|c|c|c|c|c|c|}
\hline & Gansu & $\begin{array}{c}\text { Inner } \\
\text { Mongolia }\end{array}$ & Xinjiang & Qinghai & $\begin{array}{l}\text { All four } \\
\text { provinces }\end{array}$ \\
\hline My family feel very secure at night & & & & & \\
\hline Strongly agree $(\%)$ & 64 & 47 & 61 & 23 & 49 \\
\hline Agree $(\%)$ & 19 & 37 & 28 & 39 & 31 \\
\hline No opinion (\%) & 11 & 14 & 7 & 30 & 16 \\
\hline Disagree $(\%)$ & 6 & 2 & 4 & 7 & 5 \\
\hline Strongly disagree $(\%)$ & 1 & .. & .. & 1 & 0 \\
\hline Total (valid N) & 718 & 713 & 718 & 719 & 2,868 \\
\hline $\begin{array}{l}\text { My family is extremely happy with the } \\
\text { light we get from our current fuel }\end{array}$ & & & & & \\
\hline Strongly agree $(\%)$ & 7 & 12 & 15 & 3 & 9 \\
\hline Agree $(\%)$ & 7 & 16 & 5 & 9 & 9 \\
\hline No opinion (\%) & 3 & 8 & 10 & 10 & 8 \\
\hline Disagree $(\%)$ & 29 & 36 & 22 & 41 & 32 \\
\hline Strongly disagree (\%) & 55 & 29 & 47 & 37 & 42 \\
\hline Total (valid N) & 718 & 715 & 718 & 718 & 2,869 \\
\hline $\begin{array}{l}\text { Electricity is important for our local } \\
\text { water supply }\end{array}$ & & & & & \\
\hline Strongly agree $(\%)$ & 73 & 65 & 65 & 33 & 59 \\
\hline Agree $(\%)$ & 19 & 23 & 19 & 36 & 25 \\
\hline No opinion (\%) & 5 & 10 & 14 & 27 & 14 \\
\hline Disagree $(\%)$ & 3 & 2 & 2 & 4 & 3 \\
\hline Strongly disagree (\%) & & 0 & 0 & 0 & 0 \\
\hline Total (valid N) & 719 & 713 & 718 & 718 & 2,868 \\
\hline $\begin{array}{l}\text { Car batteries are good source of } \\
\text { electricity for lighting }\end{array}$ & & & & & \\
\hline Strongly agree $(\%)$ & 12 & 9 & 10 & 5 & 9 \\
\hline Agree $(\%)$ & 21 & 14 & 14 & 13 & 15 \\
\hline No opinion (\%) & 19 & 19 & 35 & 47 & 30 \\
\hline Disagree $(\%)$ & 44 & 49 & 29 & 29 & 38 \\
\hline Strongly disagree (\%) & 4 & 10 & 12 & 5 & 8 \\
\hline Total (valid N) & 716 & 713 & 694 & 719 & 2,842 \\
\hline$P V$ system is good source of electricity & & & & & \\
\hline for lighting & & & & & \\
\hline Strongly agree $(\%)$ & 32 & 7 & 21 & 15 & 19 \\
\hline Agree $(\%)$ & 32 & 19 & 16 & 27 & 23 \\
\hline No opinion (\%) & 26 & 45 & 43 & 45 & 40 \\
\hline Disagree $(\%)$ & 10 & 24 & 16 & 14 & 16 \\
\hline Strongly disagree $(\%)$ & 1 & 5 & 4 & 0 & 3 \\
\hline Total (valid N) & 718 & 706 & 691 & 719 & 2,834 \\
\hline $\begin{array}{l}\text { Lighting with kerosene or diesel can } \\
\text { cause health problems }\end{array}$ & & & & & \\
\hline Strongly agree $(\%)$ & 42 & 27 & 48 & 14 & 33 \\
\hline Agree $(\%)$ & 22 & 38 & 21 & 25 & 26 \\
\hline No opinion $(\%)$ & 13 & 23 & 21 & 52 & 27 \\
\hline Disagree $(\%)$ & 6 & 3 & 3 & 7 & 5 \\
\hline Strongly disagree $(\%)$ & 17 & 11 & 7 & 2 & 9 \\
\hline Total (valid N) & 719 & 708 & 719 & 719 & 2,865 \\
\hline
\end{tabular}

.. Negligible.

Source: China Market Survey 1998. 
Table A-5: Household Energy Attitude and Lighting Preferences (continued)

\begin{tabular}{|c|c|c|c|c|c|}
\hline & Gansu & $\begin{array}{c}\text { Inner } \\
\text { Mongolia } \\
\end{array}$ & Xinjiang & Qinghai & $\begin{array}{c}\text { All four } \\
\text { provinces }\end{array}$ \\
\hline \multicolumn{6}{|c|}{$\begin{array}{l}\text { It is difficult for my family to get news } \\
\text { and information }\end{array}$} \\
\hline Strongly agree $(\%)$ & 70 & 35 & 48 & 13 & 41 \\
\hline Agree $(\%)$ & 17 & 34 & 24 & 38 & 28 \\
\hline No opinion (\%) & 6 & 19 & 22 & 35 & 20 \\
\hline Disagree $(\%)$ & 1 & 7 & 4 & 14 & 7 \\
\hline Strongly disagree (\%) & 5 & 6 & 3 & 1 & 4 \\
\hline Total (valid N) & 715 & 713 & 719 & 718 & 2,865 \\
\hline \multicolumn{6}{|c|}{$\begin{array}{l}\text { Watching television would provide my } \\
\text { family with great entertainment }\end{array}$} \\
\hline Strongly agree (\%) & 76 & 70 & 67 & 32 & 61 \\
\hline Agree $(\%)$ & 20 & 26 & 16 & 34 & 24 \\
\hline No opinion (\%) & 3 & 4 & 10 & 33 & 12 \\
\hline Disagree $(\%)$ & 1 & 0 & 7 & 2 & 3 \\
\hline Strongly disagree (\%) & 0 & 0 & 0 & 0 & 0 \\
\hline Total (valid N) & 718 & 711 & 719 & 719 & 2,867 \\
\hline \multicolumn{6}{|c|}{$\begin{array}{l}\text { Television takes study time away from } \\
\text { children }\end{array}$} \\
\hline Strongly agree $(\%)$ & 26 & 29 & 7 & 7 & 17 \\
\hline Agree $(\%)$ & 40 & 42 & 22 & 27 & 33 \\
\hline No opinion (\%) & 19 & 8 & 29 & 55 & 28 \\
\hline Disagree $(\%)$ & 14 & 12 & 32 & 10 & 17 \\
\hline Strongly disagree (\%) & 1 & 9 & 10 & 1 & 5 \\
\hline Total (valid N) & 719 & 709 & 718 & 719 & 2,865 \\
\hline \multicolumn{6}{|c|}{$\begin{array}{l}\text { I complete work in my house during the } \\
\text { evening after it is dark outside }\end{array}$} \\
\hline Strongly agree $(\%)$ & 37 & 32 & 34 & 29 & 33 \\
\hline Agree $(\%)$ & 44 & 45 & 30 & 43 & 41 \\
\hline No opinion (\%) & 4 & 7 & 8 & 5 & 6 \\
\hline Disagree (\%) & 12 & 11 & 13 & 12 & 12 \\
\hline Strongly disagree (\%) & 3 & 5 & 15 & 11 & 9 \\
\hline Total (valid N) & 712 & 717 & 660 & 719 & 2,808 \\
\hline \multicolumn{6}{|c|}{$\begin{array}{l}\text { We often receive friends, relatives, or } \\
\text { neighbors visiting us in the evening after } \\
\text { it is dark outside }\end{array}$} \\
\hline Strongly agree (\%) & 27 & 34 & 35 & 23 & 30 \\
\hline Agree $(\%)$ & 59 & 44 & 45 & 52 & 50 \\
\hline No opinion (\%) & 3 & 3 & 6 & 5 & 4 \\
\hline Disagree (\%) & 7 & 14 & 10 & 16 & 12 \\
\hline Strongly disagree (\%) & 4 & 6 & 4 & 6 & 5 \\
\hline Total (valid N) & 713 & 717 & 718 & 719 & 2,867 \\
\hline \multicolumn{6}{|c|}{$\begin{array}{l}\text { Today life is better than it was five years } \\
\text { ago }\end{array}$} \\
\hline Strongly agree $(\%)$ & 68 & 74 & 55 & 56 & 63 \\
\hline Agree $(\%)$ & 30 & 21 & 33 & 38 & 30 \\
\hline No opinion (\%) & 1 & 4 & 6 & 4 & 4 \\
\hline Disagree (\%) & 1 & 1 & 4 & 2 & 2 \\
\hline Strongly disagree (\%) & 1 & 0 & 1 & 0 & 1 \\
\hline
\end{tabular}


Total (valid N)

717

717

718

719

2,871

Source: China Market Survey 1998. 
Table A-5: Household Energy Attitude and Lighting Preferences (continued)

\begin{tabular}{|c|c|c|c|c|c|}
\hline & Gansu & $\begin{array}{c}\text { Inner } \\
\text { Mongolia }\end{array}$ & Xinjiang & Qinghai & $\begin{array}{l}\text { All four } \\
\text { provinces }\end{array}$ \\
\hline \multicolumn{6}{|l|}{$\begin{array}{l}\text { I am optimistic that life will get better in } \\
\text { the future }\end{array}$} \\
\hline Strongly agree $(\%)$ & 74 & 69 & 62 & 51 & 64 \\
\hline Agree (\%) & 17 & 24 & 17 & 31 & 22 \\
\hline No opinion $(\%)$ & 10 & 6 & 21 & 17 & 13 \\
\hline Disagree $(\%)$ & .. & 1 & 0 & 1 & 1 \\
\hline Strongly disagree $(\%)$ & .. & .. & 0 & .. & 0 \\
\hline Total (valid N) & 718 & 717 & 718 & 719 & 2,872 \\
\hline \multicolumn{6}{|l|}{$\begin{array}{l}\text { I prefer to pay cash for my major } \\
\text { purchase }\end{array}$} \\
\hline Strongly agree $(\%)$ & 60 & 39 & 41 & 36 & 44 \\
\hline Agree (\%) & 13 & 40 & 26 & 43 & 31 \\
\hline No opinion $(\%)$ & 18 & 13 & 16 & 13 & 15 \\
\hline Disagree $(\%)$ & 8 & 7 & 13 & 7 & 9 \\
\hline Strongly disagree $(\%)$ & 2 & 1 & 3 & 0 & 2 \\
\hline Total (valid N) & 717 & 714 & 718 & 719 & 2,868 \\
\hline \multicolumn{6}{|l|}{$\begin{array}{l}\text { Light at night is useful to keep the herd } \\
\text { together }\end{array}$} \\
\hline Strongly agree $(\%)$ & 49 & 39 & 46 & 26 & 40 \\
\hline Agree (\%) & 17 & 28 & 20 & 29 & 24 \\
\hline No opinion $(\%)$ & 28 & 18 & 22 & 34 & 25 \\
\hline Disagree $(\%)$ & 6 & 11 & 10 & 8 & 9 \\
\hline Strongly disagree $(\%)$ & 1 & 5 & 3 & 3 & 3 \\
\hline Total (valid N) & 630 & 711 & 713 & 717 & 2,771 \\
\hline
\end{tabular}

.. Negligible.

Source: China Market Survey 1998. 
Table A-6: Households that Have Heard about or Have Seen 20-Watt Photovoltaic Systems (percent)

\begin{tabular}{|l|c|c|c|c|c|}
\hline & Gansu & $\begin{array}{c}\text { Inner } \\
\text { Mongolia }\end{array}$ & Xinjiang & Qinghai & $\begin{array}{c}\text { All four } \\
\text { provinces }\end{array}$ \\
\hline $\begin{array}{l}\text { Have heard about or have seen 20-watt } \\
\text { PV system }\end{array}$ & 45 & 39 & 34 & 31 & 37 \\
$\quad \begin{array}{l}\text { Never heard of it (\%) } \\
\quad \text { Have heard about it from newspaper } \\
\text { or magazine (\%) }\end{array}$ & 21 & 5 & 15 & 1 & 11 \\
$\quad \begin{array}{l}\text { Have heard about it from radio, } \\
\text { television (\%) }\end{array}$ & 24 & 32 & 36 & 41 & 33 \\
$\quad \begin{array}{l}\text { Have heard about it from neighbors } \\
\text { or friends (\%) }\end{array}$ & 7 & 12 & 10 & 18 & 2 \\
$\quad \begin{array}{l}\text { Have seen it in store (\%) } \\
\text { Have seen a system installed at } \\
\text { friend's, government's or neighbor's }\end{array}$ & .. & 1 & 0 & 0 & 0 \\
$\quad \begin{array}{l}\text { Have heard or seen it from other } \\
\text { sources (\%) }\end{array}$ & 704 & 689 & 596 & 616 & 2,605
\end{tabular}

.. Negligible.

Source: China Market Survey 1998.

Table A-7: Households That Are Interested in Buying 20-Watt Photovoltaic Systems (percent)

\begin{tabular}{|c|c|c|c|c|c|}
\hline & Gansu & $\begin{array}{c}\text { Inner } \\
\text { Mongolia }\end{array}$ & Xinjiang & Qinghai & $\begin{array}{l}\text { All four } \\
\text { provinces }\end{array}$ \\
\hline $\begin{array}{l}\text { Household interested in buying a } 20- \\
\text { watt } P V \text { system with cash, about } Y 1,700\end{array}$ & & & & & \\
\hline No $(\%)$ & 34 & 71 & 47 & 40 & 48 \\
\hline Yes, but no money (\%) & 42 & 16 & 38 & 41 & 34 \\
\hline Yes $(\%)$ & 24 & 14 & 16 & 19 & 18 \\
\hline Total (valid N) & 699 & 699 & 588 & 554 & 2,540 \\
\hline $\begin{array}{l}\text { Household interested in buying a } 20 \text { - } \\
\text { watt } P V \text { system with cash down payment } \\
\text { and one year credit }\end{array}$ & & & & & \\
\hline No $(\%)$ & 48 & 80 & 55 & 53 & 60 \\
\hline Yes, but no money (\%) & 46 & 18 & 38 & 42 & 35 \\
\hline Yes $(\%)$ & 6 & 2 & 7 & 4 & 5 \\
\hline Total (valid N) & 492 & 554 & 471 & 415 & 1,932 \\
\hline
\end{tabular}

Source: China Market Survey 1998. 
Table A-8: Reason for Not Being Interested in Purchasing 20-Watt Photovoltaic Systems

\begin{tabular}{|c|c|c|c|c|c|}
\hline & Gansu & $\begin{array}{c}\text { Inner } \\
\text { Mongolia }\end{array}$ & Xinjiang & Qinghai & $\begin{array}{l}\text { All four } \\
\text { provinces }\end{array}$ \\
\hline \multicolumn{6}{|l|}{ Don't know about the system } \\
\hline No reason $(\%)$ & 66 & 71 & 62 & 53 & 63 \\
\hline Main reason $(\%)$ & 19 & 14 & 30 & 27 & 22 \\
\hline Secondary reason $(\%)$ & 15 & 15 & 8 & 21 & 15 \\
\hline Total (valid N) & 378 & 430 & 369 & 372 & 1,549 \\
\hline \multicolumn{6}{|l|}{ System cost too much } \\
\hline No reason $(\%)$ & 27 & 54 & 17 & 36 & 34 \\
\hline Main reason $(\%)$ & 58 & 32 & 69 & 56 & 53 \\
\hline Secondary reason $(\%)$ & 15 & 14 & 14 & 9 & 13 \\
\hline Total (valid N) & 429 & 449 & 371 & 374 & 1,623 \\
\hline \multicolumn{6}{|c|}{ No convenient location to buy } \\
\hline No reason $(\%)$ & 67 & 71 & 69 & 60 & 67 \\
\hline Main reason $(\%)$ & 12 & 5 & 8 & 19 & 11 \\
\hline Secondary reason $(\%)$ & 21 & 24 & 23 & 20 & 22 \\
\hline Total (valid N) & 347 & 424 & 329 & 358 & 1,458 \\
\hline \multicolumn{6}{|c|}{ Can't get credit to buy system } \\
\hline No reason $(\%)$ & 57 & 72 & 38 & 53 & 56 \\
\hline Main reason $(\%)$ & 18 & 8 & 41 & 29 & 23 \\
\hline Secondary reason $(\%)$ & 25 & 20 & 21 & 18 & 21 \\
\hline Total (valid N) & 352 & 429 & 337 & 353 & 1,471 \\
\hline \multicolumn{6}{|c|}{$\begin{array}{l}\text { Worry about quality, services, not easy } \\
\text { to operate, etc. }\end{array}$} \\
\hline No reason $(\%)$ & 72 & 59 & 34 & 48 & 54 \\
\hline Main reason $(\%)$ & 10 & 23 & 21 & 30 & 21 \\
\hline Secondary reason $(\%)$ & 18 & 18 & 45 & 22 & 25 \\
\hline Total (valid N) & 377 & 430 & 351 & 336 & 1,494 \\
\hline \multicolumn{6}{|c|}{$\begin{array}{l}\text { Have had electric supply, or small wind, } \\
\text { or small electric generator set }\end{array}$} \\
\hline No reason $(\%)$ & 91 & 59 & 79 & 93 & 78 \\
\hline Main reason $(\%)$ & 6 & 26 & 12 & 2 & 13 \\
\hline Secondary reason $(\%)$ & 4 & 16 & 9 & 6 & 9 \\
\hline Total (valid N) & 340 & 504 & 343 & 335 & 1,522 \\
\hline \multicolumn{6}{|c|}{$\begin{array}{l}\text { Will get grid connection or will buy } \\
\text { small electric generator set }\end{array}$} \\
\hline No reason $(\%)$ & 82 & 76 & 71 & 86 & 78 \\
\hline Main reason $(\%)$ & 14 & 17 & 23 & 8 & 16 \\
\hline Secondary reason $(\%)$ & 4 & 7 & 6 & 6 & 6 \\
\hline Total (valid N) & 352 & 430 & 329 & 333 & 1,444 \\
\hline \multicolumn{6}{|c|}{$\begin{array}{l}\text { Capacity of the system is not enough for } \\
\text { the family to use }\end{array}$} \\
\hline No reason $(\%)$ & 46 & 53 & 85 & 72 & 62 \\
\hline Main reason $(\%)$ & 52 & 42 & 8 & 17 & 32 \\
\hline Secondary reason $(\%)$ & 2 & 5 & 7 & 12 & 6 \\
\hline Total (valid N) & 407 & 479 & 333 & 339 & 1,558 \\
\hline
\end{tabular}

Source: China Market Survey 1998. 
Table A-9: Households That Have Heard about or Have Seen 50-Watt Photovoltaic Systems (percent)

\begin{tabular}{|c|c|c|c|c|c|}
\hline & Gansu & $\begin{array}{c}\text { Inner } \\
\text { Mongolia } \\
\end{array}$ & Xinjiang & Qinghai & $\begin{array}{c}\text { All four } \\
\text { provinces }\end{array}$ \\
\hline $\begin{array}{l}\text { Have heard about or have seen } 50 \text {-watt } \\
P V \text { system }\end{array}$ & & & & & \\
\hline Never heard of it (\%) & 44 & 46 & 38 & 39 & 42 \\
\hline $\begin{array}{l}\text { Have heard about it from newspaper } \\
\text { or magazine }(\%)\end{array}$ & 27 & 7 & 14 & 7 & 15 \\
\hline $\begin{array}{l}\text { Have heard about it from radio, } \\
\text { television }(\%)\end{array}$ & 1 & 4 & 4 & 6 & 3 \\
\hline $\begin{array}{l}\text { Have heard about it from neighbors } \\
\text { or friends }(\%)\end{array}$ & 24 & 36 & 27 & 40 & 31 \\
\hline Have seen it in store $(\%)$ & 0 & 2 & 0 & 1 & 1 \\
\hline $\begin{array}{l}\text { Have seen a system installed at } \\
\text { friend's, government's or neighbor's } \\
(\%)\end{array}$ & 4 & 4 & 18 & 8 & 7 \\
\hline $\begin{array}{l}\text { Have heard or seen it from other } \\
\text { sources }(\%)\end{array}$ & .. & .. & .. & 0 & 0 \\
\hline Total valid N & 502 & 343 & 245 & 348 & 1,438 \\
\hline
\end{tabular}

.. Negligible.

Source: China Market Survey 1998. 
Table A-10: Households That Are Interested in Buying 50-Watt Photovoltaic Systems (percent)

\begin{tabular}{|c|c|c|c|c|c|}
\hline & Gansu & $\begin{array}{c}\text { Inner } \\
\text { Mongolia }\end{array}$ & Xinjiang & Qinghai & $\begin{array}{c}\text { All four } \\
\text { provinces }\end{array}$ \\
\hline \multicolumn{6}{|l|}{ Household interested in buying a 50- } \\
\hline Watt $P V$ system with cash, about $Y 3,800$ & & & & & \\
\hline No $(\%)$ & 33 & 64 & 31 & 38 & 42 \\
\hline Yes, but no money (\%) & 43 & 10 & 35 & 37 & 32 \\
\hline Yes $(\%)$ & 24 & 26 & 34 & 25 & 26 \\
\hline Total (valid N) & 495 & 347 & 233 & 329 & 1,404 \\
\hline \multirow{2}{*}{\multicolumn{6}{|c|}{$\begin{array}{l}\text { Household interested in buying a } 50 \text { - } \\
\text { Watt PV system with cash down payment } \\
\text { and one year credit }\end{array}$}} \\
\hline & & & & & \\
\hline No $(\%)$ & 38 & 92 & 44 & 48 & 54 \\
\hline Yes, but no money (\%) & 58 & 4 & 48 & 47 & 41 \\
\hline Yes $(\%)$ & 4 & 5 & 8 & 5 & 5 \\
\hline Total (valid N) & 340 & 224 & 147 & 229 & 940 \\
\hline
\end{tabular}

Source: China Market Survey 1998. 
Table A-11: Reason for Not Being Interested in Purchasing 50-Watt Photovoltaic Systems

\begin{tabular}{|c|c|c|c|c|c|}
\hline & Gansu & $\begin{array}{c}\text { Inner } \\
\text { Mongolia }\end{array}$ & Xinjiang & Qinghai & $\begin{array}{l}\text { All four } \\
\text { provinces }\end{array}$ \\
\hline \multicolumn{6}{|l|}{ Don't know about the system } \\
\hline No reason $(\%)$ & 67 & 82 & 49 & 66 & 68 \\
\hline Main reason $(\%)$ & 25 & 4 & 44 & 21 & 21 \\
\hline Secondary reason $(\%)$ & 7 & 14 & 7 & 14 & 11 \\
\hline Total (valid N) & 232 & 144 & 69 & 148 & 593 \\
\hline \multicolumn{6}{|l|}{ System cost too тисh } \\
\hline No reason $(\%)$ & 31 & 58 & 11 & 24 & 34 \\
\hline Main reason $(\%)$ & 59 & 27 & 74 & 67 & 55 \\
\hline Secondary reason $(\%)$ & 10 & 16 & 15 & 9 & 12 \\
\hline Total (valid N) & 295 & 181 & 86 & 152 & 714 \\
\hline \multicolumn{6}{|c|}{ No convenient location to buy } \\
\hline No reason $(\%)$ & 70 & 80 & 47 & 66 & 69 \\
\hline Main reason $(\%)$ & 19 & 1 & 27 & 11 & 13 \\
\hline Secondary reason $(\%)$ & 10 & 18 & 27 & 23 & 17 \\
\hline Total (valid N) & 201 & 141 & 49 & 142 & 533 \\
\hline \multicolumn{6}{|c|}{ Can't get credit to buy system } \\
\hline No reason $(\%)$ & 57 & 93 & 26 & 61 & 64 \\
\hline Main reason $(\%)$ & 15 & 3 & 54 & 24 & 18 \\
\hline Secondary reason $(\%)$ & 28 & 4 & 19 & 15 & 17 \\
\hline Total (valid N) & 206 & 141 & 57 & 141 & 545 \\
\hline \multicolumn{6}{|c|}{$\begin{array}{l}\text { Worry about quality, services, not easy } \\
\text { to operate, etc. }\end{array}$} \\
\hline No reason $(\%)$ & 68 & 59 & 26 & 48 & 56 \\
\hline Main reason $(\%)$ & 14 & 8 & 40 & 33 & 20 \\
\hline Secondary reason $(\%)$ & 18 & 33 & 34 & 19 & 24 \\
\hline Total (valid N) & 228 & 141 & 62 & 144 & 575 \\
\hline \multicolumn{6}{|c|}{$\begin{array}{l}\text { Have had electric supply, or small wind, } \\
\text { or small electric generator set. }\end{array}$} \\
\hline No reason $(\%)$ & 91 & 45 & 51 & 94 & 74 \\
\hline Main reason (\%) & 9 & 20 & 4 & 2 & 10 \\
\hline Secondary reason $(\%)$ & 1 & 35 & 45 & 4 & 16 \\
\hline Total (valid N) & 192 & 168 & 49 & 151 & 560 \\
\hline \multicolumn{6}{|c|}{ Will get grid connection or will buy } \\
\hline small electric generator se & & & & & \\
\hline No reason $(\%)$ & 85 & 89 & 44 & 97 & 86 \\
\hline Main reason $(\%)$ & 15 & 8 & 32 & .. & 11 \\
\hline Secondary reason $(\%)$ & 1 & 3 & 24 & 3 & 4 \\
\hline Total (valid N) & 199 & 145 & 50 & 149 & 543 \\
\hline \multicolumn{6}{|c|}{$\begin{array}{l}\text { Capacity of the system is not enough for } \\
\text { the family to use }\end{array}$} \\
\hline No reason $(\%)$ & 32 & 6 & 46 & 79 & 37 \\
\hline Main reason $(\%)$ & 68 & 93 & 40 & 17 & 61 \\
\hline Secondary reason $(\%)$ & 0 & 1 & 14 & 3 & 2 \\
\hline Total (valid N) & 255 & 172 & 50 & 149 & 626 \\
\hline
\end{tabular}

.. Negligible.

Source: China Market Survey 1998. 
Table A-12: Households That Have Heard about or Have Seen Small Hybrid Photovoltaic-Wind Systems (percent)

\begin{tabular}{|c|c|c|c|c|c|}
\hline & Gansu & $\begin{array}{c}\text { Inner } \\
\text { Mongolia }\end{array}$ & Xinjiang & Qinghai & $\begin{array}{c}\text { All four } \\
\text { provinces }\end{array}$ \\
\hline \multicolumn{6}{|l|}{$\begin{array}{l}\text { Have heard about or have seen small } \\
\text { hybrid } P V \text {-wind system }\end{array}$} \\
\hline Never heard of it $(\%)$ & 71 & 61 & 65 & 73 & 68 \\
\hline $\begin{array}{l}\text { Have heard about it from newspaper } \\
\text { or magazine }(\%)\end{array}$ & 16 & 5 & 9 & 2 & 8 \\
\hline $\begin{array}{l}\text { Have heard about it from radio, } \\
\text { television }(\%)\end{array}$ & 2 & 3 & 3 & 5 & 3 \\
\hline $\begin{array}{l}\text { Have heard about it from neighbors } \\
\text { or friends }(\%)\end{array}$ & 10 & 23 & 21 & 18 & 18 \\
\hline Have seen it in store $(\%)$ & 0 & 2 & 0 & 1 & 1 \\
\hline $\begin{array}{l}\text { Have seen a system installed at } \\
\text { friend's, government's or neighbor's } \\
(\%)\end{array}$ & 2 & 6 & 3 & 1 & 3 \\
\hline $\begin{array}{l}\text { Have heard or seen it from other } \\
\text { sources }(\%)\end{array}$ & .. & .. & .. & .. & .. \\
\hline Total valid $\mathrm{N}$ & 673 & 667 & 529 & 657 & 2,526 \\
\hline \multicolumn{6}{|l|}{$\begin{array}{l}\text { Household interested in buying hybrid } \\
P V \text {-wind system with cash }\end{array}$} \\
\hline No $(\%)$ & 46 & 36 & 65 & 57 & 50 \\
\hline Yes, but no money (\%) & 35 & 31 & 27 & 25 & 30 \\
\hline Yes $(\%)$ & 19 & 33 & 8 & 18 & 20 \\
\hline Total (valid N) & 667 & 655 & 518 & 607 & 2,447 \\
\hline \multicolumn{6}{|l|}{$\begin{array}{l}\text { Household interested in buying a hybrid } \\
P V \text {-wind system with cash down } \\
\text { payment and credit }\end{array}$} \\
\hline No $(\%)$ & 55 & 51 & 67 & 64 & 59 \\
\hline Yes, but no money (\%) & 42 & 44 & 29 & 28 & 36 \\
\hline Yes $(\%)$ & 3 & 5 & 5 & 8 & 5 \\
\hline Total (valid N) & 531 & 421 & 468 & 493 & 1,913 \\
\hline
\end{tabular}

.. Negligible.

Source: China Market Survey 1998. 
Table A-13: Reason for Not Being Interested in Purchasing Hybrid PhotovoltaicWind Systems

\begin{tabular}{|c|c|c|c|c|c|}
\hline & Gansu & $\begin{array}{c}\text { Inner } \\
\text { Mongolia }\end{array}$ & Xinjiang & Qinghai & $\begin{array}{l}\text { All four } \\
\text { provinces }\end{array}$ \\
\hline \multicolumn{6}{|l|}{ Don't know about the system } \\
\hline No reason $(\%)$ & 63 & 64 & 42 & 36 & 51 \\
\hline Main reason $(\%)$ & 22 & 24 & 46 & 48 & 35 \\
\hline Secondary reason $(\%)$ & 15 & 12 & 13 & 16 & 14 \\
\hline Total (valid N) & 450 & 367 & 385 & 418 & 1,620 \\
\hline \multicolumn{6}{|l|}{ System cost too тисh } \\
\hline No reason $(\%)$ & 34 & 49 & 19 & 38 & 35 \\
\hline Main reason $(\%)$ & 58 & 39 & 63 & 53 & 54 \\
\hline Secondary reason $(\%)$ & 8 & 12 & 18 & 9 & 11 \\
\hline Total (valid N) & 489 & 363 & 364 & 400 & 1,616 \\
\hline \multicolumn{6}{|c|}{ No convenient location to buy } \\
\hline No reason $(\%)$ & 75 & 70 & 71 & 66 & 71 \\
\hline Main reason $(\%)$ & 10 & 4 & 7 & 18 & 10 \\
\hline Secondary reason $(\%)$ & 15 & 27 & 23 & 17 & 20 \\
\hline Total (valid N) & 418 & 354 & 320 & 392 & 1,484 \\
\hline \multicolumn{6}{|c|}{ Can't get credit to buy system } \\
\hline No reason $(\%)$ & 65 & 70 & 49 & 61 & 62 \\
\hline Main reason $(\%)$ & 16 & 6 & 30 & 28 & 20 \\
\hline Secondary reason $(\%)$ & 19 & 24 & 21 & 12 & 19 \\
\hline Total (valid N) & 414 & 360 & 326 & 391 & 1,491 \\
\hline \multicolumn{6}{|c|}{$\begin{array}{l}\text { Worry about quality, services, not easy } \\
\text { to operate, etc. }\end{array}$} \\
\hline No reason $(\%)$ & 73 & 52 & 47 & 51 & 57 \\
\hline Main reason $(\%)$ & 9 & 32 & 22 & 28 & 22 \\
\hline Secondary reason $(\%)$ & 18 & 16 & 31 & 21 & 21 \\
\hline Total (valid N) & 445 & 360 & 333 & 389 & 1,527 \\
\hline \multicolumn{6}{|c|}{$\begin{array}{l}\text { Have had electric supply, or small wind, } \\
\text { or small electric generator set }\end{array}$} \\
\hline No reason $(\%)$ & 90 & 66 & 84 & 93 & 83 \\
\hline Main reason $(\%)$ & 4 & 20 & 11 & 1 & 9 \\
\hline Secondary reason $(\%)$ & 5 & 14 & 6 & 7 & 8 \\
\hline Total (Valid N) & 408 & 389 & 335 & 387 & 1,519 \\
\hline \multicolumn{6}{|c|}{$\begin{array}{l}\text { Will get grid connection or will buy } \\
\text { small electric generator set }\end{array}$} \\
\hline No reason $(\%)$ & 85 & 76 & 77 & 87 & 82 \\
\hline Main reason $(\%)$ & 10 & 17 & 18 & 7 & 12 \\
\hline Secondary reason $(\%)$ & 5 & 7 & 5 & 6 & 6 \\
\hline Total (valid N) & 409 & 354 & 323 & 390 & 1,476 \\
\hline \multicolumn{6}{|c|}{$\begin{array}{l}\text { Capacity of the system is not enough for } \\
\text { the family to use }\end{array}$} \\
\hline No reason $(\%)$ & 78 & 94 & 87 & 79 & 84 \\
\hline Main reason $(\%)$ & 16 & 1 & 4 & 7 & 7 \\
\hline Secondary reason $(\%)$ & 6 & 5 & 9 & 14 & 9 \\
\hline Total (valid N) & 408 & 350 & 325 & 396 & 1,479 \\
\hline
\end{tabular}

Source: China Market Survey 1998. 
Table A-14: Photovoltaic Systems Owned by Households

\begin{tabular}{|l|c|c|c|c|c|}
\hline & Gansu & $\begin{array}{c}\text { Inner } \\
\text { Mongolia }\end{array}$ & Xinjiang & Qinghai & $\begin{array}{c}\text { All four } \\
\text { provinces }\end{array}$ \\
\hline Number of PV systems owned & & & & & \\
None (\%) & 100 & 98 & 99 & 87 & 96 \\
One (\%) & 0.1 & 2 & 0.6 & 13 & 4 \\
Total (valid N) & 720 & 724 & 722 & 720 & 2,886
\end{tabular}

Source: China Market Survey 1998.

Table A-15: Attitude toward Photovoltaic Systems among System Owners

\begin{tabular}{|c|c|c|c|c|c|}
\hline & Gansu & $\begin{array}{c}\text { Inner } \\
\text { Mongolia } \\
\end{array}$ & Xinjiang & Qinghai & $\begin{array}{c}\text { All four } \\
\text { provinces }\end{array}$ \\
\hline \multicolumn{6}{|l|}{$\begin{array}{l}\text { What do you think about the price of } P V \\
\text { system? }\end{array}$} \\
\hline Very expensive $(\%)$ & 7 & .. & .. & 8 & 6 \\
\hline Expensive (\%) & 40 & 14 & 75 & 64 & 58 \\
\hline Right price (\%) & 53 & 71 & 19 & 24 & 31 \\
\hline Cheap (\%) & .. & 14 & 6 & 3 & 4 \\
\hline Total (valid N) & 15 & 14 & 16 & 95 & 140 \\
\hline \multicolumn{6}{|l|}{$\begin{array}{l}\text { Electricity generated from the PV system } \\
\text { is: }\end{array}$} \\
\hline Not enough for household need (\%) & 38 & 67 & 13 & 39 & 38 \\
\hline Just enough for household need (\%) & 25 & 25 & 67 & 48 & 46 \\
\hline $\begin{array}{l}\text { More than enough for household } \\
\text { need }(\%)\end{array}$ & 38 & 8 & 20 & 13 & 16 \\
\hline Total (valid N) & 16 & 12 & 15 & 95 & 138 \\
\hline
\end{tabular}

Note: Because of a small number of owners of photovoltaic systems in Gansu and Xinjiang selected through the random sampling procedure, additional households that owned photovoltaic systems were purposively selected to develop a profile of photovoltaic system owners. Therefore, statistical inferences cannot be drawn for Gansu and Xinjiang.

.. Negligible.

Source: China Market Survey 1998. 
Table A-16: Reasons for Photovoltaic System Owners to Obtain Systems

\begin{tabular}{|c|c|c|c|c|c|}
\hline & Gansu & $\begin{array}{c}\text { Inner } \\
\text { Mongolia }\end{array}$ & Xinjiang & Qinghai & $\begin{array}{l}\text { All four } \\
\text { provinces }\end{array}$ \\
\hline \multicolumn{6}{|l|}{ For children education } \\
\hline No reason $(\%)$ & 15 & & & 41 & 31 \\
\hline Main reason $(\%)$ & 46 & 18 & 33 & 17 & 22 \\
\hline Secondary reason $(\%)$ & 39 & 82 & 67 & 41 & 47 \\
\hline Total (valid N) & 13 & 11 & 12 & 87 & 123 \\
\hline \multicolumn{6}{|l|}{ For better lighting } \\
\hline No reason $(\%)$ & .. & .. & .. & 3 & 2 \\
\hline Main reason $(\%)$ & 100 & 100 & 93 & 89 & 92 \\
\hline Secondary reason $(\%)$ & .. & .. & 7 & 8 & 6 \\
\hline Total (valid N) & 15 & 12 & 15 & 93 & 135 \\
\hline \multicolumn{6}{|l|}{ To watch television } \\
\hline No reason $(\%)$ & 20 & .. & 18 & 79 & 62 \\
\hline Main reason $(\%)$ & 80 & & 27 & 6 & 14 \\
\hline Secondary reason $(\%)$ & .. & 100 & 55 & 15 & 25 \\
\hline Total (valid N) & 10 & 10 & 11 & 86 & 117 \\
\hline $\begin{array}{l}P V \text { system is cheaper than kerosene \& } \\
\text { other fuels }\end{array}$ & & & & & \\
\hline No reason $(\%)$ & 46 & 67 & 40 & 24 & 31 \\
\hline Main reason $(\%)$ & 9 & .. & 40 & 34 & 29 \\
\hline Secondary reason $(\%)$ & 46 & 33 & 20 & 42 & 40 \\
\hline Total (valid N) & 11 & 9 & 10 & 86 & 116 \\
\hline
\end{tabular}

Note: Because of a small number of owners of photovoltaic systems in Gansu and Xinjiang selected through the random sampling procedure, additional households that owned photovoltaic systems were purposively selected to develop a profile of photovoltaic system owners. Therefore, statistical inferences cannot be drawn for Gansu and Xinjiang.

.. Negligible.

Source: China Market Survey 1998. 


\section{Table A-17: Perceived Benefits of Photovoltaic Systems among System Owners}

\begin{tabular}{|c|c|c|c|c|c|}
\hline $\begin{array}{l}\text { Greatest benefits of PV system to my } \\
\text { family is: }\end{array}$ & Gansu & $\begin{array}{c}\text { Inner } \\
\text { Mongolia }\end{array}$ & Xinjiang & Qinghai & $\begin{array}{l}\text { All four } \\
\text { provinces }\end{array}$ \\
\hline $\begin{array}{l}\text { Access to news and information from } \\
\text { television and radio }\end{array}$ & & & & & \\
\hline No reason $(\%)$ & 10 & .. & 8 & 43 & 32 \\
\hline Main reason $(\%)$ & 60 & 17 & 25 & 26 & 28 \\
\hline Secondary reason $(\%)$ & 30 & 83 & 67 & 31 & 40 \\
\hline Total (valid N) & 10 & 12 & 12 & 87 & 121 \\
\hline Provide lighting for my family & & & & & \\
\hline No reason $(\%)$ & .. & .. & .. & 3 & 2 \\
\hline Main reason $(\%)$ & 100 & 92 & 100 & 81 & 86 \\
\hline Secondary reason $(\%)$ & .. & 8 & .. & 16 & 12 \\
\hline Total (valid N) & 16 & 12 & 16 & 95 & 139 \\
\hline $\begin{array}{l}\text { Getting entertainment from television, } \\
\text { radio, and tape }\end{array}$ & & & & & \\
\hline No reason $(\%)$ & .. & .. & .. & 30 & 21 \\
\hline Main reason $(\%)$ & 77 & & 50 & 24 & 30 \\
\hline Secondary reason $(\%)$ & 23 & 100 & 50 & 46 & 49 \\
\hline Total (valid N) & 13 & 12 & 14 & 89 & 128 \\
\hline $\begin{array}{l}\text { Enabling family members to read, write, } \\
\text { and study in the evening longer than } \\
\text { before }\end{array}$ & & & & & \\
\hline No reason $(\%)$ & .. & .. & 9 & 25 & 18 \\
\hline Main reason $(\%)$ & 50 & 50 & 46 & 30 & 35 \\
\hline Secondary reason $(\%)$ & 50 & 50 & 46 & 46 & 46 \\
\hline Total (valid N) & 14 & 12 & 11 & 88 & 125 \\
\hline Enabling us to do more work & & & & & \\
\hline No reason $(\%)$ & 43 & 27 & 31 & 17 & 22 \\
\hline Main reason $(\%)$ & 36 & 18 & 15 & 55 & 45 \\
\hline Secondary reason $(\%)$ & 21 & 55 & 54 & 28 & 33 \\
\hline Total (valid N) & 14 & 11 & 13 & 88 & 126 \\
\hline
\end{tabular}

Note: Because of a small number of owners of photovoltaic systems in Gansu and Xinjiang selected through the random sampling procedure, additional households that owned photovoltaic systems were purposively selected to develop a profile of photovoltaic system owners. Therefore, statistical inferences cannot be drawn for Gansu and Xinjiang.

.. Negligible.

Source: China Market Survey 1998. 
Table A-18: Attitude of Photovoltaic System Owners toward System Performance

\begin{tabular}{|c|c|c|c|c|c|}
\hline & Gansu & $\begin{array}{c}\text { Inner } \\
\text { Mongolia }\end{array}$ & Xinjiang & Qinghai & $\begin{array}{l}\text { All four } \\
\text { provinces }\end{array}$ \\
\hline $\begin{array}{l}\text { Satisfied with the performance of the } \\
\text { system }\end{array}$ & & & & & \\
\hline High (\%) & 69 & 8 & 44 & 10 & 20 \\
\hline Rather High (\%) & .. & 25 & 25 & 21 & 19 \\
\hline Fair (\%) & 19 & 67 & 31 & 63 & 55 \\
\hline Rather low (\%) & 6 & .. & .. & 6 & 5 \\
\hline Low $(\%)$ & 6 & .. & .. & .. & 1 \\
\hline Total valid N & 16 & 12 & 16 & 95 & 139 \\
\hline $\begin{array}{l}\text { Would recommend } P V \text { system to } \\
\text { relatives and friends }\end{array}$ & & & & & \\
\hline Yes $(\%)$ & 6 & 38 & 13 & 17 & 16 \\
\hline No $(\%)$ & 94 & 63 & 88 & 83 & 84 \\
\hline Total (valid N) & 16 & 8 & 16 & 96 & 136 \\
\hline
\end{tabular}

Note: Because of a small number of owners of photovoltaic systems in Gansu and Xinjiang selected through the random sampling procedure, additional households that owned photovoltaic systems were purposively selected to develop a profile of photovoltaic system owners. Therefore, statistical inferences cannot be drawn for Gansu and Xinjiang.

.. Negligible.

Source: China Market Survey 1998. 
Table A-19: Changes in Lifestyles of Photovoltaic System Owners

\begin{tabular}{|l|c|c|c|c|c|}
\hline & Gansu & $\begin{array}{c}\text { Inner } \\
\text { Mongolia }\end{array}$ & Xinjiang & Qinghai & $\begin{array}{c}\text { All four } \\
\text { provinces }\end{array}$ \\
\hline $\begin{array}{l}\text { After installing PV systems, family stays } \\
\text { up later than before }\end{array}$ & & & & \\
$\quad$ Go to bed at the same time as before & 6 & 27 & 31 & 19 & 20 \\
$\quad(\%)$ & 94 & 73 & 69 & 81 & 80 \\
$\quad$ Stay up later (\%) & 16 & 11 & 16 & 95 & 138 \\
Total valid n
\end{tabular}

Note: Because of a small number of owners of photovoltaic systems in Gansu and Xinjiang selected through the random sampling procedure, additional households that owned photovoltaic systems were purposively selected to develop a profile of photovoltaic system owners. Therefore, statistical inferences cannot be drawn for Gansu and Xinjiang.

Source: China Market Survey 1998. 


\section{APPENDIX B: DATA AND SAMPLING METHODS}

The questionnaire and survey methodology were designed to assess the potential market and to determine the market size of photovoltaic home systems in the Gansu, Inner Mongolia, Qinghai, and Xinjiang Provinces. To achieve these objectives, the survey collected the following information for rural households:

- socioeconomic profile including means of income and wealth;

- current energy usage and expenditure for lighting and batteries, including dry cell, motorcycle, and car batteries;

- household experience with banking, credit unions, or obtaining credit;

- attitudes and preferences toward energy services;

- attitudes and preferences with respect to photovoltaic home systems; and

- knowledge of and access to the photovoltaic market.

As described in the main report, photovoltaic home systems have already been marketed in these four provinces, and many households have already purchased systems. Therefore, through the random sampling process, it was expected that some photovoltaic system homeowners would be selected as part of the random sample. Questions on the type and cost of photovoltaic systems that were owned, methods of purchase, performance of the systems, quality of service, and uses and perceived benefits were included in the questionnaire. These questions were intended to determine the characteristics and profiles of households that have purchased and used photovoltaic systems. Since the number of households with photovoltaic systems selected as part of the random sample was small, it was decided to purposely select households with photovoltaic systems as a supplemental sample. These owners of photovoltaic systems were purposively selected for interview.

\section{TARget Population}

The survey was conducted in four remote provinces in China-Gansu, Inner Mongolia, Qinghai, and Xinjiang. The target population (population frame) within these provinces for the photovoltaic market survey consisted of all rural households living in villages with no access to grid electricity in the counties with an unelectrified rate of more 
than 15 percent. ${ }^{13}$ The main reason that the market survey concentrated on counties with an unelectrified rate of more than 15 percent was that the villages without electricity in such counties have less chance of gaining access to electricity any time soon. Therefore, counties that are closer to complete electrification appear not to have good market potential for photovoltaic systems. Consumers in these counties may opt to wait for grid electricity rather than buy a photovoltaic system. Furthermore, the market size of photovoltaic systems in counties with an unelectrified rate of more than 15 percent is small because it consists of fewer unelectrified households. Of all the four selected provinces, the total number of rural households living in unelectrified villages in the counties with an unelectrified rate of more than 15 percent is estimated to be 1.37 million households. Tables B-1 and B-2 provide a breakdown of the total number of rural households and unelectrified rural households in counties with unelectrified rates of less than and more than 15 percent.

Table B-1: Rural Households and Unelectrified Households

\begin{tabular}{|c|c|c|c|c|c|}
\hline & Gansu & $\begin{array}{c}\text { Inner } \\
\text { Mongolia }\end{array}$ & Xinjiang & Qinghai & Total \\
\hline $\begin{array}{l}\text { Total number of rural households } \\
\text { Number of rural households in: }\end{array}$ & $4,169,218$ & $2,753,990$ & $2,248,512$ & 493,414 & $9,665,134$ \\
\hline $\begin{array}{l}\text { County with }<15 \% \\
\text { unelectrified rate }\end{array}$ & $2,301,491$ & $1,963,192$ & 504,265 & 318,916 & $5,087,864$ \\
\hline $\begin{array}{l}\text { County with }>15 \% \\
\text { unelectrified rate }\end{array}$ & $1,867,727$ & 790,798 & $1,744,247$ & 174,498 & $4,577,270$ \\
\hline $\begin{array}{l}\text { Total number of unelectrified } \\
\text { households } \\
\text { Number of unelectrified } \\
\text { households in: }\end{array}$ & 693,542 & 383,367 & 459,956 & 104,052 & $1,640,917$ \\
\hline $\begin{array}{l}\text { County with }<15 \% \\
\text { unelectrified rate }\end{array}$ & 121,637 & 87,011 & 43,735 & 19,348 & 271,731 \\
\hline $\begin{array}{l}\text { County with }>15 \% \\
\text { unelectrified rate }\end{array}$ & 571,905 & 296,356 & 416,221 & 84,704 & $1,369,186$ \\
\hline
\end{tabular}

13 The 15 percent cutoff point was arbitrarily chosen based on the average 17 percent unelectrified rate in the combined four provinces. 
Table B-2: Targeted Households in Villages without Grid Electricity in Four Selected Provinces

\begin{tabular}{|c|c|c|c|c|c|}
\hline & Gansu & $\begin{array}{c}\text { Inner } \\
\text { Mongolia }\end{array}$ & Xinjiang & Qinghai & $\begin{array}{l}\text { All four } \\
\text { provinces }\end{array}$ \\
\hline Total number of rural households & $1,867,727$ & 790,798 & $1,744,247$ & $1,74,498$ & $4,577,270$ \\
\hline \multicolumn{6}{|l|}{$\begin{array}{l}\text { Number of unelectrified rural } \\
\text { households in: }\end{array}$} \\
\hline 8 surveyed counties & 179,988 & 77,850 & 42,096 & 35,121 & 334,477 \\
\hline (Unelectrified rate) & $(30.92 \%)$ & $(34.47 \%)$ & $(23.04 \%)$ & $(46.51 \%)$ & $(31.43 \%)$ \\
\hline Other counties & 391,917 & 218,506 & 374,125 & 49,583 & $1,034,709$ \\
\hline (Unelectrified rate) & $(30.48 \%)$ & $(38.67 \%)$ & $(23.96 \%)$ & $(50.09 \%)$ & $(29.45 \%)$ \\
\hline $\begin{array}{l}\text { Total number of unelectrified rural } \\
\text { households }\end{array}$ & 571,905 & 296,356 & 416,221 & 84,704 & $1,369,186$ \\
\hline (Unelectrified rate) & $(30.62 \%)$ & $(37.48 \%)$ & $(23.86 \%)$ & $(48.54 \%)$ & $(29.91 \%)$ \\
\hline
\end{tabular}

Note: This tables include all counties with an unelectrified rate of more than 15 percent.

Source: CRED 1998.

\section{SAMPLE SiZE AND DESIGN}

The photovoltaic market survey in the rural areas in Gansu, Inner Mongolia, Qinghai, and Xinjiang Provinces was conducted using a multistage random sampling design. In the survey, questionnaires were used to gauge the market potential for photovoltaic home systems among rural households that have no access to grid electricity. The survey was conducted between August and September 1998. Because of some logistical problems, however, the field survey (of 90 households) in Abagaqi County, Inner Mongolia, was conducted in April 1999. A total of 2,886 households were interviewed. 
Table B-3: Households in Villages without Grid Electricity in Sampled Counties and All Other Counties

\begin{tabular}{lc}
\hline \multicolumn{2}{c}{ Gansu } \\
\hline County sampled & $\begin{array}{c}\text { Number of } \\
\text { households }\end{array}$ \\
\hline Minxian & 44,263 \\
Ningxian & 32,300 \\
Huanxian & 25,400 \\
Zhenyuan & 23,200 \\
Xihe & 19,890 \\
Gulang & 13955 \\
Heshui & 12,600 \\
Zhouqu & 8,380 \\
Total (in sampled counties) & 179,988 \\
Other counties & 391,917 \\
\hline Total unelectrified & 571,905 \\
households (all counties & \\
>15\% unelectrified rate) & \\
\hline Source: China Market Survey 1998.
\end{tabular}

\begin{tabular}{lc}
\hline \multicolumn{2}{c}{ Inner Mongolia } \\
\hline County sampled & $\begin{array}{c}\text { Number of } \\
\text { households }\end{array}$ \\
\hline Shangdu & 19,600 \\
Liangcheng & 16,000 \\
Sizhiwang & 12,900 \\
Xiwuzhumuqing & 9,850 \\
Etuokeqian & 7,400 \\
Dongwuzhumuqing & 5,500 \\
Xingbaerhuzhuo & 4,000 \\
Abaga & 2,600 \\
Total (in sampled counties) & 77,850 \\
Other counties & 218,506 \\
\hline Total unelectrified households & 296,356 \\
(all counties $>15 \%$ & \\
unelectrified rate) & \\
\hline
\end{tabular}




\begin{tabular}{lc}
\hline \multicolumn{2}{c}{ Qinghai } \\
\hline County sampled & $\begin{array}{c}\text { Number of } \\
\text { households }\end{array}$ \\
\hline Nangqian & 8,319 \\
Gonghe & 6,488 \\
Chengduo & 4,667 \\
Menyuan & 3,493 \\
Zhiduo & 3,151 \\
Dulan & 2,906 \\
Maqin & 2,598 \\
Dari & 3,499 \\
Total (in sampled county) & 35,121 \\
Other counties & 49,583 \\
\hline Total unelectrified & 84,704 \\
households (all counties & \\
>15\% unelectrified rate) &
\end{tabular}

\begin{tabular}{cc}
\hline & Xinjiang \\
\hline County sampled & $\begin{array}{c}\text { Number of } \\
\text { households }\end{array}$ \\
\hline Jiashi & 11,303 \\
Akesu City & 8,358 \\
Habahe & 5,932 \\
Cabucaer & 4,740 \\
Changji City & 3,881 \\
Bole City & 3,318 \\
Keping & 2,544 \\
Yuming & 2,020 \\
Total (in sampled counties) & 42,096 \\
Other counties & 374,125 \\
\hline Total unelectrified households & 416,221 \\
(all counties $>15 \%$ & \\
unelectrified rate) & \\
\hline
\end{tabular}

Note: This table includes counties with an unelectrified rate of more than 15 percent.

Source: CRED 1998.

A three-stage sample selection process was employed for the market survey. The first stage of the sample involved taking a stratified random sampling selection of 8 counties with an unelectrified rate of more than 15 percent from each of the four provinces. The eight counties of each province were systematically selected from each stratum of counties that was compiled in order from the highest to the lowest population in unelectrified rural areas. Only counties with an unelectrified rate of more than 15 percent were included in the population frame. The cutoff point at the unelectrified rate of 15 percent was arbitrarily chosen to establish a pool of counties with many households without electricity. As a result, the total 48 counties that were sampled in the first stage have more than 15 percent unelectrified rate. Tables B-3 and B-4 list the counties that were sampled, including the total number of unelectrified households in the county and the province, as well as the number of counties, villages, and unelectrified households that were sampled.

The second stage of the sampling process involved selecting villages at random from the sampled county in the first stage. A list of all unelectrified villages in each selected county was compiled and used as the sampling frame for selecting the villages. Six villages were randomly selected from each selected county. In this stage, 192 unelectrified villages from all four provinces (or 48 unelectrified villages for each province) were selected. Because of the remoteness and harshness of terrain in some counties, the survey team was given some flexibility in selecting villages. For example, in some cases a village in the sample could not be located, had moved to the new location, or was not accessible by truck, boat, horse, yak, or on foot in a reasonable amount of 
time. In such a case, the survey team was allowed to substitute that village with another similar village in the same township. ${ }^{14}$

In the final stage of the sampling procedure, 15 households were randomly selected using the random walk technique. ${ }^{15}$ The main reason for using this technique was that not all villages maintain lists of households, and in many instances lists of households are incomplete or obsolete.

\section{Table B-4: Sample Selection for Photovoltaic Market Survey in Four Selected Provinces in China}

\begin{tabular}{lcccc}
\hline Provinces & $\begin{array}{c}\text { Sample frame: } \\
\text { Counties with } \\
\text { Less than } 85 \\
\text { percent of }\end{array}$ & Counties & Sample selection & Villages (without \\
grid electricity) & Households \\
households without & & & \\
\hline grid electricity & & & 720 \\
Gansu & 27 & 8 & 48 & 724 \\
Qinner Mongolia & 31 & 8 & 48 & 722 \\
Xinjiang & 22 & 8 & 48 & 720 \\
\hline Total & 69 & 8 & 192 & 2,886 \\
\hline
\end{tabular}

Source: CRED 1998.

\section{Purposive Selection of Photovoltaic Households}

Because photovoltaic systems have already been marketed in these four selected provinces and a few rural households have already been using photovoltaic system, the number of photovoltaic households selected at random depended on the actual number of photovoltaic households in the selected counties and villages. Therefore, when the

14 In an extreme circumstances, where there was still no village available in the township to substitute, similar villages in a nearby or adjacent township was substituted.

15 The random walk technique for selecting sample households does not require a list of households. Rather, it is based on the geographical distribution of households in a community or village. The size of the village is generally known. The ratio of the number of households is calculated by dividing the predetermined sample size by the total number of households. For example, in a village of 75 with a sample size of 15 , the ratio would be 6 . The survey enumerator would first select one household at random within the community, and then walk through the entire village taking every sixth household encountered. The result is a random selection of households from the community. 
number of households with photovoltaic systems selected at random was high enough (at least 15 households for each province), the purposive selection of photovoltaic home was not necessary. Through the random sampling process, 116 household photovoltaic system owners were selected at random for interview (see Table B-4). When the number of households with photovoltaic systems selected at random was not high enough (less than 15 households for each province), however, the purposive selection of homes with photovoltaic systems in the province was necessary. Twenty-seven photovoltaic household owners were purposively selected for interview. The main objective of purposive selection was to ensure that there were at least 15 households with photovoltaic systems for each province in order to obtain the descriptive characteristics of such households in the provinces, even though they did not show up in the random sample. Although the purposive selection does not permit us to make any statistical interpretation, it shed some light on some salient characteristics and profiles of owners and users of photovoltaic systems. Table B-5 provides details on the number of sample and purposive photovoltaic home by province.

Table B-5: Sample Size Broken Down by Random and Purposive Selection of Households

\begin{tabular}{|c|c|c|c|c|}
\hline \multirow[b]{2}{*}{ Provinces } & \multicolumn{3}{|c|}{ Random selection of households } & \multirow{2}{*}{$\begin{array}{c}\text { Purposive } \\
\text { selection of } \\
\text { Households with } \\
\text { PV systems }\end{array}$} \\
\hline & $\begin{array}{l}\text { with } P V \\
\text { systems }\end{array}$ & $\begin{array}{c}\text { With other } \\
\text { energy }\end{array}$ & All sampled & \\
\hline Gansu & 1 & 719 & 720 & $15^{*}$ \\
\hline Inner Mongolia & 15 & 707 & 724 & .. \\
\hline Qinghai & 96 & 626 & 722 & .. \\
\hline Xinjiang & 4 & 716 & 720 & $12^{*}$ \\
\hline Total & 116 & 2,768 & 2,886 & 27 \\
\hline
\end{tabular}

* Field interview was conducted in January 1999.

.. Negligible.

Source: CRED 1998.

\section{QUESTIONNAIRE AND CONDUCT OF THE SURVEY}

The questionnaire was developed jointly by the World Bank and Center for Renewable Energy Development (CRED) in China. After initial drafts, adjustments and additions were made to the sections on income and expenditure, energy consumption, expenditure for lighting, and awareness and willingness to purchase renewable energy devices. The questionnaire was pretested during the summer of 1998. A section concerning the use of hybrid systems was also added to the questionnaire. The final questionnaire was revised based on lessons learned from the pretests conducted in Qinghai Province in July 1998 and a focus group study conducted by CRED staff in Inner 
Mongolia in May 1998. Revision of the questionnaire also benefited directly from the input of the rural survey teams in Qinghai Province and the head of the rural survey team from the seven sampled counties in Qinghai Province, who participated in the questionnaire training. The pretest was conducted in two selected villages in Zeku County and Menyeun County, Qinghai Province.

Based on the field implementation arranged by CRED and the Rural Electric Power Bureau, the field surveys in each county were conducted by the county rural survey team. A total of 32 survey teams at the county level were organized to implement the field survey, and each team conducted approximately 90 interviews in the sampled unelectrified villages. Four coordinating offices at the provincial level were selected to help organize survey teams at the county level, as well as to provide technical and logistical support to the survey teams. In Qinghai, the Statistical Office of the province was responsible for helping survey teams of each county in the province to organize the field survey teams, provide backup support (including technical logistical aspects of the survey), and deliver the results of the survey.

\section{Data Processing}

Completed survey forms were sent to CRED in Beijing, and a subcontractor in Beijing performed the data entry. Once the data entry was completed, CRED staff took two additional steps for checking the accuracy of data entry. These additional steps included randomly reviewing the complete survey form and checking all records and variables in the data set against the original survey form. ${ }^{16}$ The final data editing and preparation for data analysis were performed and completed in Washington, D.C.

\section{Data Weighting Procedures}

As indicated, the sampling method was not based on a self-weighting procedure. In reality, however, the number of counties in each province, the number of villages in each county, and the number of households in the selected village were not the same. As a result of an unequal number of elements in the strata and clusters in each sampling stage, the data were weighted in accordance with the actual population in each sampling stage. The weighting procedures consisted of three steps. The first step involved the calculation of a weighting adjustment for counties to correct for their assumption of selecting 15 households per village and 6 villages per county. The second step was to calculate the weighting adjustment for provinces to correct for the assumption of collecting 90 households per county and 8 counties per province. Tables B-1 and B- 2 show the calculation procedures for the county and provincial weight adjustments. The final step involves a calculation to combine the two weights and adjust for the total population covered in the sampling plan (see Table B-3).

16 Approximately 50 percent of survey forms were randomly selected for review. 


\section{Table B-6: Weight Adjustment for County}

\begin{tabular}{lcc}
\hline Ratio in reality & Assumed ratio & First weight \\
\hline $\begin{array}{l}\text { Total number of households in the sampled villages divided } \\
\text { by total number of households in all } 6 \text { sampled villages of } \\
\text { the county }\end{array}$ & $15 / 90$ & $\begin{array}{c}\text { Assumed ratio/ } \\
\text { ratio in reality }\end{array}$ \\
\cline { 1 - 1 } Source: China Market Survey 1998. & &
\end{tabular}

\section{Table B-7: Weight Adjustment for Province}

\begin{tabular}{lcc}
\hline Ratio in reality & Assumed ratio & Second weight \\
\hline $\begin{array}{l}\text { Total number of households in all } 6 \text { sampled } \\
\text { villages of the county divided by the total number } \\
\text { of households in all } 8 \text { counties of the provinces } \\
\text { (48 villages in the province) }\end{array}$ & $\begin{array}{c}\text { Assumed ratio/ratio in } \\
\text { reality }\end{array}$ \\
\hline * The denominator for Inner Mongolia is 724, and the denominator for Xinjiang is 722 (that is, the exact \\
number of households sampled). \\
Source: China Market Survey 1998.
\end{tabular}

Table B-8: Final Weight Adjustment Procedure

\begin{tabular}{ll}
\hline Province & \multicolumn{1}{c}{ Calculation procedures } \\
\hline Gansu & (First Weight x Second weight) x (571,905/720) \\
Inner Mongolia & (First Weight x Second weight) x 296,356/724) \\
Xinjiang & (First Weight x Second weight) x 416,221/722) \\
Qinghai & (First Weight x Second weight) x 84,704/720) \\
\hline \multicolumn{2}{l}{ Source: China Market Survey 1998. }
\end{tabular}

\section{ESTIMATION OF STANDARD ERRORS AND CONFIDENCE INTERVAL}

As indicated, the data used in this report were based on a complex sample design. Therefore, variance and standard errors must be computed in accordance with the complexity of the sample designs. In this report, the calculation of standard errors of the selected mean are primarily based on separating sources of variation, and then calculating the associated variance of the data collected at different stages of sampling. This has been completed for such variables as the average household monthly income, total value of assets owned, and the average monthly expenditure for lighting fuels and other energy. Relying on "analysis of variance" of the mean techniques, the total components of variance are comprised of (a) variation between counties, (b) variation between villages 
within counties, and (c) variation within villages. For example, the estimated variance and standard errors of the estimated household monthly income for Gansu Province is demonstrated in Tables B-9 and B-10. ${ }^{17}$

Table B-9: Estimated Variance and Standard Errors of Household Monthly Income in Gansu

\begin{tabular}{lcccc}
\hline Sources of variations & Sum of squares & $\begin{array}{c}\text { Degrees of } \\
\text { freedom }\end{array}$ & Mean square & $\begin{array}{c}\text { Standard } \\
\text { error of mean }\end{array}$ \\
\hline Between counties & $8,766,750$ & $(8-1)=7$ & 125,239 & 422 \\
Between villages within & $15,248,244$ & $8(6-1)=40$ & 381,206 & 97 \\
counties & $10,058,479$ & $48(15-1)=672$ & 14,967 & 4.7 \\
Within villages & 25,306723 & $(720-1)=719$ & 35,197 & 6.9 \\
\hline Total & & & & \\
\hline
\end{tabular}

Source: China Market Survey 1998.

As a consequence, the confidence interval for household monthly income in Gansu can be calculated as follows:

$$
\begin{aligned}
& \text { Average monthly income }+/-\left(\mathrm{t}_{\mathrm{a} / 2=.05,719} * \mathrm{SE}\right) \\
& 208.46+/-(1.96 * 6.9966)=208.46+/-13.71
\end{aligned}
$$

Based on the analysis of the components of variance described above, Table B-10 provides a summary of standard errors and confidence intervals for average household monthly income, the total value of assets owned, and the total monthly expenditure for lighting fuels and other noncooking energy by province.

Table B-10: Summary of Standard Error and Confidence Interval

\begin{tabular}{lccc}
\hline & $\begin{array}{c}\text { Monthly income } \\
\text { (yuan) }\end{array}$ & Standard error (SE) & $\begin{array}{c}\text { Confidence } \\
\text { interval } \\
\left(t_{. a / 2=.05,719} * S E\right)\end{array}$ \\
\hline Gansu & 208.46 & 6.9966 & $+/-13.71$ \\
Inner Mongolia & $1,372.39$ & 70.1568 & $+/-137.51$ \\
Xinjiang & 712.73 & 119.8234 & $+/-234.85$ \\
Qinghai & 597.66 & 17.1169 & $+/-33.5491$ \\
\hline \multicolumn{4}{c}{ Total value of assets } \\
owned & Standard error $($ SE $)$ & Confidence \\
& & & interval \\
\hline
\end{tabular}

\footnotetext{
17 Leslie, Kish, Survey Sampling (John Wiley \& Sons, Inc., New York, 1965), p. 173.
} 


\begin{tabular}{|c|c|c|c|}
\hline & & & $\left(t_{. a / 2=.05,719} * S E\right)$ \\
\hline Gansu & $5,311.80$ & 172.2439 & $+/-337.60$ \\
\hline Inner Mongolia & $51,910.12$ & 2611.5877 & $+/-5,118.71$ \\
\hline Xinjiang & $18,505.64$ & 2290.1155 & $+/-4,488.63$ \\
\hline \multirow[t]{2}{*}{ Qinghai } & $53,210.77$ & 1680.1724 & $+/-3,293.1379$ \\
\hline & $\begin{array}{l}\text { Expenditure of } \\
\text { lighting fuels }\end{array}$ & Standard error (SE) & $\begin{array}{c}\text { Confidence } \\
\text { interval } \\
\left(t_{. a / 2=.05,719} * S E\right)\end{array}$ \\
\hline Gansu & 5.66 & 0.1278 & $+/-0.25$ \\
\hline Inner Mongolia & 14.71 & 0.8631 & $+/-1.69$ \\
\hline Xinjiang & 14.65 & 0.5517 & $+/-1.08$ \\
\hline Qinghai & 31.79 & 1.5767 & $+/-3.09$ \\
\hline
\end{tabular}

Source: China Market Survey 1998. 


\section{APPENDIX C: QUESTIONNAIRE}

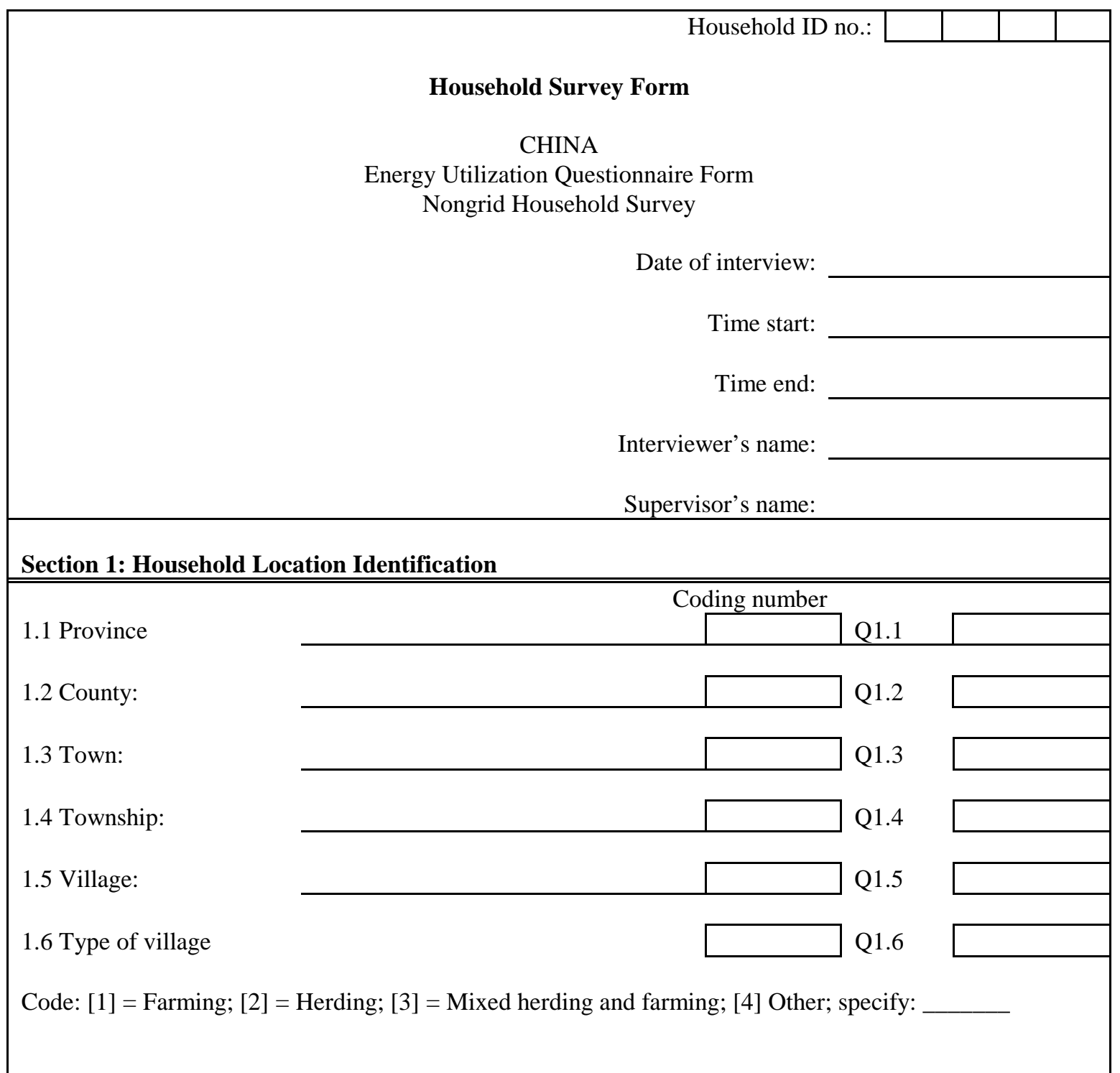

Note: Coding number must be assigned to county, town, township, and village.

$$
\begin{array}{ll}
\text { Coding: } & {[-7]=\text { Do not apply }} \\
& {[-8]=\text { No answer }} \\
& {[-9]=\text { Missing value }}
\end{array}
$$


Section 2. Socioeconomic Information

Name of respondent:

2.1a Sex of the respondent

Code: $[1]=$ Male

$$
[2]=\text { Female }
$$

2.1b Age of respondent:

2.1c Educational level of respondent:

Code: $[0]=$ Illiterate

$$
\begin{aligned}
& {[1]=\text { Primary school }} \\
& {[2]=\text { Junior high school }} \\
& {[3]=\text { Senior high school }} \\
& {[4]=\text { High vocational school }} \\
& {[5]=\text { Collage and university education }} \\
& {[6]=\text { Postgraduate education }}
\end{aligned}
$$

2.1d Respondent's relationship to head of household

Code: $[1]=$ Head of the household

[2] = Head of household's wife or husband

[3] = Daughter

[4] = Son

[5] = Daughter-in-law

[6] = Son-in-law

[7] = Other; specify:

2.2 Sex of the head of household

Code: $[1]=$ Male

[2] = Female

2.3 Age of the head of household: years old

2.4 Age of spouse of head of household years old

2.5 Occupation of the head of household

Code: $[1]=$ Farmer

[2] = Herdsman

[3] = Mixed herding and farming

[4] = Local TVE workers

[5] = Outside TVE workers

[6] = Local manager

[7] = Retired

$[8]=$ Other:

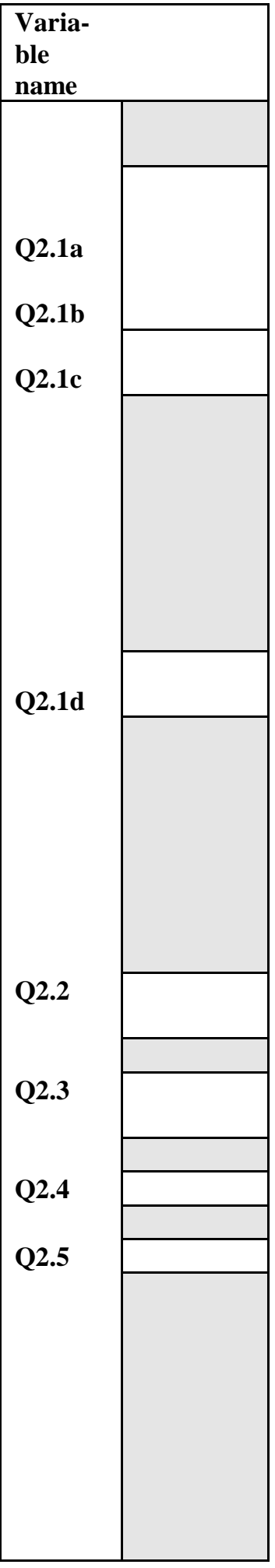


2.6 Educational level of head of household

Code: $[0]=$ Illiterate

[1] = Primary school

[2] = Junior high school

[3] = Senior high school

[4] = High vocational school

[5] = Collage and university education

[6] = Postgraduate education

2.7 How many persons live in your household for most of the year (that is, more than 6 months in a year)?

(Fill in according to age.)

Less than 6 years

$7-18$ years

19-60 years

$2.7 \mathrm{c}$

61 years and over

$2.7 \mathrm{e}$

Total

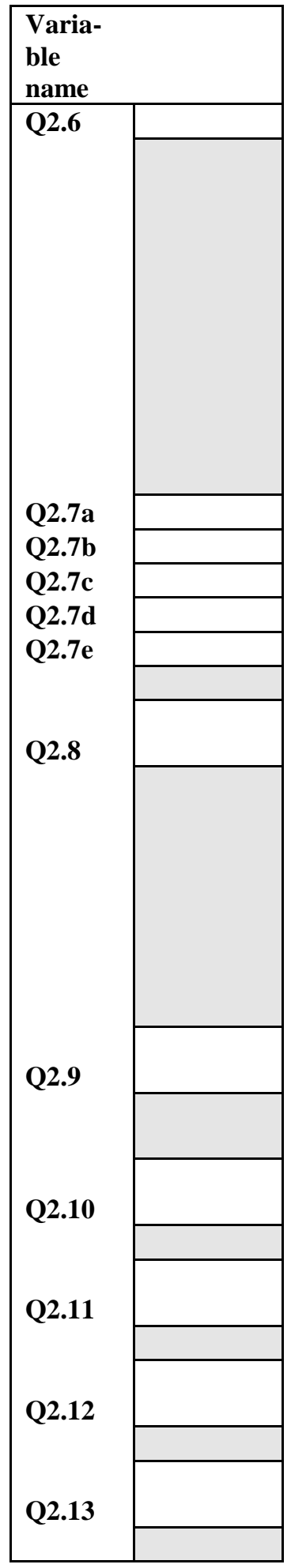

2.9 How many persons in your household earn income?

(Include all types of income earned.)

Information on Responding Household's Dwelling Unit

2.10 How many dwelling units does your household have? units

2.11 What is the size of your permanent home (in square meters)? square meters

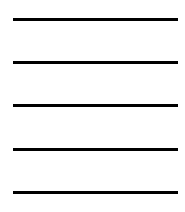

What is the highest educational level of immediate adult family member of the household?

(regardless of where he or she lives)

[2] = Junior high school

Senior high schoo

[5] = Collage and university education

[6] $=$ Postgraduate education

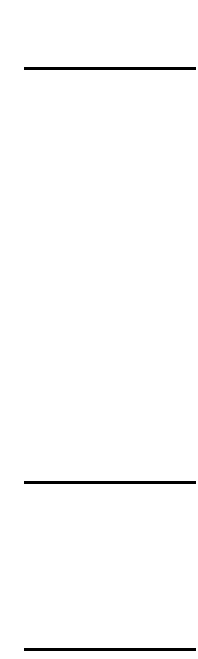

Q 
Section 3. Income from Agricultural Activities, Livestock Holdings, and Livestock

3.1 Total under cultivation $(\mathrm{Mu})$

(Include all land used to cultivate.)

3.2 Total land owned $(\mathrm{Mu})$

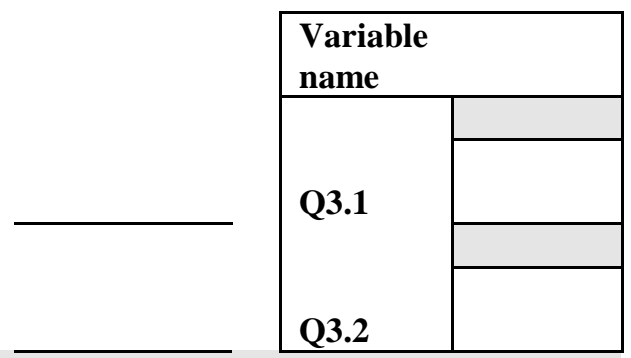

\section{Type of Crops Planted Last Year}

3.3 Grain

$3.4 \quad$ Oil bearing

3.5 Economic or commercial crops

(Enter name of the crop.)

3.7

(Enter name of the crop.)

3.8

(Enter name of the crop.)

\section{Total Expenditure for Agricultural Activities}

(Include all expenditures, such as for fertilizers, herbicides, pesticides, land rental, water pumping

fees, or labor.)

3.9 Land rental fees

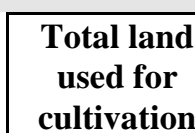

(Mu)
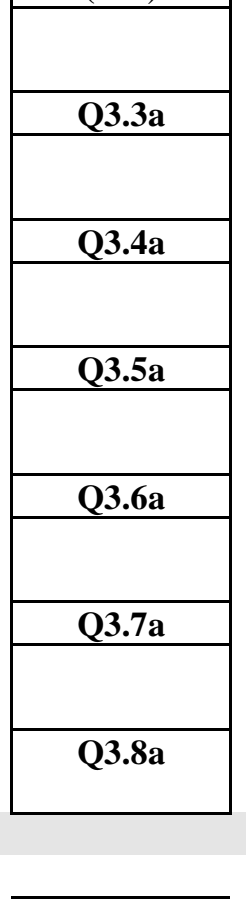

3.10 Fertilizers, herbicides, pesticides

$3.11 \quad$ Seeding

3.12 Irrigation or water user fees

3.13 Labor

\begin{tabular}{|l|l|}
\hline \multicolumn{2}{|l|}{$\begin{array}{l}\text { Variable } \\
\text { name }\end{array}$} \\
\hline & \\
& \\
Q3.1 & \\
& \\
\cline { 2 - 2 } Q3.2 & \\
\hline
\end{tabular}

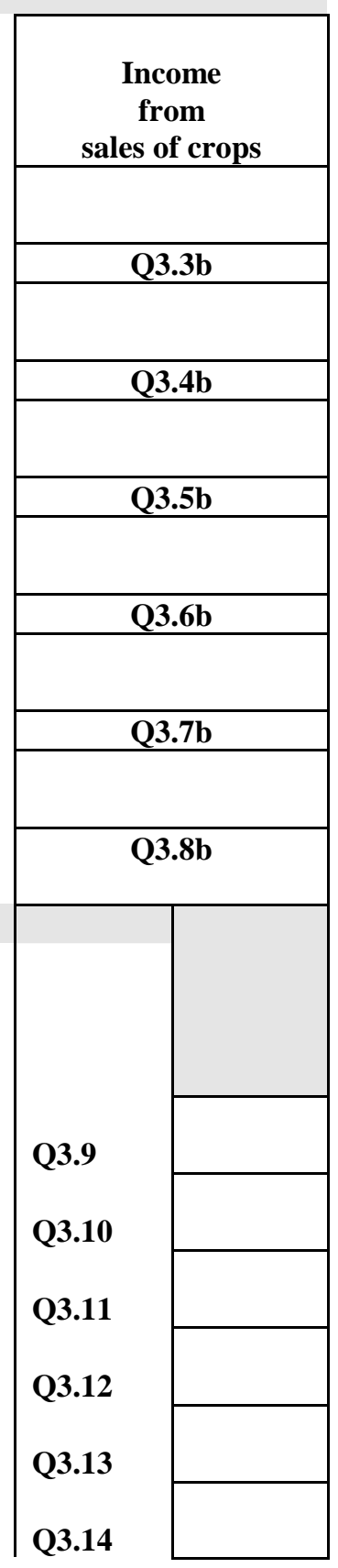


3.14 Other expenditures; specify:

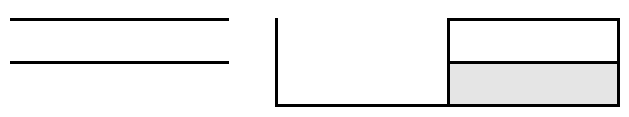


Section 3. (continued)

Total Number of Livestock and Domestic Fowls Currently Owned by the Family, Number Sold Last Year, Sale Price per Animal, and Net Revenue from Each Type of Animal Sold

Total no.

owned

currently

3.15 Sheep

3.16 Goats

$3.17 \quad$ Yaks

3.18 Cattle

$3.19 \quad$ Horses

$3.20 \quad$ Pigs

$3.21 \quad$ Domestic fowls

3.22 Other animals; specify:

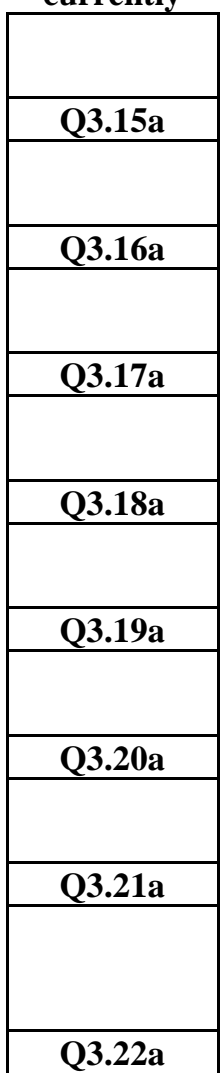

Total no.

sold

last year

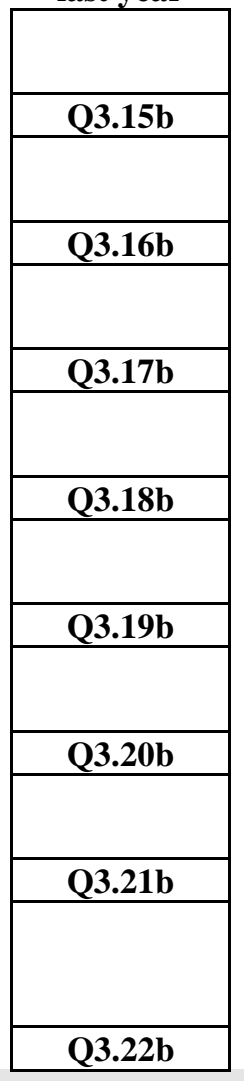

Sale price per animal sold

last year (yuan)

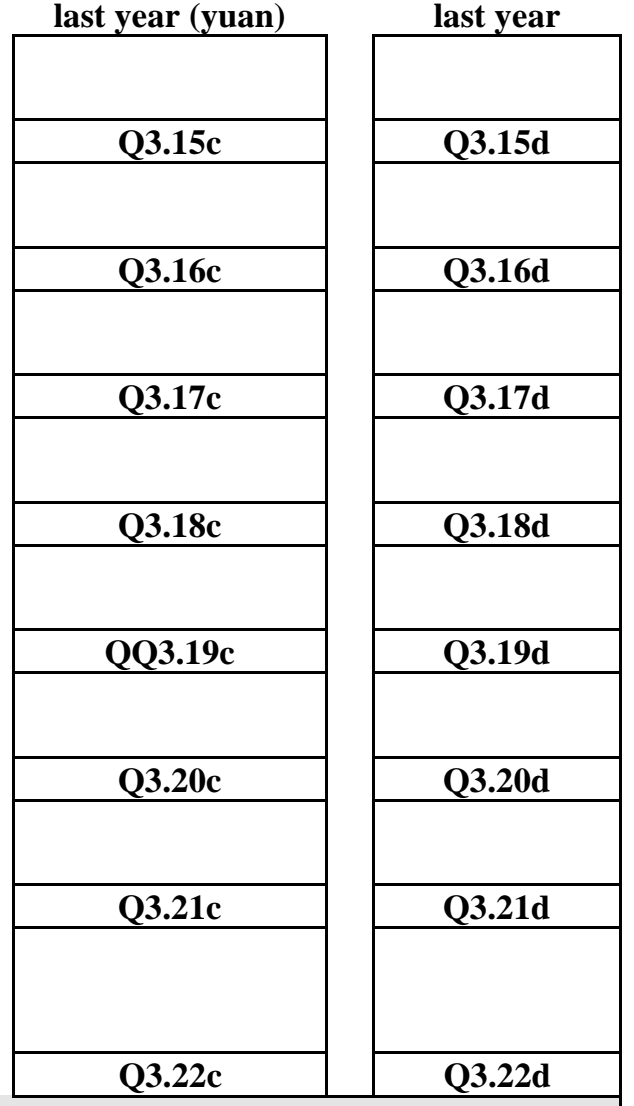

Total Expenditure for Livestock

(Include all expenditures related to livestock activities, such as expenditures for vaccinations, the purchase of baby animals, land rental, and fodder.)

3.23 Baby animals, husbandry

$3.24 \quad$ Feedstocks and fodder

3.25 Labor

$3.26 \quad$ Vaccinations and medicine

3.27 Other expenditures; specify:

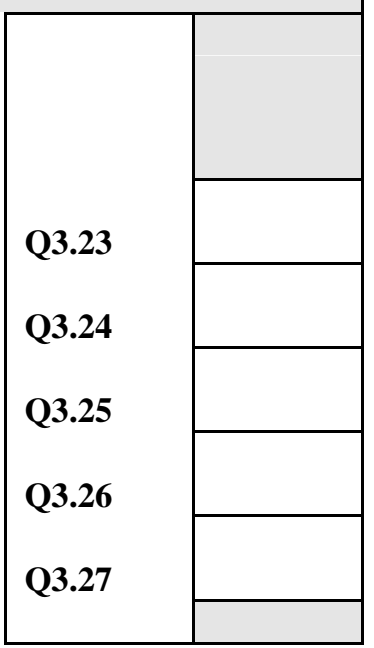




\section{Section 4. Household Cash Income and}

\section{Expenditures}

Total income last year (whole year)

4.1a Cash income from agriculture

4.1b Cash income from sales of livestock and domestic fowls, animal husbandry activities, and related byproducts

4.1c Income from fruit trees, tree planting etc.

4.1d Wages and bonuses

4.1e Government subsidies or remittances from relatives

4.1f Income from cultivation of medicinal and wild plants

4.1g Income from hunting

4.1h Other income; specify:

4.1 Total household income last year

\section{Total Household Expenditures}

Total expenditures last year

4.2a Expenditures for agriculture

4.2b Expenditures for animal husbandry and other expenditures related to livestock and domestic fowls

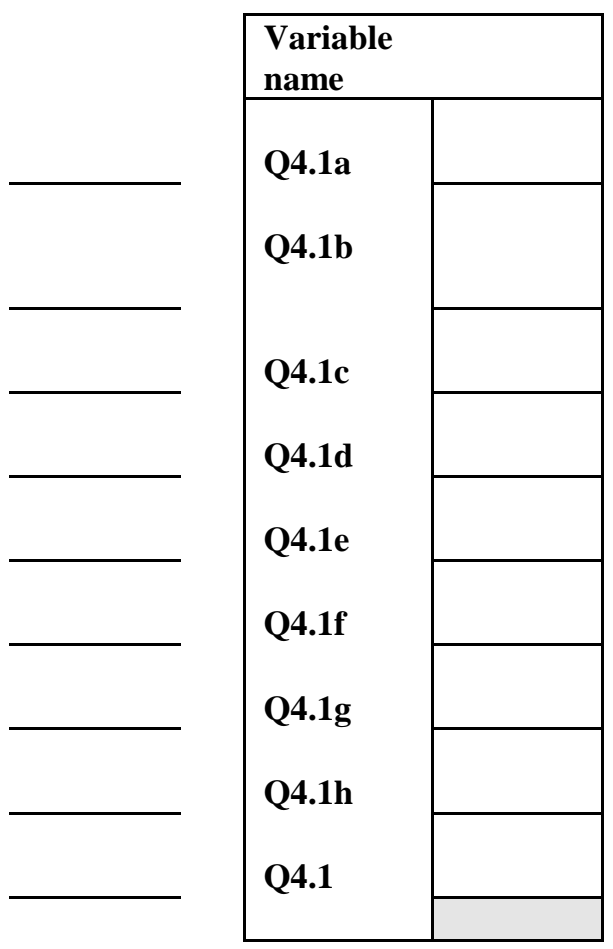

4.2c Expenditures related to fruit trees and tree planting

4.2d Daily living

4.2e Expenditures for coal

4.2f Medical

$4.2 \mathrm{~g} \quad$ Taxes

4.2h Other expenditures

4.2 Total household expenditures

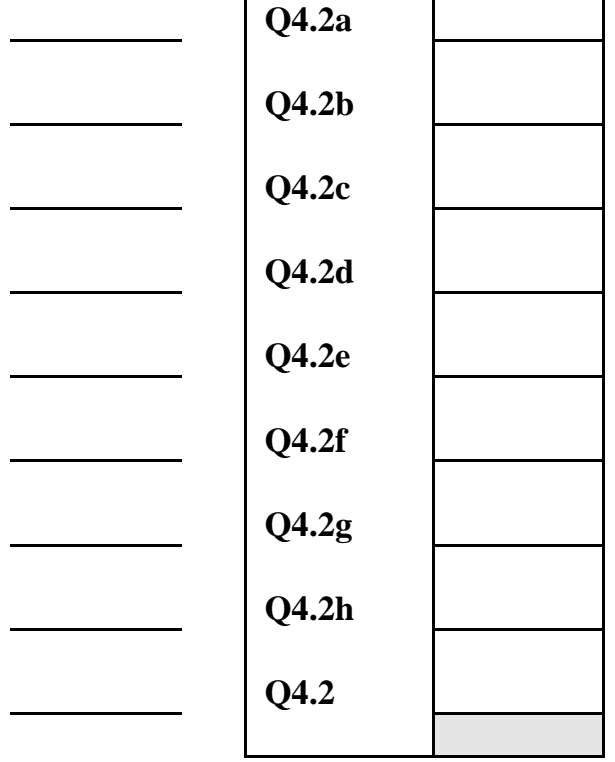




\section{Section 5. Purchasing History and Plans}

\section{History}

How many durable goods does your household own, and how did you buy any of the following in the past?

Code: $\quad[1]=$ Have, but purchased with cash in full payment

[2] = Have, but purchased by installment

[3] = Have, but purchased by barter

[4] = Have, but purchased jointly with neighbor or relative

\begin{tabular}{|l|l|}
\hline $\begin{array}{l}\text { Variable } \\
\text { name }\end{array}$ & $\begin{array}{l}\text { Number } \\
\text { owned }\end{array}$ \\
\hline
\end{tabular}

\section{Agricultural machinery:}

$\begin{array}{lll}5.1 & \text { Seeders } & \text { Q15.1a } \\ 5.2 & \text { Harvesters } & \text { Q15.2a }\end{array}$

\section{Herding machinery:}

5.3 Sheep clippers

Q15.3a

$$
5.4
$$

Milkers

Q15.4a

\section{Household appliances:}

5.5

Radio-tape cassettes

Q15.5a

5.6

Black-and-white televisions

Q15.6a.

\section{7}

Color televisions

Q15.7a

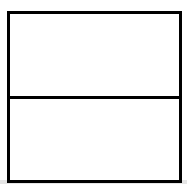

\begin{tabular}{|l|l|}
\hline $\begin{array}{l}\text { Variable } \\
\text { name }\end{array}$ & $\begin{array}{c}\text { Type of } \\
\text { pur- } \\
\text { chase }\end{array}$ \\
\hline & \\
& \\
Q5.1b & \\
\hline & \\
\hline
\end{tabular}

Q5.3b

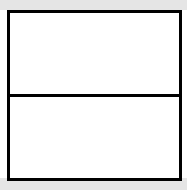

Q5.4b

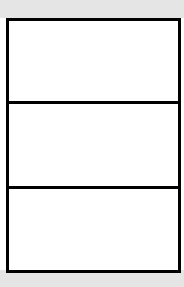

\section{Vehicles:}

$5.8 \quad$ Cars

Q15.8a

5.9

Tractors

Q15.9a

5.10

Motorcycles

Q15.10a

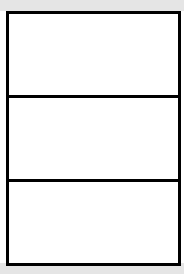

Q5.5b

Q5.6b

Q5.7b

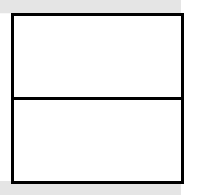

\section{$5.11 \quad$ Others:}

Q15.11a

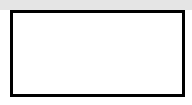

Q5.11b

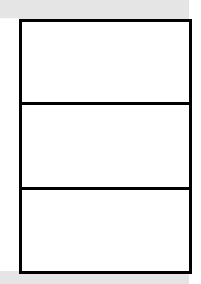

Q5.8b

Q5.9b

Q5.10b

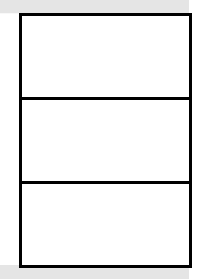


Section 5. Purchasing History and Plans

\section{Plan}

How do you plan to buy any of the following durable goods?

Code: $[1]=$ Plan to purchase by cash

[2] = Plan to purchase by installment

[3] = Plan to purchase barter

[4] = Plan to purchase jointly with neighbor or relative

[5] = Do not have plan to purchase by any means

Agricultural machinery:

$5.12 \quad$ Seeders

$5.13 \quad$ Harvesters

Herding machinery:

$5.14 \quad$ Sheep clippers

$5.15 \quad$ Milkers

Household appliances:

5.16 Radio-tape cassettes

5.17 Black-and-white televisions

5.18 Color televisions

Vehicles:

5.19 Cars

$5.20 \quad$ Tractors

$5.21 \quad$ Motorcycles

Others:

\begin{tabular}{|l|l|}
\hline \multicolumn{1}{|l|}{$\begin{array}{l}\text { Variable } \\
\text { name }\end{array}$} \\
\hline \\
\\
\\
\end{tabular}




\section{Section 6. Household Credit Standing and History}

6.1 How much savings (in cash) does your household have? yuan

(Include all cash saved either at home or deposited at the bank or credit union.)

6.2 Have your household ever taken any loan?

Code: $[0]=$ No

$\bar{\square}$

(If "No", go to Q7.1.)

6.3 If yes, how much was the loan? yuan

6.4a If yes, in which year did you take current loan?

(Enter year, such as 1995, 1997, etc.)

6.4b If yes, how long was the loan? months

6.5 If yes, what was the interest rate? $\%$ per year

6.6 If yes, how much in loans (yuan) does your household currently have? yuan

(Enter "O" if the loan was paid off or if you do not have any outstanding loan.)

6.7 What was the source of your loan?

Code: $[1]=$ Bank

[2] = Credit union

[3] = Relatives

[4] $=$ Neighbors

[5] = Other; specify:

6.8 What was the purpose of the loan?

Code: $[1]=$ To buy food

[2] = Build, expand, or repair house

[3] $=$ Medical treatment or medicine

[4] = Business

[5] = Buy equipment or appliance

[6] $=$ Fodder

[7] = Family social function, marriage, funeral [8] = Other; specify:

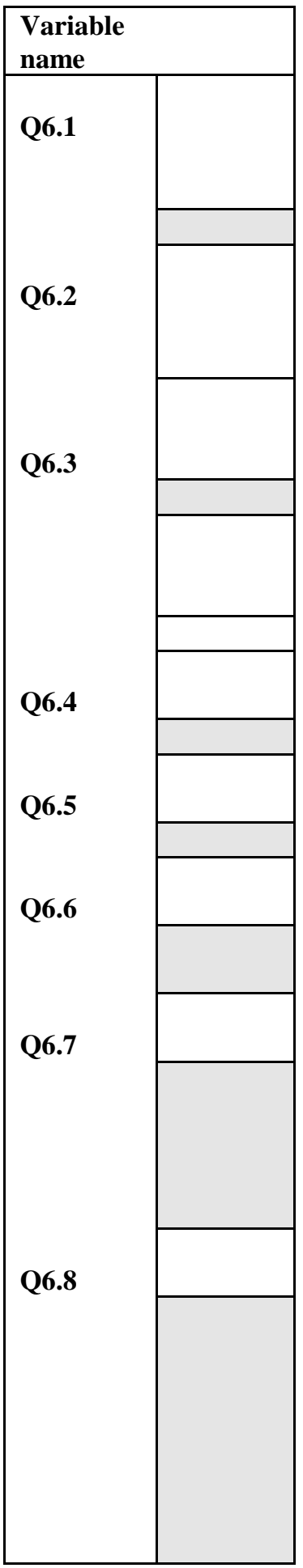




\section{Section 7. Sources of Electricity and Other Energy}

What are your usual sources of energy in the household?

Code: $[0]=$ No

$$
[1]=\text { Yes }
$$

7.1 Dry cell battery

7.2 Butter
No
Yes
No

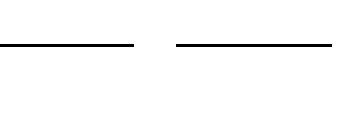

7.3 Candles

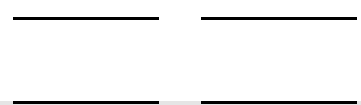

7.4 Kerosene

7.5 Diesel for lighting

7.6 Gasoline for lighting

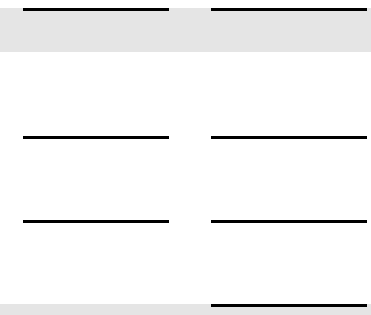

7.7 Car battery

7.8 Small-scale power generator

Electric generator set

7.9 Small wind home system

7.10 PV-wind hybrid system

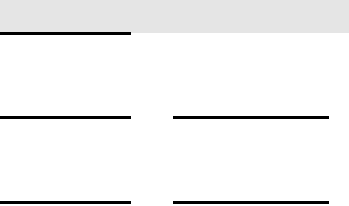

7.11 PV system (electricity from the household's own PV system)

7.12 Firewood

7.13 Charcoal

7.14 Dried animal dung

7.15 Coal and coal briquette

7.16 Biogas

7.17 Other; specify:

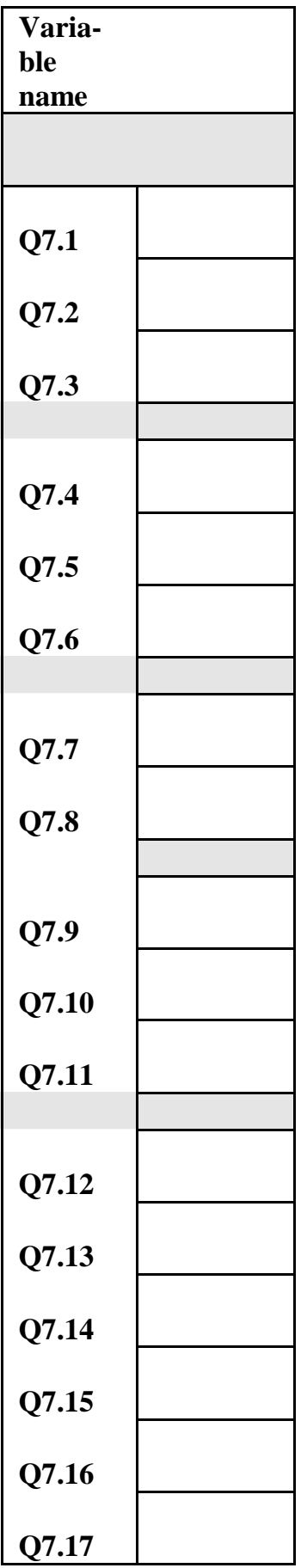


Section 8. Dry Cell Batteries

8.1 During the past 12 months, did your household use dry cell batteries for an application, such as flashlight,

lantern, combined flashlight and lantern, radio, or tape cassette?

Code: $[0]=$ No

$[1]=$ Yes;

(If “No", go to Q9.1.)

8.2 On the average, how many times does your household buy dry cell batteries per year? times per year

8.3 On the average how much does your household spend on dry cell batteries for each purchase? purchase yuan per

8.4 On the average, how much does your household spend on dry cell batteries per month? yuan

8.5 On the average, how many hours per month does your household use electricity from a dry cell battery for productive purposes? hours per month

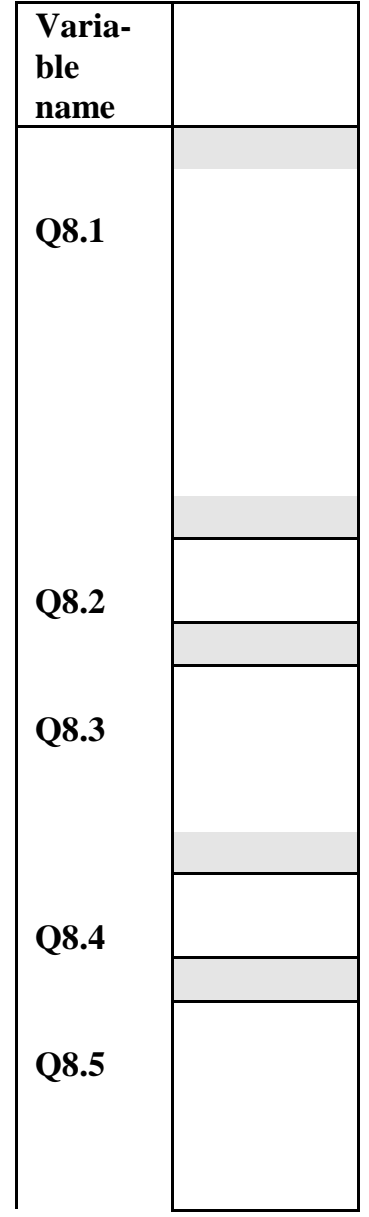




\section{Section 9. Butter for Lighting}

9.1 During the past 12 months how often did your household use butter for lighting?

Code: $[0]=$ Do not use butter for lighting

$$
\begin{aligned}
& \text { (If "Not use butter," go to Q10.1.) } \\
& \text { [1] = Used sometimes } \\
& \text { [2] = Used butter most of the time } \\
& \text { [3] = Always }
\end{aligned}
$$

How many kilograms of butter does your household usually use per month? kilograms

9.3 What is the price or market value of butter per kilogram? yuan per kilogram

9.4 How many hours per month does your household use butter for lighting for productive purposes? hours per month

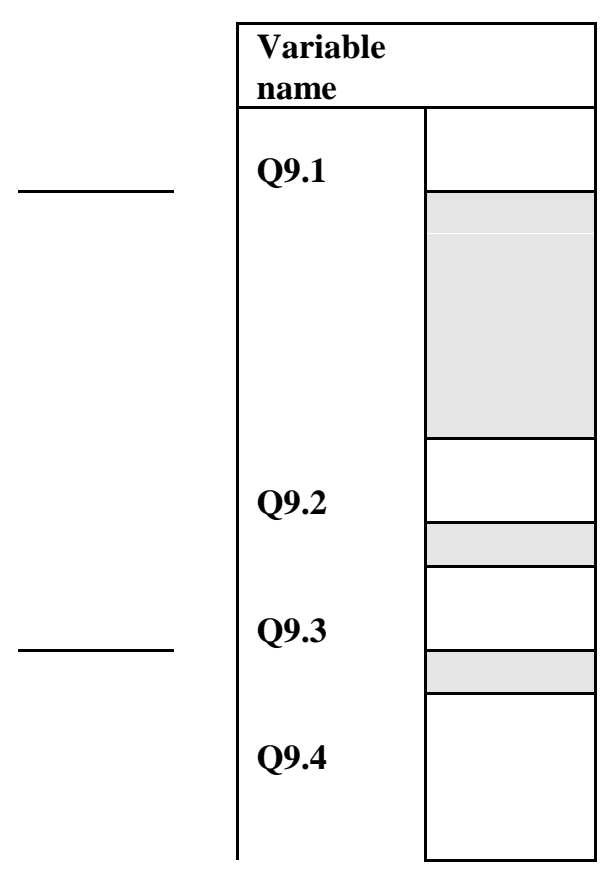




\section{Section 10. Candles}

10.1 During the past 12 months, how often did your household use candles for lighting?

Code: $[0]=$ Do not use candle for lighting

$$
\begin{aligned}
& \text { (If "Not use candles," go to Q11.1.) } \\
& \text { [1] = Used sometimes } \\
& \text { [2] = Used candle most of the time } \\
& \text { [3] = Always }
\end{aligned}
$$

10.2 How many times does your household buy candles per year? times per year

10.3 On the average, how much does your household spend on candles for each purchase? yuan

10.4 On the average, how much does your household spend on candles each month? yuan per month

10.5 In general, how many hours per week does your household use candlelight? hours per week

10.6 On the average, how many hours per month does your household use candles for productive purposes? hours per month

(Enter " 0 " for no use.)

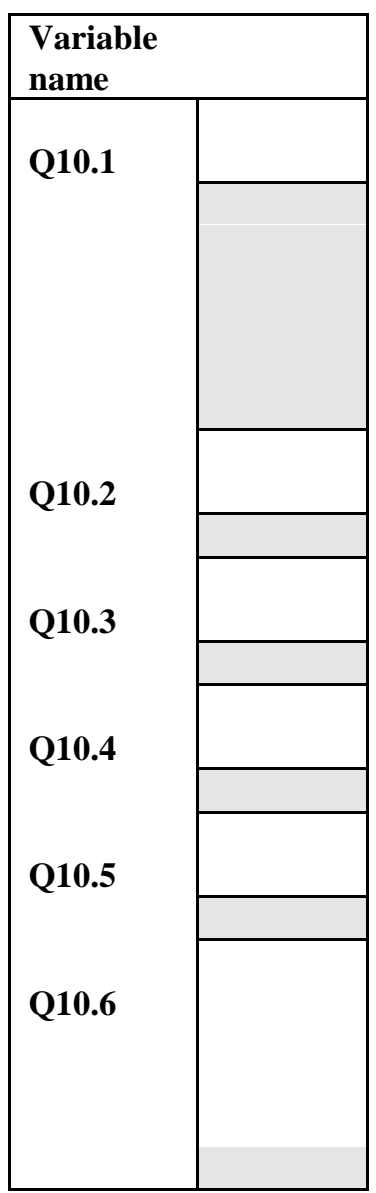




\section{Section 11. Kerosene}

11.1 During the past 12 months, how often did your household use kerosene for lighting?

Code: $[0]=$ No, did not use

$$
\begin{aligned}
& \text { (If "No", go to Q12.1.) } \\
& \text { [1] = Used sometimes } \\
& \text { [2] = Used most of the time } \\
& \text { [3] = Always }
\end{aligned}
$$

11.2 In general, which type of unit and how much of the typical unit of kerosene at what price per unit does your household usually purchase?

11.2a Which type of unit does your household usually use to buy kerosene?

Code: $[1]=$ Liter

$$
[2]=\text { Kilogram }
$$

11.2b How many of the typical units of kerosene does your household usually buy each time?

11.2c What is the price of kerosene per typical unit that your household usually buys? yuan

11.3 Generally, how many times does your household buy kerosene in a year? times per year

11.4 On the average, how much does your household spend on kerosene per month? yuan

11.5 When your household uses kerosene, how many of the typical units are usually used in a month? units per month

11.6 How many of the typical units are used for lighting each month? units per month

(Kerosene may be used for many purposes. Ask for the amount used for lighting only.)

11.7 In general, how many hours per day does your household use kerosene for light? hours per day

11.8 On the average how many hours per month does your household use kerosene for productive purposes? hours per month

(Enter "O" for no use.)

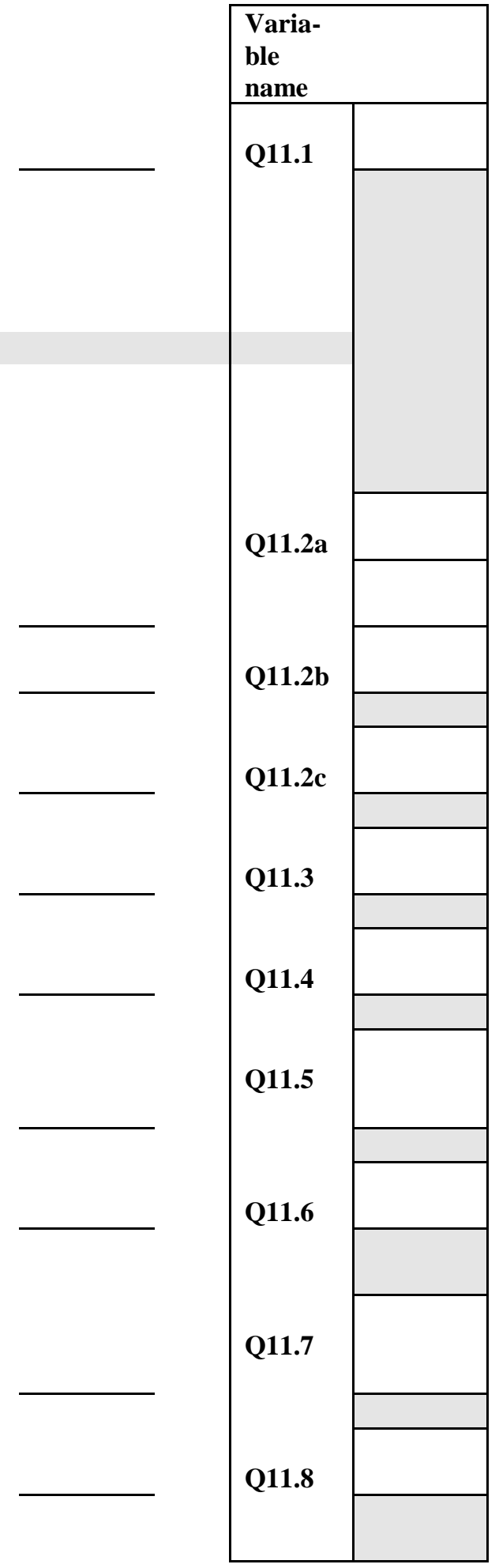




\section{Section 12. Diesel for Lighting}

12.1 During the past 12 months, did your household use any diesel for lighting?

Code: $[0]=$ No, did not use

$$
\begin{aligned}
& \text { (If "No", go to Q13.1.) } \\
& \text { [1] = Used sometimes } \\
& \text { [2] = Used most of the time } \\
& \text { [3] = Always }
\end{aligned}
$$

12.2 In general, which type of unit and how much of the typical unit of diesel and at what price per unit does your household usually purchase?

12.2a Which type of unit does your household usually use to buy diesel?

Code: $[1]=$ Liter;

[2] = Kilogram

12.2b How many of the typical units of diesel does your household usually buy each time?

12.2c What is the price of diesel per typical unit that your household usually buys? yuan

12.3 Generally, how many times does your household buy diesel in a year? times per year

12.4 On the average, how much does your household spend on diesel per month? yuan

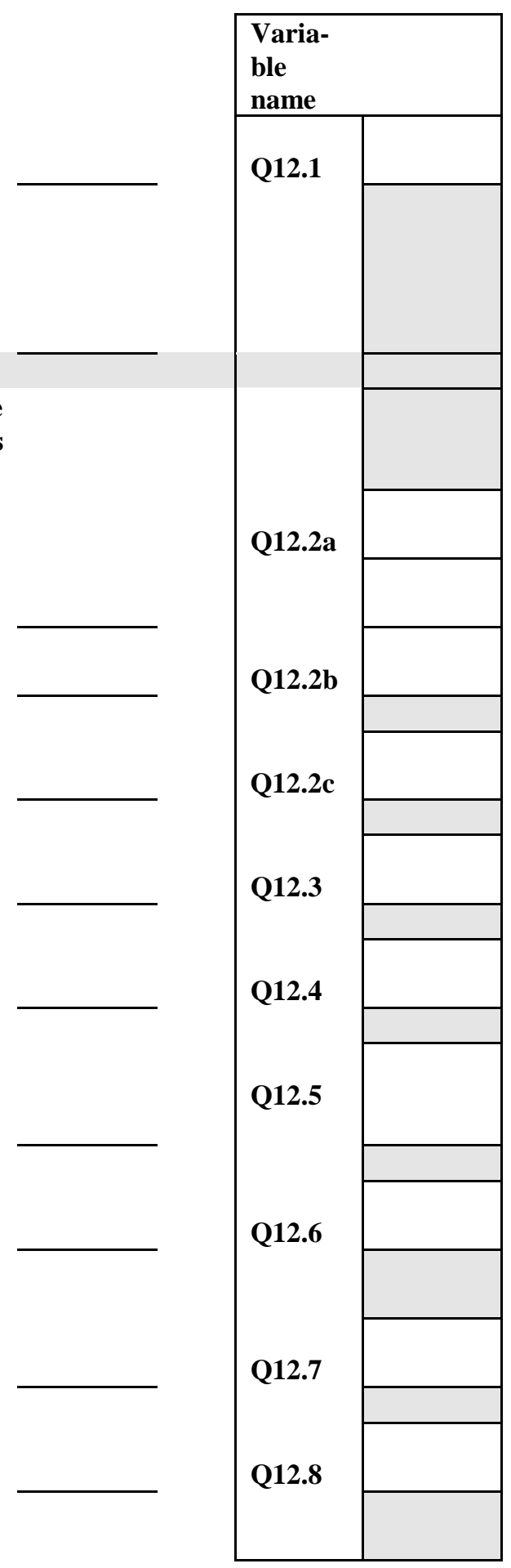

12.5 When your household uses diesel, how many of the typical units are usually used in a month? units per month

12.6 How many of the typical units are used for lighting each month? units per month

(Diesel may be used for many purposes. Ask for the amount used for lighting only.)

12.7 In general, how many hours per day does your household use diesel for light? hours per day

12.8 On the average, how many hours per month does your household use diesel light for productive purposes? hours per month (Enter "0" for no use.) 


\section{Section 13. Gasoline for Specialized Lamps for}

\section{Lighting}

13.1 During the past 12 months, did your household use any gasoline for lighting?

Code: $[0]=$ No, did not use

$$
\begin{aligned}
& \text { (If "No", go to Q14.1.) } \\
& \text { [1] = Used sometimes } \\
& \text { [2] = Used most of the time } \\
& \text { [3] = Always }
\end{aligned}
$$

13.2 In general, which type of unit and how much of the typical unit of gasoline and at what price per unit does your household usually purchase?

13.2a Which type of unit does your household usually use to buy gasoline?

Code: $\quad[1]=$ Liter

$$
\text { [2] = Kilogram }
$$

13.2b How many of the typical unit of gasoline does your household usually buy each time?

13.2c What is the price of gasoline per typical unit? yuan

13.3 Generally, how many times does your household buy gasoline in a year? times per year

13.4 On the average, how much does your household spend on gasoline per month? yuan

13.5 When your household uses gasoline, how many of the typical units are usually used in a month? per month units

13.6 How many of the typical units are used for lighting each month? units per month

(Gasoline may be used for many purposes. Ask for the amount used for pressurized lamp lighting only.)

13.7 In general, how many hours per day does your household use gasoline for light? hours per day
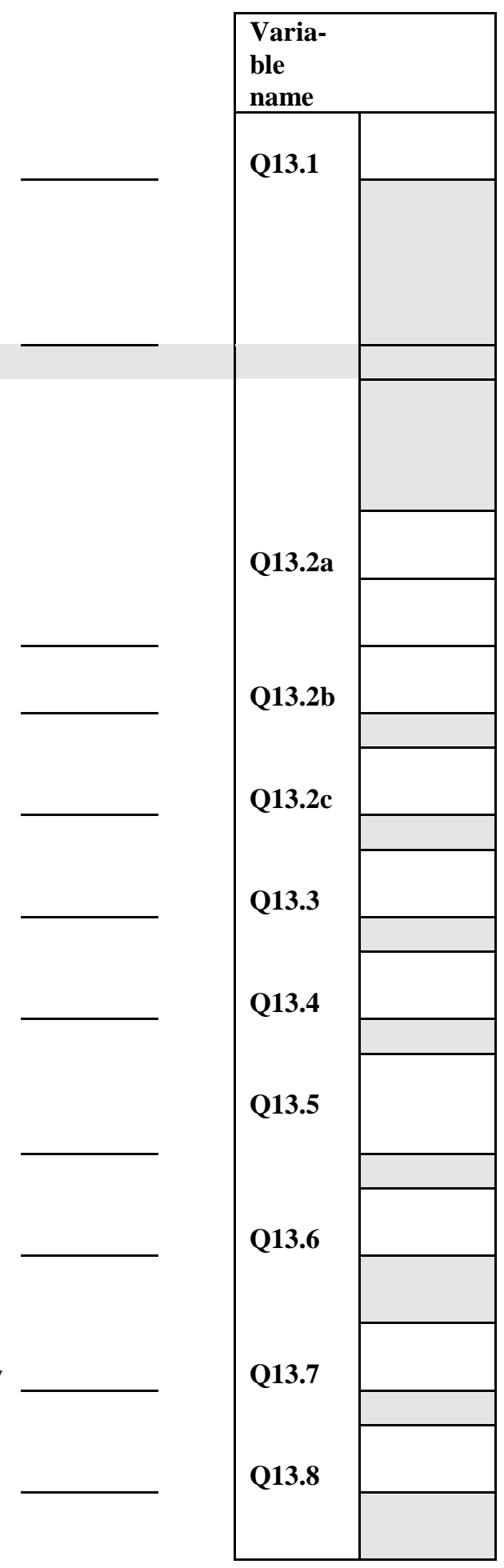

13.8 On the average, how many hours per month does your household use gasoline light for productive purposes? hours per month

(Enter “O” for no use.) 


\section{Section 14. Electricity from Car Batteries}

14.1 During the past 12 months, did your household use a car battery to supply electricity?

$$
\begin{aligned}
& {[0]=\text { No }} \\
& \text { (If "No", go to Q15.1.) } \\
& \text { [1] = Yes }
\end{aligned}
$$

14.2 During the past 30 days did your household use a car battery to supply electricity?

Code: $[0]=$ No, did not use

$[1]=$ Used as supplementary source of electricity [2] = Used as the main source of electricity (If [1] "Used as the supplementary..." OR [2] "Used as the main source...," go to Q14.4.)

14.3 Please give me reasons your household has not used your car battery during the past 30 days.

Code: $[1]=$ Out of order

[2] = Already been electrified

$[3]=$ Recharge is too costly

$[4]=$ No transportation

[5] = Other; specify:

14.4 How many batteries does your household have? batteries

$14.5 \mathrm{a}$ What is the voltage of your first car battery? volts

14.5b What is the ampere-hours of your first car battery? ampere-hours

14.5c How much did the first car battery cost? yuan

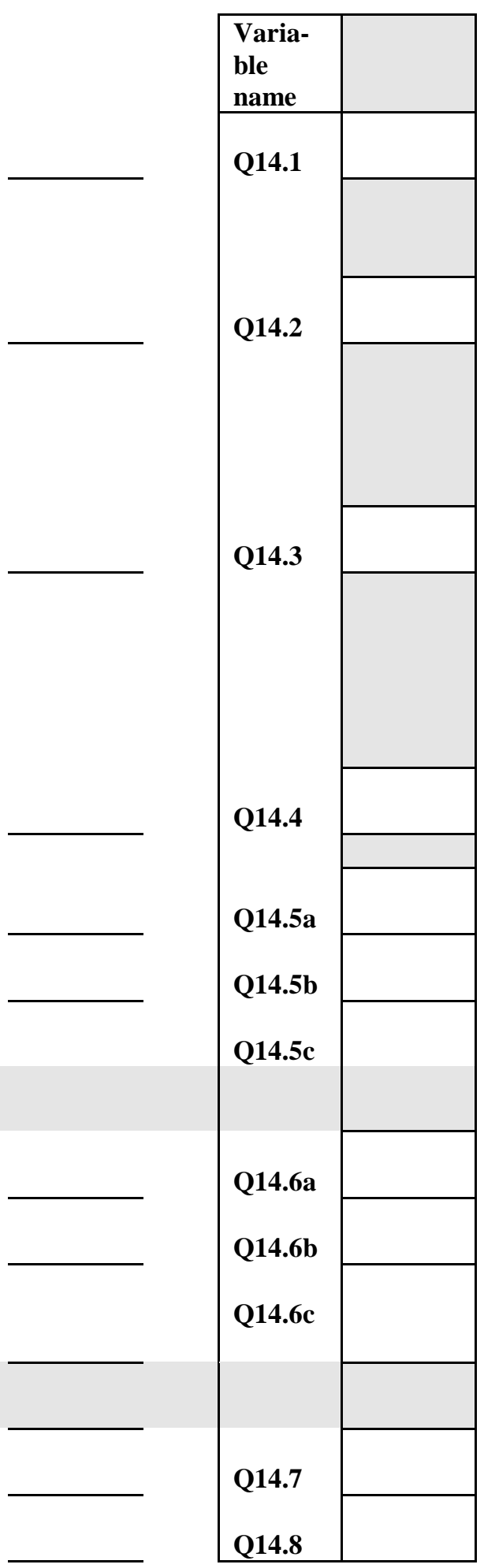

\section{6a What is the voltage of your second car battery? volts \\ 14.6b What is the ampere-hours of your second car battery? ampere-hours}

14.6c How much did the second car battery cost? yuan

14.7 On the average, how much do you spend on recharging for all of your batteries each month? yuan

14.8 How much does each recharge cost? yuan 


\section{Section 14. Electricity from Car Batteries (continued)}

14.9 In general how many recharges per month do you require for all of your batteries? recharges per month

14.10 How many months did your previous battery last? months

(Enter "O" if you did not own any battery before.)

14.11 How long does the battery give you service before the next recharge? days

14.12 What is the distance from your home to the recharge station? kilometers

14.13 Which mode of transport does your household use to go to the recharge station?

Code: $[1]=$ Bicycle

$[2]=$ Motorcycle

$[3]=$ Bus, truck, or car

$[4]=$ Horse

$[5]=$ Cart

$[6]=$ Combination of the above transportation modes

[7] = Other; specify:

14.14 What is the average cost of transport to and from the recharge station? yuan (cost per round trip)

14.15 In general, how many hours per week does your household use electricity from car batteries? hours per week

14.16 On the average, how many hours per month does your household use electricity from a car battery for productive purposes? (Enter " 0 " for no use.)

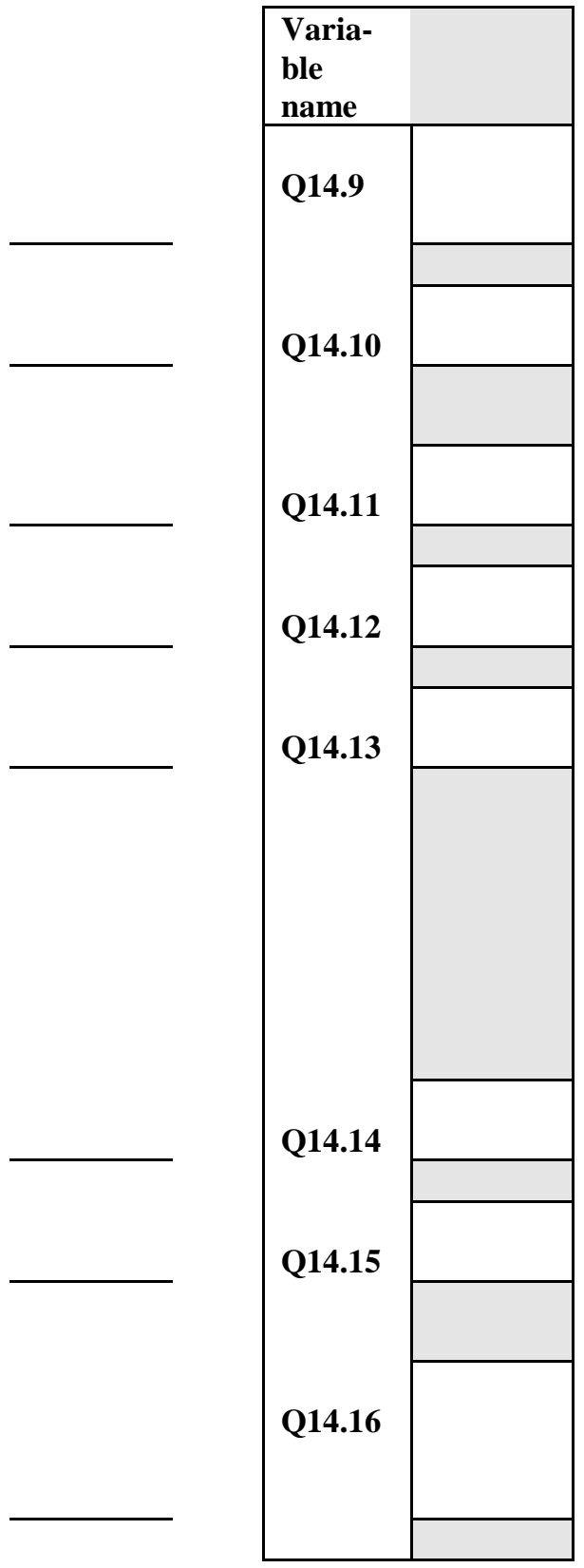




\section{Section 15. Electricity}

15.1 Does your household use electricity that is generated from electric generator and supplies through village or community grid or neighbor or private entrepreneur or your own electric generator set?

Code: $[0]=$ Do not use

\section{(If "Do not use," go to Q16.1.)}

$[1]=$ Use electricity from village- or communityowned generator set

[2] = Use electricity from neighbor- or relativeowned generator set

[3] = Use electricity from family-owned generator set

(Go to Q15.11.)

$[4]=$ Other; specify:

\section{Household uses electricity from village or} community, or from neighbor- or relative-own generator set

(Answer "1" or "2" in Q15.1.)

15.2 How many months has your household had electricity? months

15.3 How many households including your household are sharing electricity from the same source through the same grid with yours? households

15.4 How much does your household pay for electricity per billing period? yuan

15.5 How many days does each bill cover? days

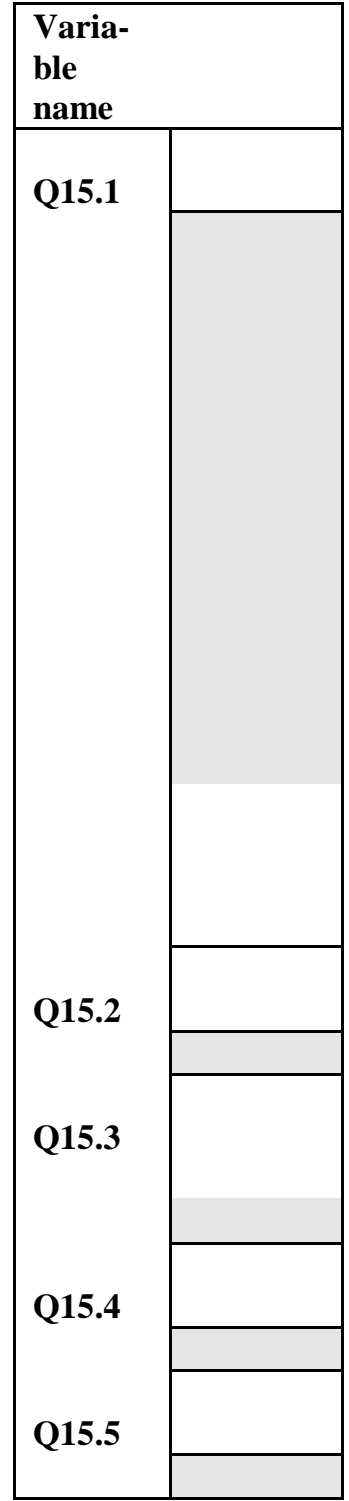


If you share electricity with other households, do you

15.6a pay by $\mathrm{kWh}$ ? Code: $[0]=$ No

$$
[1]=\text { Yes }
$$

15.6b If yes, how much electricity did your family use per billing period? $\mathrm{kWh}$

15.6c If yes, how many yuan per kWh? $\mathrm{kWh}$

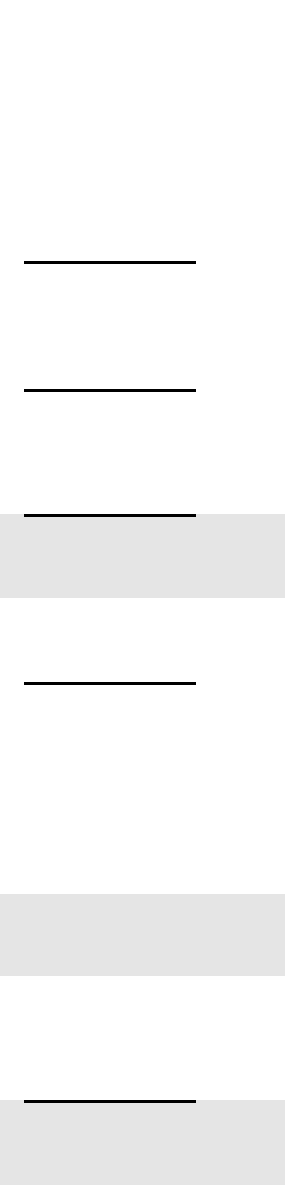

15.9 How many hours of electricity services you receive per day? hours per day yuan per

15.7 Do you pay by the number of light bulbs or tubes and appliances?

Code: $\quad[0]=$ No

$$
[1]=\text { Yes }
$$

15.7a If yes, what is the average wattage of all light bulbs and tubes? watts

15.8 Do you pay in fixed monthly charges?

Code: $[0]=$ No

$$
[1]=\text { Yes }
$$

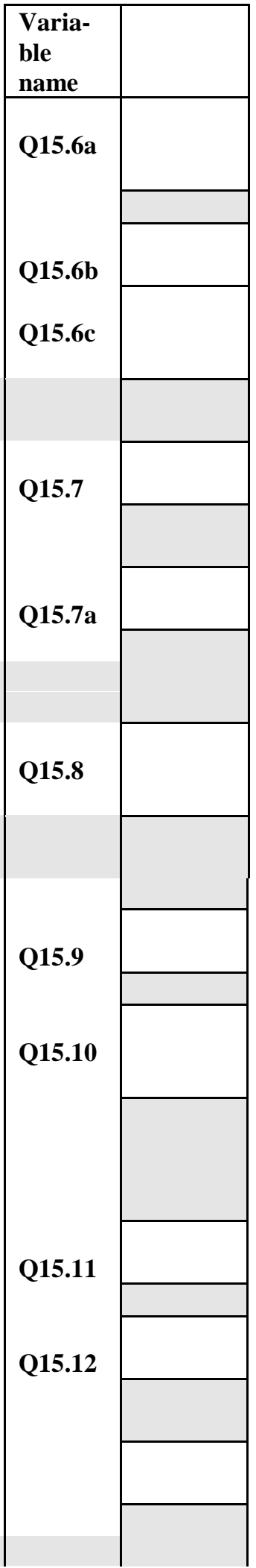

How many households does your household supply

15.13 electricity to? households

(Enter “0” for your own household use only.) 
(Ask Q15.14 to household that answered "1", "2", or "3" in Q15.1.)

15.14 On the average, how many hours in a month does your household use electricity for productive purposes? hours per month (Enter "0" for no use.)

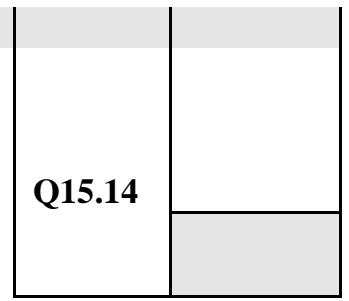




\section{Section 16. Owners of Small Wind Systems}

16.1 How many small wind systems does your household have?

(If household does not have any, fill in "O", and go to Q17.1.)

16.2 What do you think about the price of your small wind system?

Code: $[1]=$ Very expensive

$$
\begin{aligned}
& {[2]=\text { Expensive }} \\
& {[3]=\text { Right price }} \\
& {[4]=\text { Cheap }}
\end{aligned}
$$

I will ask you some questions about your small wind system. Please answer the following questions concerning the size and cost of your system.

(Fill in 20 if the system is 20 watts. If the system is 30 watts, fill in 30. You must then ask to see the system to verify the correct size.)

16.3 What is the size of your small wind system? watts

16.4 How long has your household had its small wind system installed? months

Please tell me about the total costs of each of your wind power system.

16.5a For the small wind system, how much did you pay up front? yuan

(If you paid in full, fill in the total full payment, and go to Q17.1.)

Describe the terms of payment.

16.5b Have to pay yuan per payment,

$16.5 \mathrm{c} \quad$...for a total number of payments.

16.5d How many months does each payment cover? months

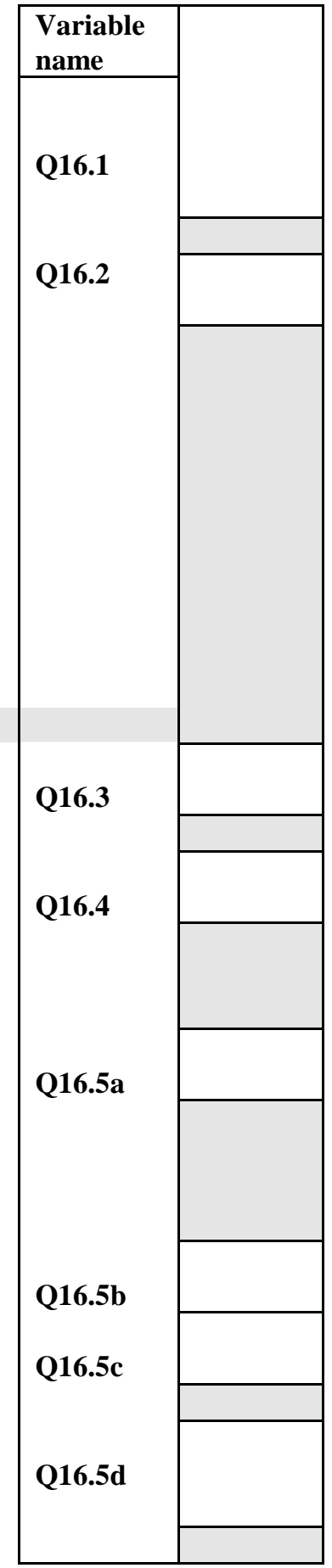




\section{Section 17. Hybrid Systems}

\section{Ownership and Cost of Hybrid Systems}

17.1 How many hybrid systems does your household have? (If household does not have any, fill in " 0 ", and go to Q18.1.)

17.2 What do you think about the price of your hybrid system?

Code: $[1]=$ Very expensive

$$
\begin{aligned}
& {[2]=\text { Expensive }} \\
& {[3]=\text { Right price }} \\
& {[4]=\text { Cheap }}
\end{aligned}
$$

I will ask you some questions about your hybrid system. Please answer the following questions concerning the size and cost of your system.

(Fill in 20 if the system is 20 watts. If the system is 30 watts, fill in 30. You must then ask to see the system to verify the correct size.)

17.3 What is the size of your hybrid system? watts

17.4 How long has your household had its hybrid system installed? months

Please tell me about the total cost of each of your wind power systems.

17.5a For the hybrid system, how much did you pay up front? yuan

(If you paid in full, fill in the total full payment, and go to $Q 18.1$.

Please describe the terms of payment.

17.5b Have to pay yuan per payment,

17.5c ...for a total number of payments.

17.5d How many months does each payment cover? months

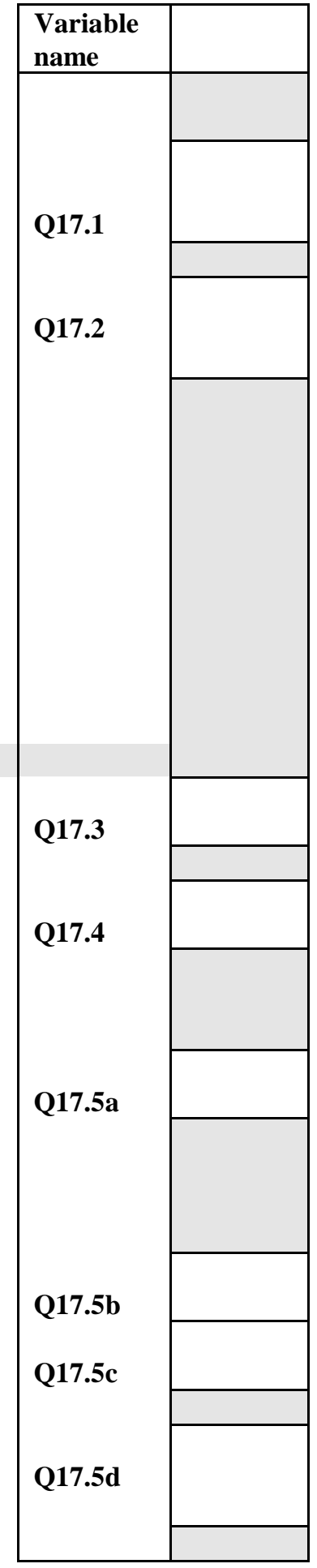


Section 18. Appliances

How many of the following appliances does your household have?

(Enter "0" for "do not have.")

18.1 Fan

18.2 Color television

18.3 Black-and-white television

18.4 Radio/ or tape cassette

18.5 VCR

18.6 Satellite receiver

18.7 Refrigerator

18.8 Freezer

18.9 Washing machine

18.10 Ironing

18.11 Electric shears

18.12 Other; specify:

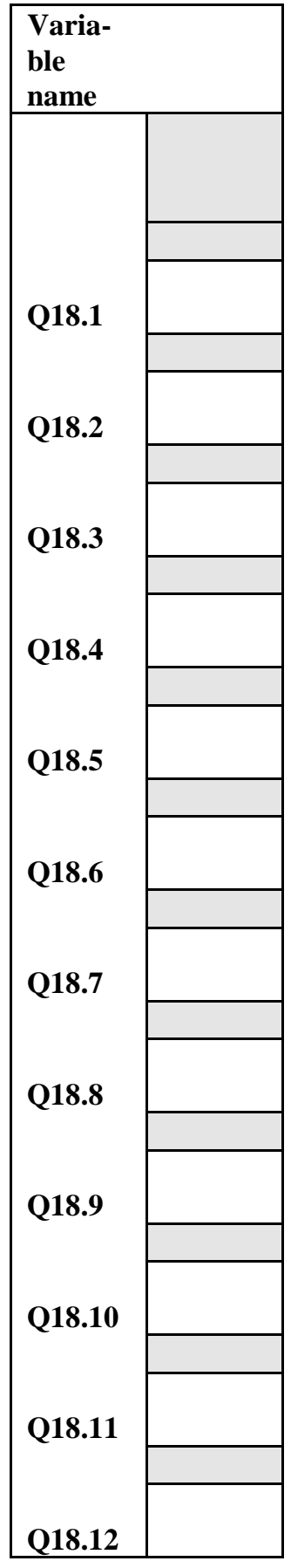




\section{Section 19. Lighting}

Can you please tell me about the type of light bulbs or tubes, their capacity in wattage, how many your household has, and the combined total number of hours all are used for light each day in your household?

Type of light bulb or tube:

Code: $[1]=$ Incandescent light bulb

[2] = Fluorescent light tube

[3] = Compact fluorescent light

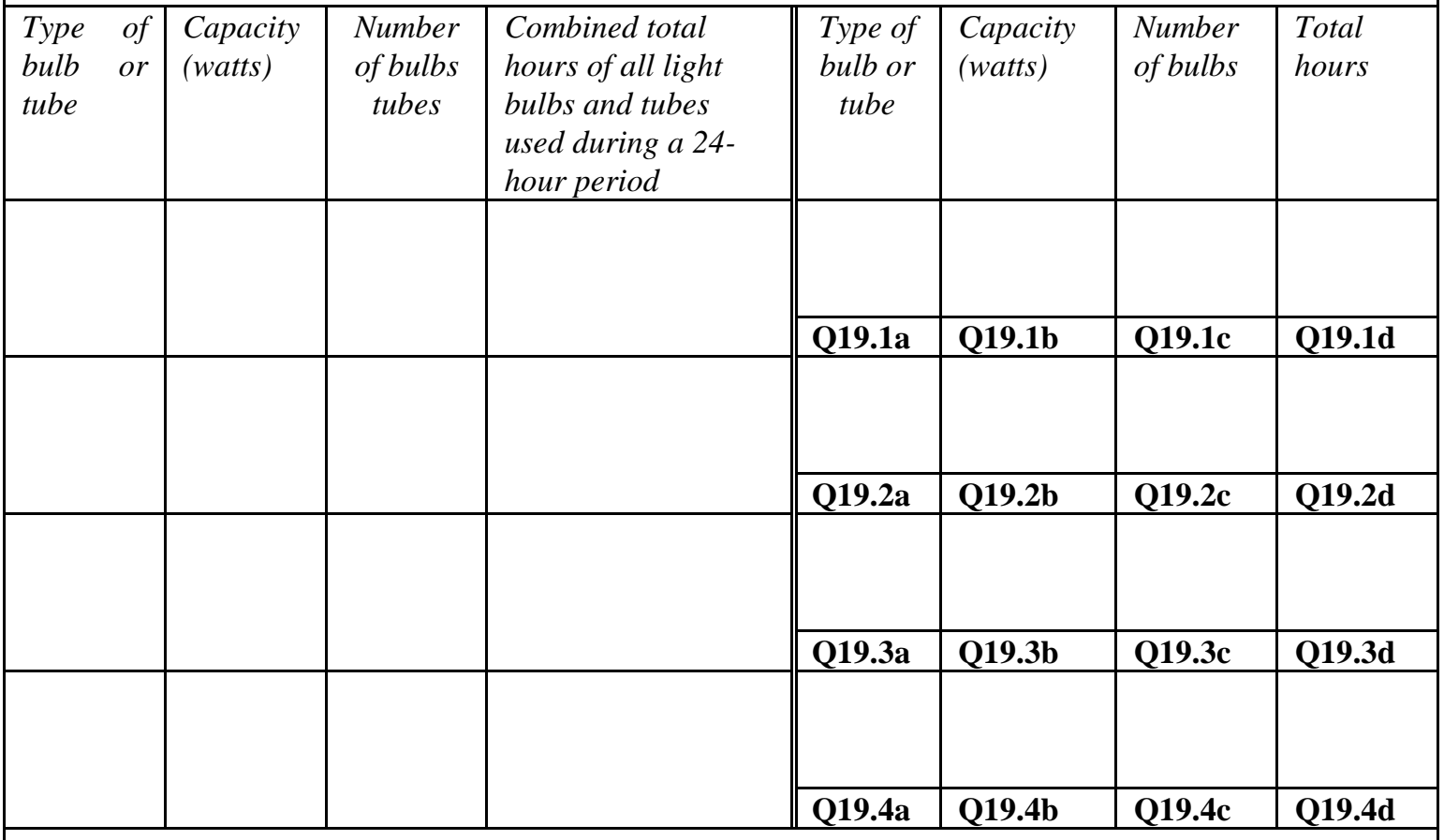


Section 20. Electric Appliances that Use Dry Cell Batteries

How many of the following appliances does your household have?

(Enter "0" for "do not have.")

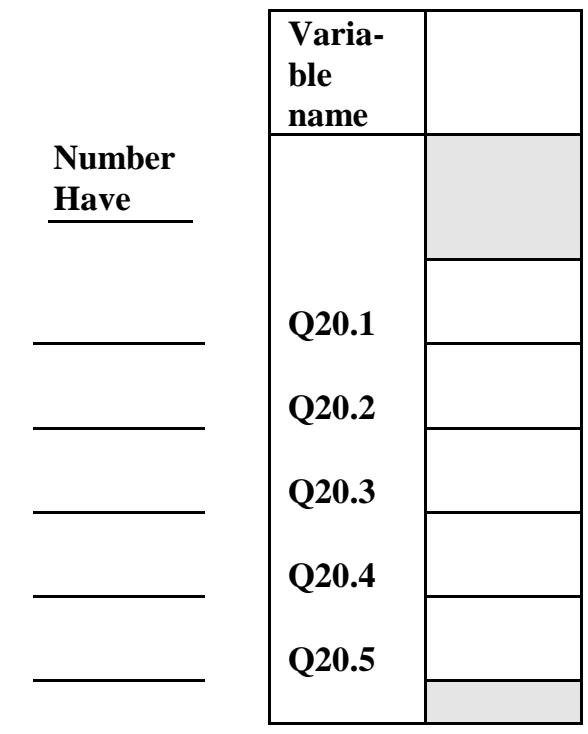

$20.1 \quad$ Flashlights

20.2 Lanterns

20.3 Combined flashlights and lanterns

20.4 Radio and/or tape cassette

20.5 Other; specify:

\begin{tabular}{|l|l|}
\hline $\begin{array}{l}\text { Varia- } \\
\text { ble } \\
\text { name }\end{array}$ & \\
\hline & \\
& \\
Q20.1 & \\
Q20.2 & \\
20.3 & \\
& \\
& \\
\hline
\end{tabular}




\section{Section 21. Nonelectric Lighting Equipment}

21.1 How many kerosene, diesel, or butter wick lamps does your household have? lamps

(Enter "0" for none. If "None," go to Q21.3.)

21.2 How often does your household use kerosene, diesel, or butter wick lamps?

Code: $[0]=$ Never

$$
\begin{aligned}
& {[1]=\text { Some of the time }} \\
& {[2]=\text { Most of the time }} \\
& {[3]=\text { Always }}
\end{aligned}
$$

21.3 How many pressurized kerosene lamps does your household have? lamps

(Enter "0" for none. If "None," go to Q21.5.)

21.4 How often does your household use pressurized lamps?

Code: $[0]=$ Never

$[1]=$ Some of the time

$[2]=$ Most of the time

[3] = Always

21.5 How many hurricane lanterns does your household have? lamps

(Enter "0" for none. If "None," go to Q21.7.)

21.6 How often does your household use hurricane lanterns?

Code: $[0]=$ Never

$[1]=$ Some of the time

$[2]=$ Most of the times

$[3]=$ Always

\subsection{What other nonelectric lighting equipment does your} household have? Specify the equipment, and enter the number owned:

(Enter "0" for none. If “None," go to Q22.1.)

21.8 How often does your household use other nonelectric

lighting equipment?

Code: $[0]=$ Never

$$
\begin{aligned}
& {[1]=\text { Rarely }} \\
& {[2]=\text { Sometimes }} \\
& {[3]=\text { Always }}
\end{aligned}
$$

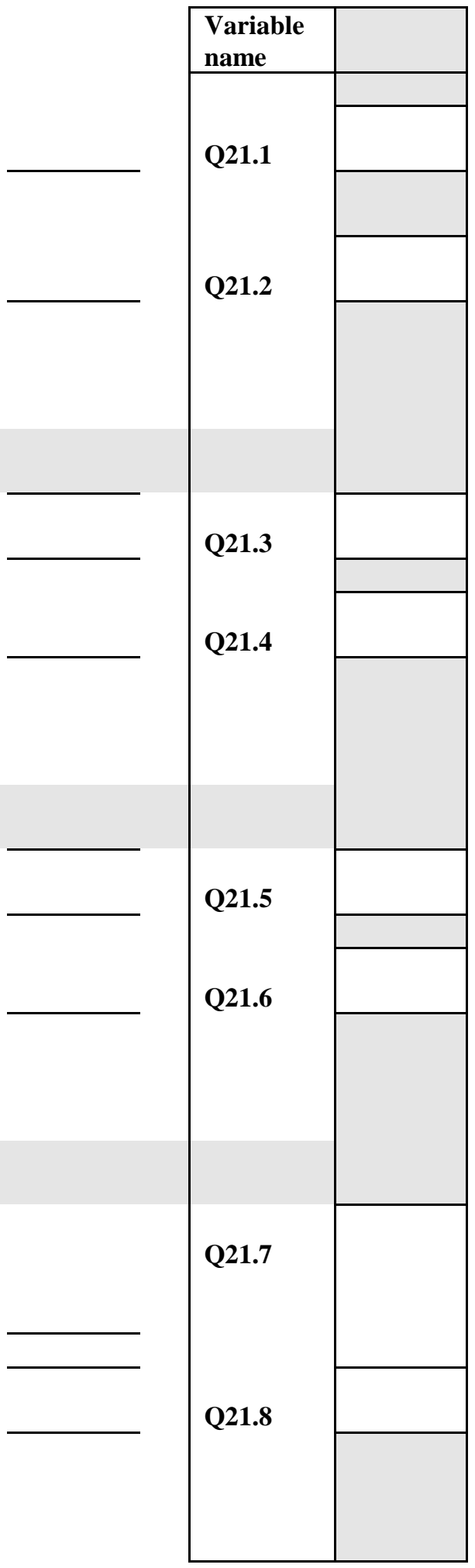


Section 22. Electrical Appliance Acquisition

$\begin{array}{llll}\text { Code: } & {[1]=\text { Bulb or tube }} & {[2]=\text { Radio and/or tape cassette }} & {[3]=\text { Black-and-white television }} \\ & {[4]=\text { Color television }} & {[5]=\text { Washing machine }} & {[6]=\text { Fan }} \\ {[7]=\text { Refrigerator }} & {[8]=\text { iron }} & {[9]=\text { Cooker }} \\ {[10]=\text { Hot plate }} & {[11]=\text { Hi-fi or stereo }} & {[12]=\text { Milling machine }} \\ & & \end{array}$

[15] = Other; specify:

(Use the coding above for the following questions.)

22.1 What is the first appliance you would like to acquire if electricity were to become available to your household?

22.2 What is the second appliance you would like to acquire if electricity were to become available to your household?

22.3 What is the third appliance you would like to acquire if electricity were to become available to your household?

\begin{tabular}{|l|l|}
\hline $\begin{array}{l}\text { Variable } \\
\text { name }\end{array}$ & \\
\hline & \\
& \\
22.1 & \\
$\mathbf{Q 2 2 . 2}$ & \\
\cline { 2 - 2 } & \\
\cline { 2 - 2 } $\mathbf{Q 2 2 . 3}$ & \\
\hline
\end{tabular}


Section 23. Household Attitude toward Electricity Services

The following statements I am about to read to you concern energy use and other issues. Please tell me if you agree or disagree with these statements and how strong your feelings are.

(Use the following coding for the answers.)

Code: [1] = strongly agree

$[2]=$ agree

$[3]=$ no opinion

$[4]=$ disagree

$[5]=$ strongly disagree

23.1 Electricity is very beneficial to production activities.

23.2 Because of good light, children would study more at night; this is very important for children's education.

23.3 Reading is easier with electric lamps compared with kerosene lamps.

23.4 My family feels very secure at night.

23.5 My family is extremely happy with the light we get from our current fuel.

23.6 Electricity is important for our local water supply.

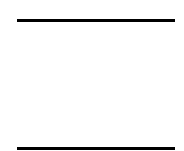

Q23.1

Variable name

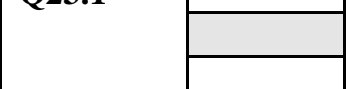

Q23.2

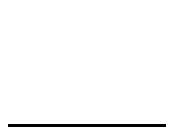

Q23.2

Q23.3

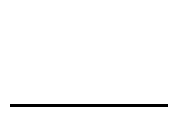

Q23.4

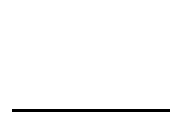

Q23.5

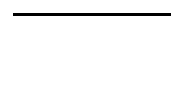

23.7 Car batteries are good source of electricity for lighting.

23.8 PV system is a good source of energy for lighting.

23.9 Lighting with kerosene or diesel can cause health problems.

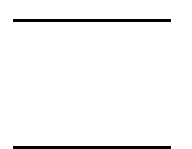

Q23.6

Q23.7

Q23.8

Q23.9

23.10 It is difficult for my family to get news and information.

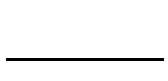


Section 23. Household Attitude toward Electricity (continued)

23.12 Television takes study time away from children.

23.13 I complete work in my house during the evening after it is dark outside.

23.14 We often receive visiting friends, relatives, or neighbors in the evening after it is dark outside.

23.15 Today life is better than it was 5 years ago.

23.16 I am optimistic that life will get better in the future.

23.17 I prefer to pay cash for my major purchase.

23.18 Light at night is useful to keep the herd together.

\begin{tabular}{|l|l|}
\hline \multicolumn{2}{|l|}{$\begin{array}{l}\text { Variable } \\
\text { name }\end{array}$} \\
\hline \multirow{4}{*}{ Q23.12 } & \\
\cline { 2 - 2 } Q23.13 & \\
\cline { 2 - 2 } Q23.14 & \\
\cline { 2 - 2 } Q23.15 & \\
\cline { 2 - 2 } Q23.16 & \\
\cline { 2 - 2 } & \\
\cline { 2 - 2 } Q23.17 & \\
\cline { 2 - 2 } & \\
\cline { 2 - 2 } & \\
\cline { 2 - 2 } Q23.18 & \\
\hline
\end{tabular}




\section{Section 24. Uses of Electricity from Nongrid Energy Sources for Lighting}

Now I would like to ask you some questions about evening activities that require lighting.

Do any household members use lamps in the evening for the following purposes?

$24.1 \quad$ Reading, writing, studying, or cooking (that is, read a newspaper, Bible, or novel; write a letter; do homework for school; prepare for examinations; etc.).

Code: $[0]=$ No

$$
[1]=\text { Yes }
$$

24.2 Generally, how many hours per evening do household members read, write, or study? evening

(Enter "O" for "No use.")

\section{Social Activities, Such as Meetings}

24.3 Generally, how many hours per month do household members usually use light for these social activities? hours per month

(Enter "O" for "No use.")

\section{How many hours per day?}

24.4 How many hours a day are radio, tape, and stereo in your home are turned on? (Enter "O" for "No use.") hours per day

24.5 Television set in your home is turned on per day

(Enter "0" for "No use.")

\section{Section 25. Household Desires to Use Electricity and} Other Infrastructure

Which of the following services you would like to have first, second, and third?

(Enter "1", "2", or "3" to rank the service you would like to have first, second, or third.)

25.1a Clean water

25.1b Electricity

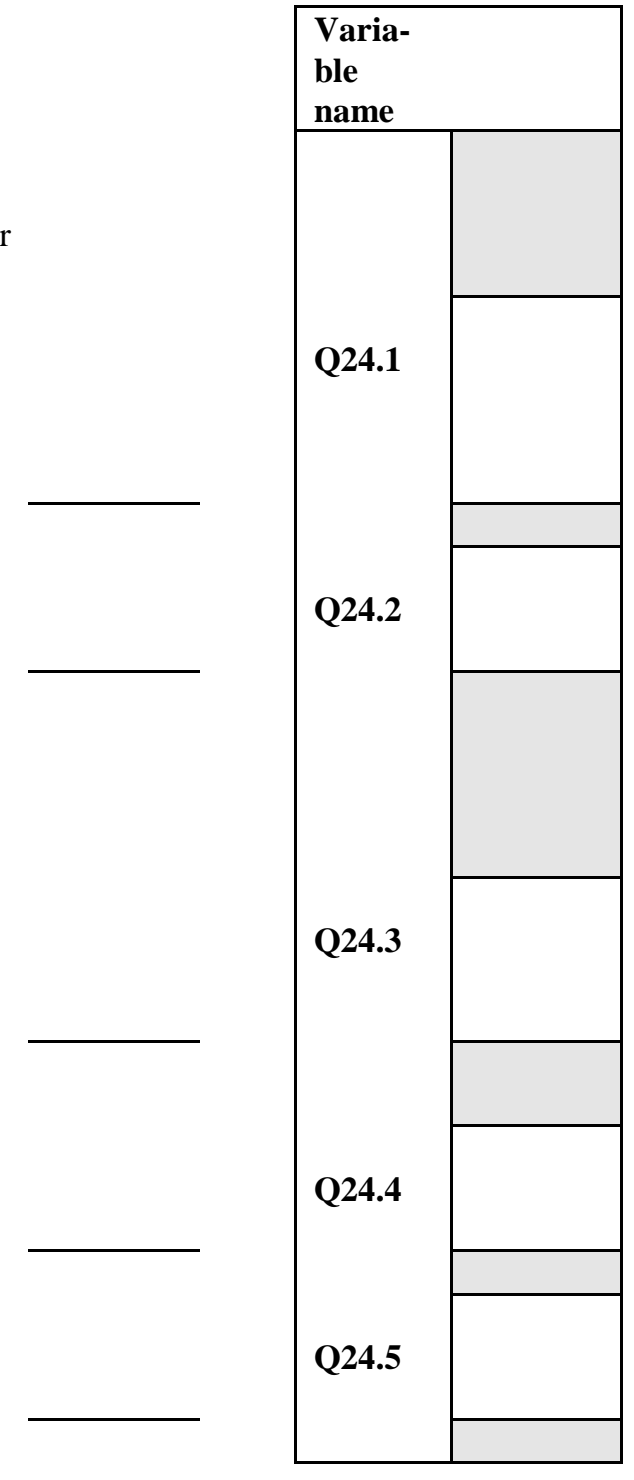

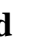


25.1c Irrigation

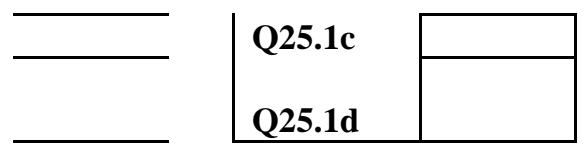

25.1d Road

\section{Section 26. Marketing of Solar PV Systems}

\section{Awareness and Willingness to Purchase Individual Renewable Energy Devices}

The following are lists of small, medium, and large PV systems.

A small PV system (20 watts) could provide energy for two lamp and $10 \mathrm{~W}$ radio for 5 hours per day and would cost about Y 1,700.

A medium PV system (50 watts) could provide energy for two lamps and one 14-inch black-and-white television for 5 hours per day and would cost about Y 3,800.

A large PV system (70 watts) could provide energy for two lamps and one 18-inch color television for 3 hours per day and would cost about Y 6,000.

I am going to ask you if you have already owned it, if you have heard about it, and if you are interested in purchasing one.

\section{Small PV System (20 watts)}

It can provide energy for two lamps and one $10 \mathrm{~W}$ radio for 3 hours' use per day, and costs about Y 1,700.

26.1 Does your household own any 20-watt PV systems?

Code: $[0]=$ Do not own any

$[1]=$ Yes, already owned

(If "Yes," go to Q26.6.)

26.2 Have you heard about this 20-watt PV system?

Code: $[0]=$ No, never heard of it

$[1]=$ Yes, from newspaper or magazine

$[2]=$ Yes, from radio, television

$[3]=$ Yes, from neighbors or friends

$[4]=$ Yes, saw it in store

[5] = Yes, saw a system installed at friend's, government's, or neighbor's

[6] = Yes, other source; specify:

26.3 Are you interested in buying such a 20-watt PV system with cash for about Y 1,700?

Code: $[0]=$ No

$[1]=$ Yes but no money to pay

$[2]=$ Yes

(If "Yes," go to Q26.6.)

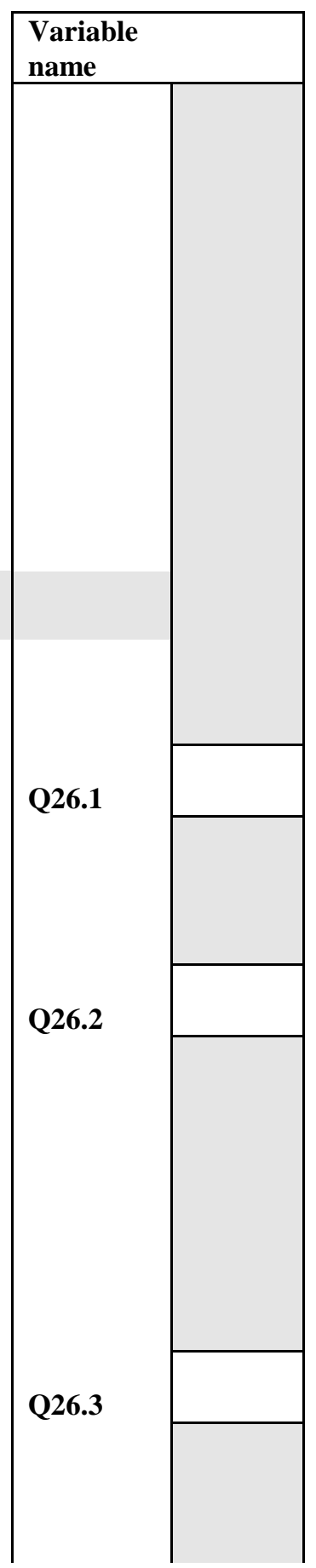


26.4a Are you interested in buying this 20-watt PV system with down payment and credit of 1 -year period?

Code: $[0]=$ No

$[1]=$ Yes but no money to pay

[2] = Yes

(If "Yes," go to Q26.6.)

Section 26. Marketing of Solar PV Systems

\section{Small PV System (20 watts)}

It can provide energy for two lamps and one $10 \mathrm{~W}$ radio for 3 hours' use per day, and costs about Y 1,700.

26.4b Are you interested in buying this 20-watt PV system with a down payment and credit for a 2 -year period?

Code: $[0]=$ No

[1] = Yes, but no money to pay

[2] = Yes

(If “Yes," go to Q26.6.)

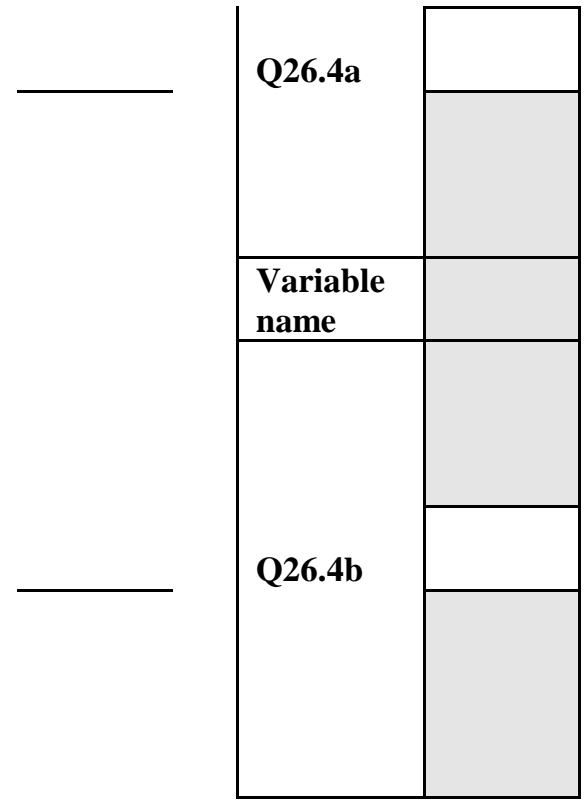


Section 26. Marketing of Solar PV Systems

(continued)

Small Solar PV Systems (20 watts)

26.5 The following are lists of reasons your household has not purchased a 20-watt PV system.

What are your primary and secondary reasons for not purchasing?

Code: $[0]=$ for no reason

[1] = for main reason

[2] = for secondary reason

Reason

I don't know about the system.

System costs too much.

26.5c No convenient location to buy.

26.5d Cannot get credit to buy system.

26.5e Worry about low quality; not easy to operate; service; etc.

26.5f Have had electricity supply, or have had small wind, small diesel generator set, etc.

26.5g Will get grid connection soon or will buy small diesel soon.

26.5h Capacity of the system is not enough for family to use. (If this is the main reason, continue. If it is not the main reason, go to $Q 27.1$.)

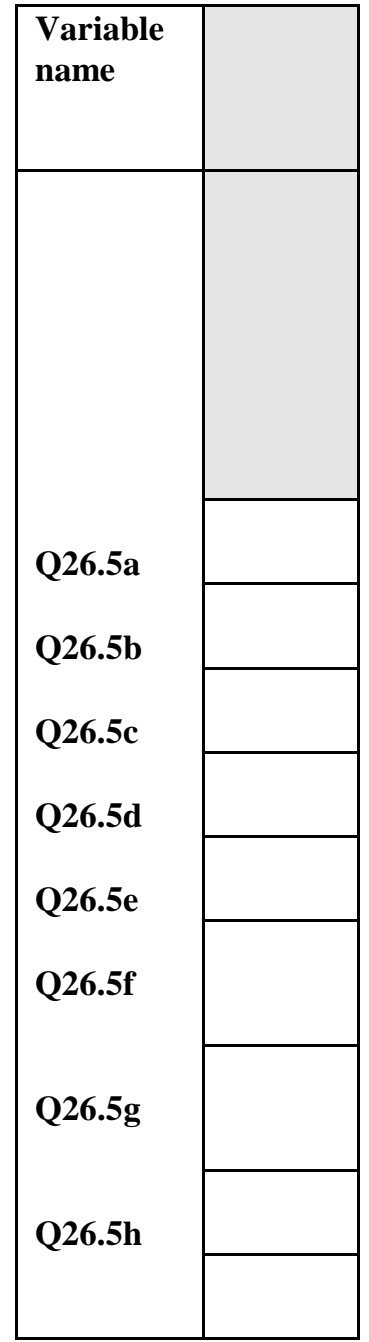


Section 26. Marketing of Solar PV Systems (continued)

Awareness and Willingness to Purchase Individual Renewable Energy Devices

\section{Medium Solar PV System (50 watts)}

This which could provide energy for 2 lamps and 1 14inch black-and-white television for 5 hours per day and costs about Y 3,800.

26.6

$$
\begin{aligned}
& \text { Do you own a } 50 \mathrm{~W} \text { PV system? } \\
& \text { Code: [0] = Do not own any } \\
& \text { [1] = Yes, already owned } \\
& \text { (If "Yes," go to Q26.16.) }
\end{aligned}
$$

26.7 Have you heard about 50 W PV systems?

Code: $[0]=$ No, never heard of it

$$
[1]=\text { Yes, from newspaper or magazine }
$$

[2] = Yes, from radio, television

$[3]=$ Yes, from neighbors or friends

[4] = Yes, saw it in store

[5] = Yes, saw a system installed at friend's, or government's or neighbor's

[6] = Yes, other source; specify:

Are you interested in buying a $50 \mathrm{~W}$ PV system with cash for about Y 3,800?

Code: $[0]=$ No

$$
\begin{aligned}
& {[1]=\text { Yes, but no money to pay }} \\
& \text { [2] = Yes } \\
& \text { (If "Yes," go to Q26.11.) }
\end{aligned}
$$

26.9a Are you interested in buying this $50 \mathrm{~W}$ PV system with a down payment and credit for a 1 -year period?

Code: $[0]=$ No

$$
\begin{aligned}
& {[1]=\text { Yes, but no money to pay }} \\
& {[2]=\text { Yes }} \\
& \text { (If "Yes," go to Q26.11.) }
\end{aligned}
$$

26.9b Are you interested in buying this $50 \mathrm{~W}$ PV system with a down payment and credit for a 2 -year period? (See annex table 2.3.) WHERE IS THIS TABLE TO BE FOUND?]]

Code: $[0]=$ No

$$
\begin{aligned}
& {[1]=\text { Yes, but no money to pay }} \\
& {[2]=\text { Yes }} \\
& \text { (If “Yes," go to Q26.11.) }
\end{aligned}
$$

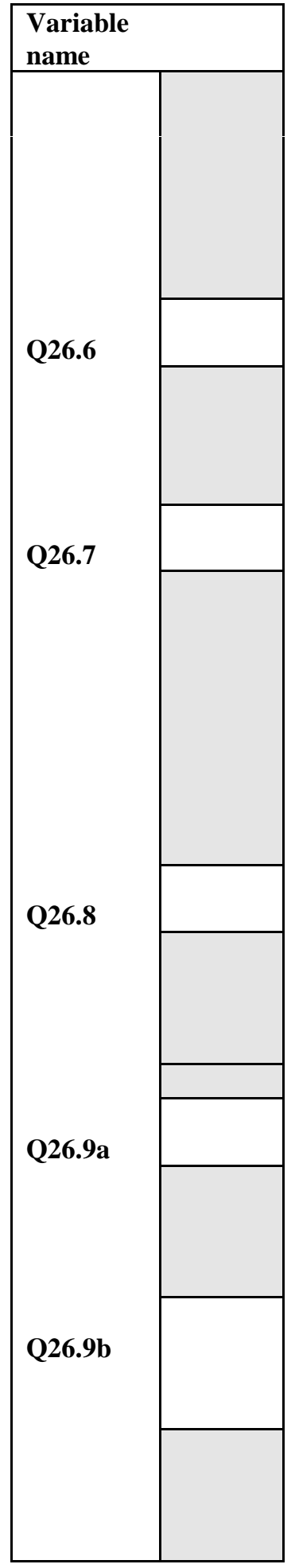


Section 26. Marketing of Solar PV Systems

(continued)

50 W Solar PV Systems

26.10 The following are lists of reasons your household has not purchased a $50 \mathrm{~W}$ PV system.

What are your primary and secondary reasons for not purchasing?

Code:[0] = for no reason

$[1]=$ For primary reason

$[2]=$ For secondary reason

Reason

26.10a I don't know about the system.

26.10b System costs too much.

26.10c No convenient location to buy.

26.10d Cannot get credit to buy system.

26.10e Worry about low quality; not easy to operate; service; etc.

26.10f Have had electricity supply, or have had small wind, small diesel generator set, etc.

$26.10 \mathrm{~g}$ Will get grid connection soon or will buy small diesel soon.

26.10h Capacity of the system is not enough for family to use. (If this is the main reason, continue. If it is not the main reason, go to $Q 27.1$.)

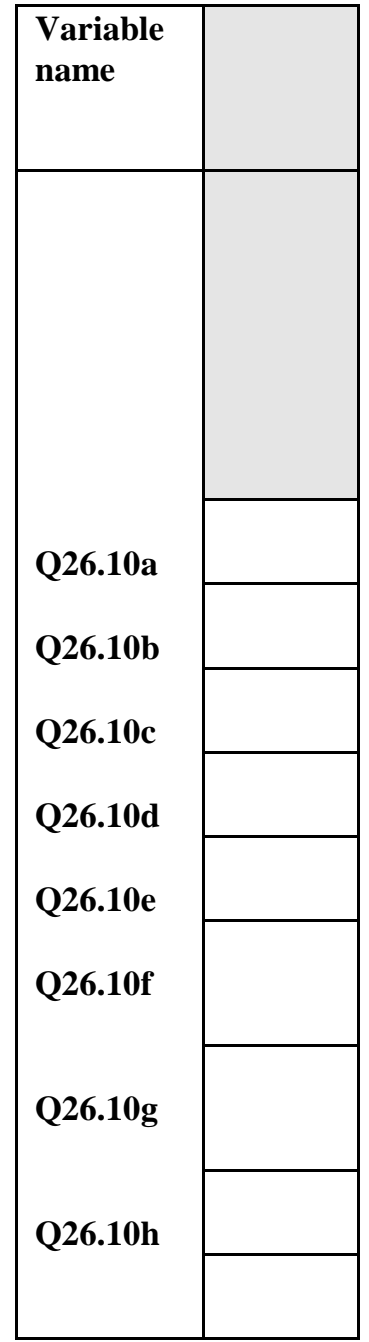


Section 26. Marketing of Solar PV Systems (continued)

Awareness and Willingness to Purchase Individual Renewable Energy Devices

\section{Large Solar PV Systems (70 watts)}

Which could provide energy for 2 lamps and 1 18-inch color television for 3 hours per day and costs about $\mathrm{Y}$ 6,000

26.11 Do you own a 70 W PV system?

Code: $[0]=$ Do not own any

[1] = Yes, already owned

(If “Yes," go to Q26.21.)

26.12 Have you heard about 70 W PV system?

Code: $[0]=$ No, never heard of it

$[1]=$ Yes, from newspaper or magazine

$[2]=$ Yes, from radio, television

$[3]=$ Yes, from neighbors or friends

$[4]=$ Yes, saw it in store

$[5]=$ Yes, saw a system installed at friend's, government's, or neighbor's

[6] = Yes, other source; specify:

26.13 Are you interested in buying $70 \mathrm{~W}$ PV system with cash, about Y 6,000?

Code: $[0]=$ No

$[1]=$ Yes, but no money to pay

$[2]=$ Yes

(If "Yes," go to Q27.1.)

26.14a Are you interested in buying this $70 \mathrm{~W}$ PV system with down payment and credit of 1 year period?

Code: $[0]=$ No

$[1]=$ Yes, but no money to pay

$[2]=$ Yes

(If “Yes," go to Q27.1.)

26.14b Are you interested in buying this $70 \mathrm{~W}$ PV system with a down payment and credit for a 2 -year period?

Code: $[0]=$ No

$[1]=$ Yes, but no money to pay

$[2]=$ Yes

(If "Yes," go to Q27.1.)

26.14c Are you interested in buying this $70 \mathrm{~W}$ PV system with a down payment and credit for a 3 -year period?

Code: $[0]=$ No

$[1]=$ Yes, but no money to pay

$[2]=$ Yes

(If “Yes," go to Q27.1.)

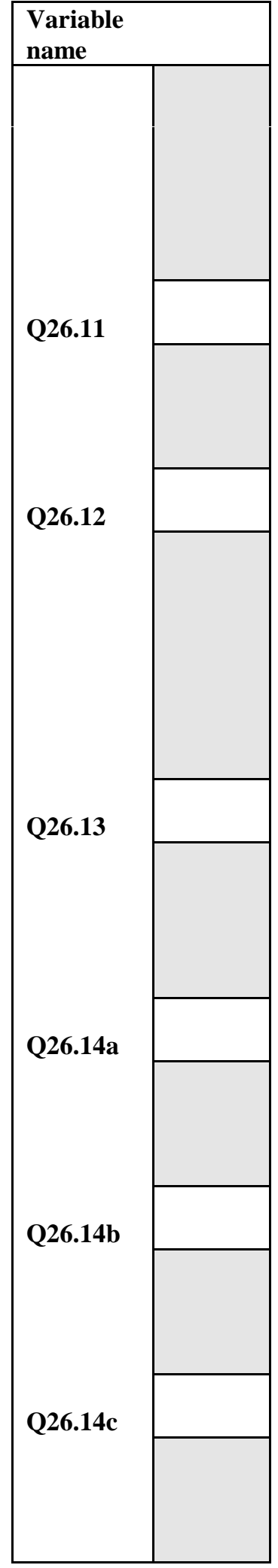


Section 26. Marketing of Solar PV Systems

(continued)

70 W Solar PV Systems

26.15 The following are lists of reasons your household has not purchased a $70 \mathrm{~W}$ PV system.

What are your primary and secondary reasons for not purchasing?

Code: $[0]=$ for no reason

[1] $=$ For primary reason

$[2]=$ For secondary reason

26.15a I don't know about the system.

$26.15 b \quad$ System costs too much.

26.15c No convenient location to buy.

26.15d Cannot get credit to buy system.

Reason
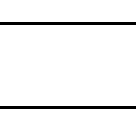

26.15e Worry about low quality; not easy to operate; service; etc.

26.15f Have had electricity supply, or have had small wind, small diesel generator set, etc.

26.15g Will get grid connected soon or will buy small diesel soon.

26.15h Capacity of the system is not enough for family to use.

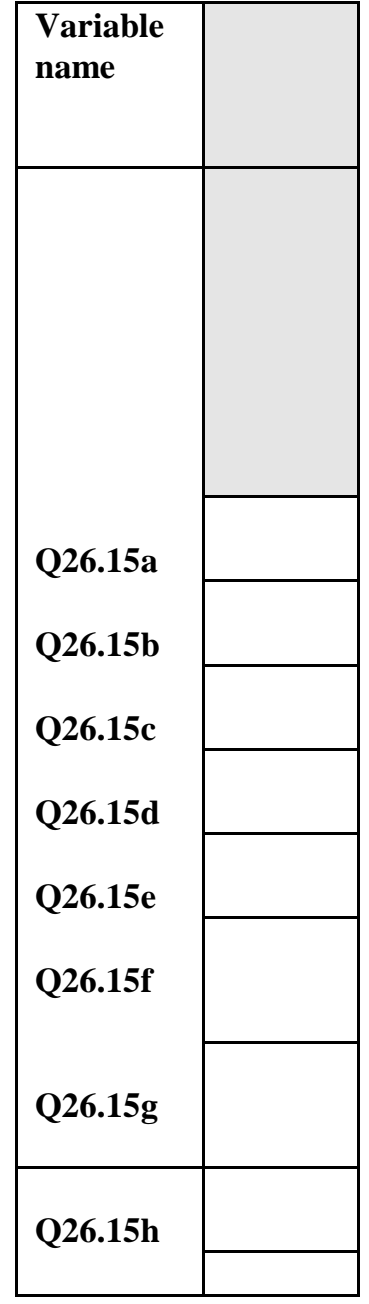


Section 27. Marketing of Hybrid Systems

Awareness and Willingness to Purchase individual Renewable Energy Devices

I am going to ask you if you have already owned a hybrid system, if you have heard about it, and if you are interested in purchasing one.

\section{Small Hybrid Power System}

The capacity is 38 watts of $\mathrm{PV}$ and 100 watts of wind power, and it costs about Y 3,500-4,000.

27.1 Do you own any small hybrid power system?

Code: $[0]=$ Do not own any

$$
\begin{aligned}
& \text { [1] = Yes, already owned } \\
& \text { (If "Yes," go to Q28.1.) }
\end{aligned}
$$

27.2 Have you heard about small hybrid power systems?

Code: $[0]=$ No, never heard of them

$[1]=$ Yes, from newspaper or magazine

$[2]=$ Yes, from radio, television

$[3]=$ Yes, from neighbors or friends

$[4]=$ Yes, saw them in store

[5] = Yes, saw a system installed at friend's, government's, or neighbor's

$[6]=$ Yes, other source; specify:

If you have heard of small hybrid power system,

27.3 Are you interested in buying it with cash, that is, paying cash?

Code: $[0]=$ No

$[1]=$ Yes, but no money to pay

$[2]=$ Yes

(If "Yes," go to Q28.1.)

27.4 Are you interested in buying a small hybrid power system with a down payment and credit?

Code: $[0]=$ No

[1] = Yes, but no money to pay

$[2]=$ Yes

(If "Yes," go to Q28.1.)

27.5 The following are lists of reasons your household has not purchased a small hybrid power system.

What are your primary and secondary reasons?

Code:[0] $=$ for no reason

[1] = For primary reason

$[2]=$ For secondary reason

27.5a I don't know about the system.

$27.5 \mathrm{~b}$ System costs too much.

27.5c No convenient location to buy.

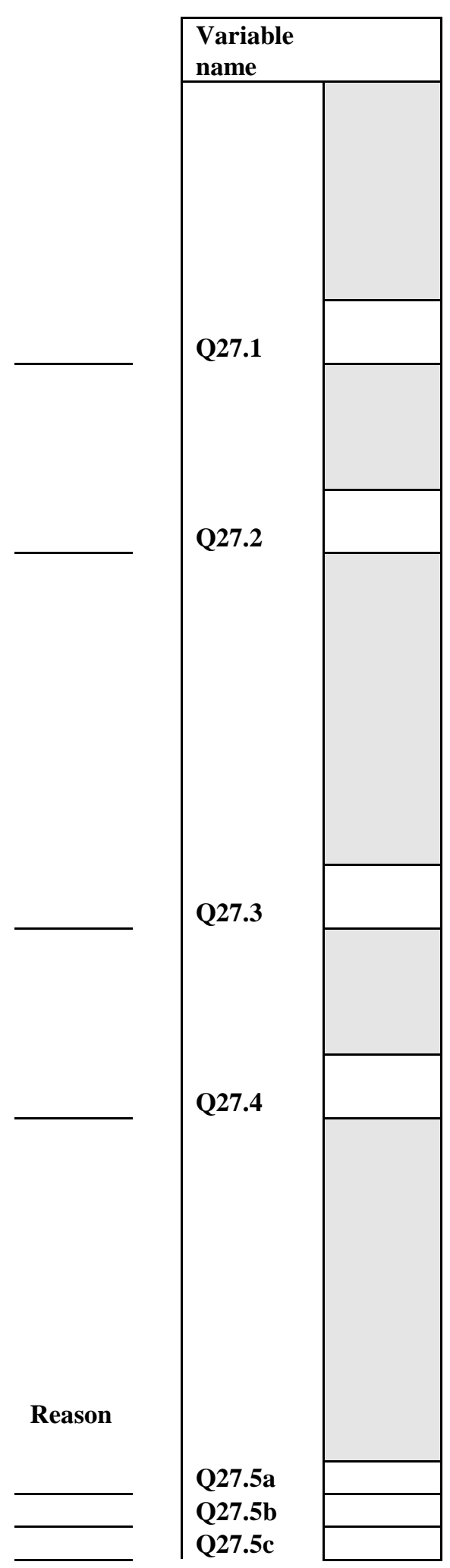


27.5d Cannot get credit to buy system.

27.5e Worry about low quality; not easy to operate; service; etc.

$27.5 \mathrm{f}$

Have had electricity supply, or have had small diesel generator set, etc.

27.5g Will get grid connection soon or will buy small diesel soon.

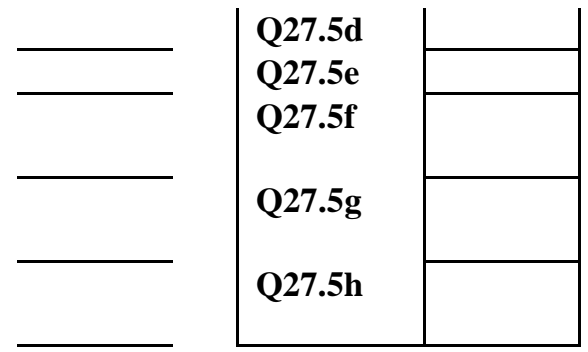

27.5h Unsafe; if the wind turbine is broken down by strong winds, it will damage my house. 


\section{Section 28. Owners of Solar PV Systems}

\section{Ownership and Cost of Solar PV Systems}

28.1 How many PV systems does your household have? (If household does not have any, fill in " 0 ", and end the interview.)

28.2 What do you think about the price of your PV system?

Code: $[1]=$ Very expensive

$$
\begin{aligned}
& {[2]=\text { Expensive }} \\
& {[3]=\text { Right price }} \\
& {[4]=\text { Cheap }}
\end{aligned}
$$

I will ask you the about the size of each of the solar PV systems you have. If you have only one system, answer only the first question. If you have two, answer the first and second system, and so forth.

(Fill in 20 if the system is 20 watts. If the system is 30 watts, fill in 30. You must then ask to see the system to verify the correct size.)

28.3a What is the size of your first PV system? watts

28.3b How long has your household had your first PV system installed? months

Please tell me about the total cost of each of your PV systems.

28.3c For the first system, how much did you pay up front? yuan

(If you paid in full, fill in the total full payment, and go to $Q 28.4 a$.)

Describe the terms of payment.

28.3d Have to pay yuan per payment,

28.3e for a total number of payments.

28.3f Number of months per payment payment months per

\section{4a What is the size of your:} second $\mathrm{PV}$ system? watts

28.4b How long has your household had its second PV system installed? months

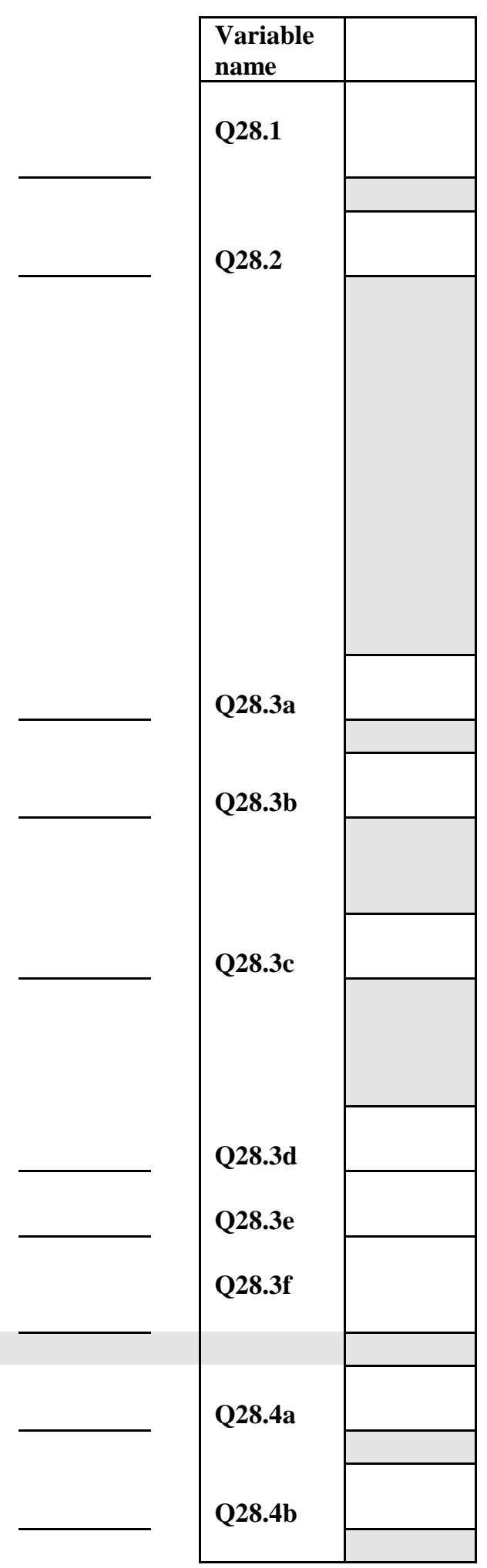




\section{Ownership and cost of solar PV system (continued)}

Tell me about the total costs of your second PV system.

28.4c For the second system, how much did you pay up front? _ yuan

(If you paid in full, fill in the total full payment, and go to $Q 28.5$ a.)

Describe the terms of payment.

28.4d Have to pay yuan per payment,

$28.4 \mathrm{e}$ for a total number of payments.

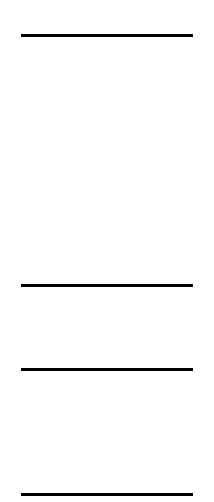

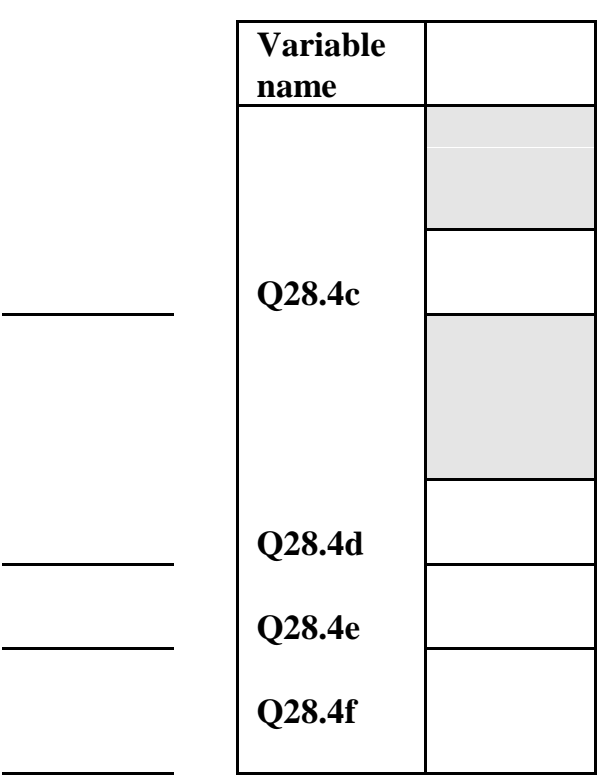


Section 28. Owners of Solar PV Systems System Quality

28.5 How many times has your PV system broken down since you bought it? times

(Enter "0" for never broken down, and go to Q28.11.)

28.6 Do you have to change any of your PV panel?

Code: $[0]=$ No

[1] Yes

When the systems have broken down, which of the following parts have broken down?

Code: $[0]=$ No

$[1]=$ Yes

\section{Battery}

28.7b Lamp (light bulb or tube)

28.7c Charge or discharge controller

28.7d Solar panel

28.7e AC/DC Adapter

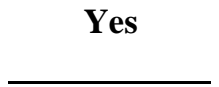

No

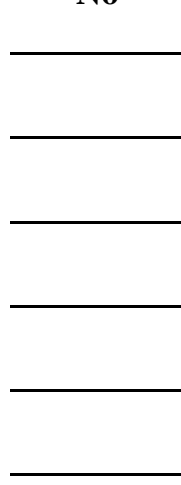

28.8 What is the average cost per repair?

yuan

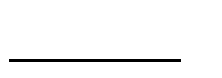

\begin{tabular}{|l|l|}
\hline Variable \\
name
\end{tabular}

28.10 How long does your light bulb or tube last? months months

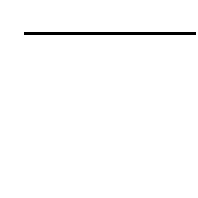


Section 28. Owners of Solar PV Systems Quality of Services from Your Solar PV System

28.11 Last year, what was the total number of days your PV system was out of order?

28.12 What are the reasons your household has to live without electricity from PV system?

Code: [1] = Normal waiting time for repair when it is out service

[2] $=$ Difficult to find spare parts

[3] = Could not find any repair person, or repair person is not available.

$[4]=$ Repair is too costly

[5] = Have to go long distance to repair or buy part

[6] $=$ System is under warranty, and service provided is slow

[7] = Other reasons; specify:

28.13 When or if the PV system breaks down, how do you have it repaired?

Code: $[1]=$ Technician or repair person come to our home to repair

[2] = Take to repair shop

[3] = No services available in township area

$[4]=$ No services available in county area

[5] = Other; specify:

When or if you have to take your PV system for repair, what is the mode of transportation, the distance, and the travel costs incurred?

28.14 Travel by:

Code: $[1]=$ Bicycle

[2] = Motorcycle

$[3]=$ Bus or truck

$[4]=$ Horse

$[5]=$ Cart

$[6]=$ Combination of the above transportation modes

[7] = Other; specify:

28.15 Distance to repair shop: kilometers

(Enter "0 km" for repair services provided at home.)

28.16 To have your system repaired, how much do you spend on travel (to and from) costs for each repair? yuan

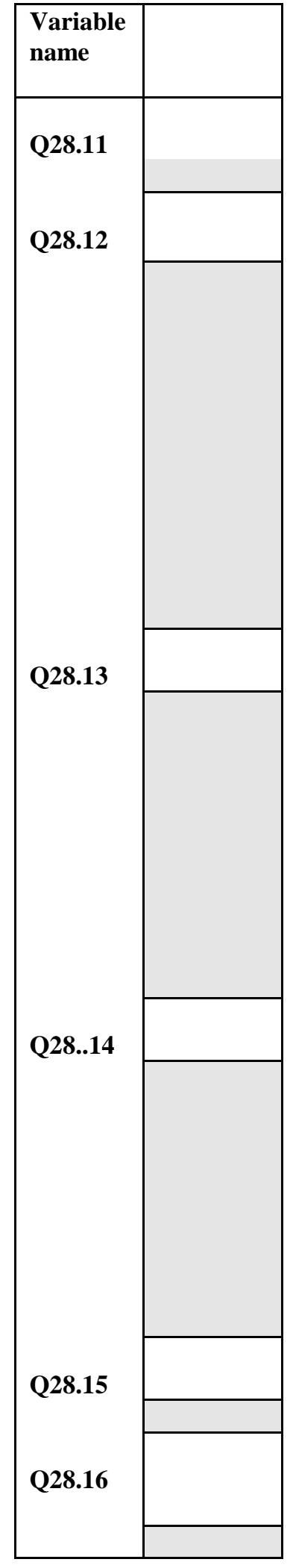


Section 28. Owners of Solar PV Systems Uses of Electricity from Your Solar PV System for Household Activity

28.17 Generally, how many hours per evening does your household have light on for general area lighting? hours per evening

28.18 Generally, how many hours per evening do household members usually use light for reading, writing, or studying? hours per evening

28.19 Generally, how many hours per evening do household members usually use light for handicrafts in the home industry? hours per evening

28.20 Generally, how many hours per evening is the television set in your home turned on? (Enter " 0 " for "Do not have television set.")

28.21 Do you use light for herding (for example, for collecting sheep in bad weather, such as during storms)?

Code: $[0]=$ No

$$
[1]=\text { Yes }
$$

28.22 Generally, do household members usually use light for social visits?

Code: $[0]=$ No

$$
[1]=\text { Yes }
$$

28.23 How many light bulbs does your household have?

a bulbs

28.23 What is the average capacity of all your lights?

b watts

28.23 What is the total number of hours of all light used per

c evening? hours per evening

28.24 Do you use electricity generated from your PV system for productive purposes?

Code: $[0]=$ No

$$
[1]=\text { Yes }
$$

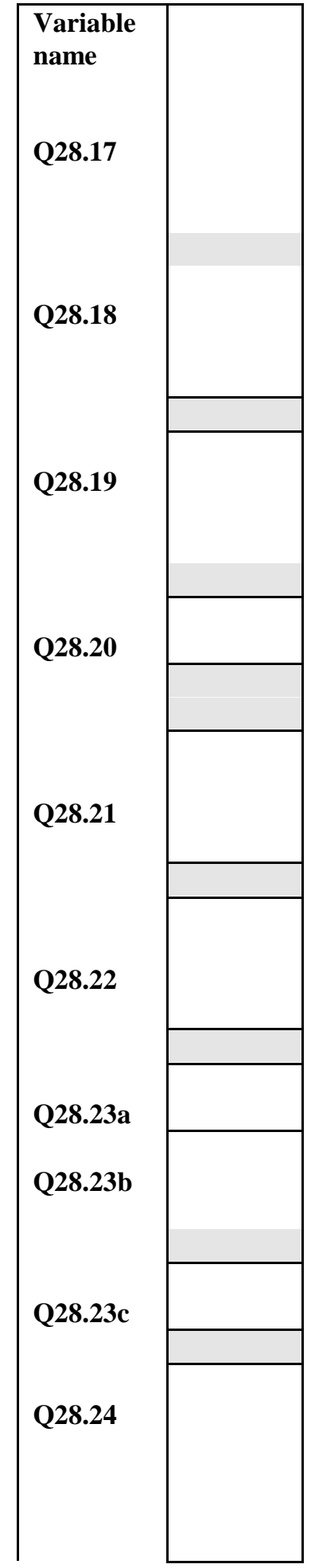


Section 28. Owners of Solar PV Systems Attitudes toward Solar PV Systems

28.25 Electricity generated from your PV system is:

Code: [1] = Not enough for household need

[2] = Just enough for household need

[3] = More than enough for household need

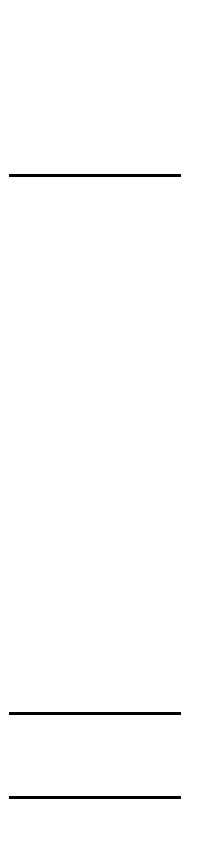

28.26 Reason my household decided to obtain PV system home is:

Code: $[0]=$ No reason

[1] = Primary reason

[2] = Secondary reason

28.26a For children education.

$28.26 \mathrm{~b}$ For better lighting.

28.26c To watch television.

28.26d PV system is cheaper than kerosene and other fuels.

28.27 What is the greatest benefit of the PV system to my household?

(Use the following coding for answer.)

Code: $[0]=$ No reason

$[1]=$ Main reason

$[2]=$ Secondary reason

28.27a Accessing to news and information from television and radio.

28.27b Providing lighting for my family.

28.27c Giving entertainment from television, radio, and tape cassette.

28.27d Enabling family members to read, write, and study in the evening longer than before.
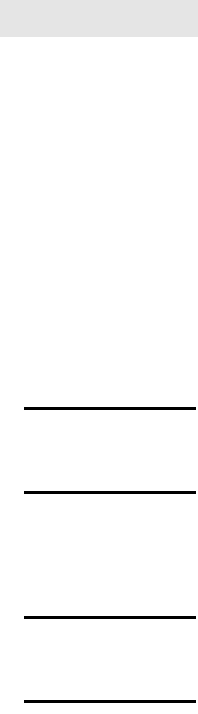

28.27e Enabling us to do more work.

28.28 How do you rate the degree of satisfaction with the performance of your PV system?

Code: $[1]=$ High

[2] = Rather high

[3] = Fair

$[4]=$ Rather low

[5] $=$ Low

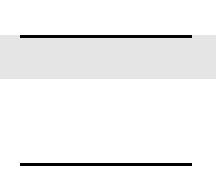

28.29 Would you recommend a PV system to your relatives
Q28.26a

Q28.26b

Q28.26c

Q28.26d

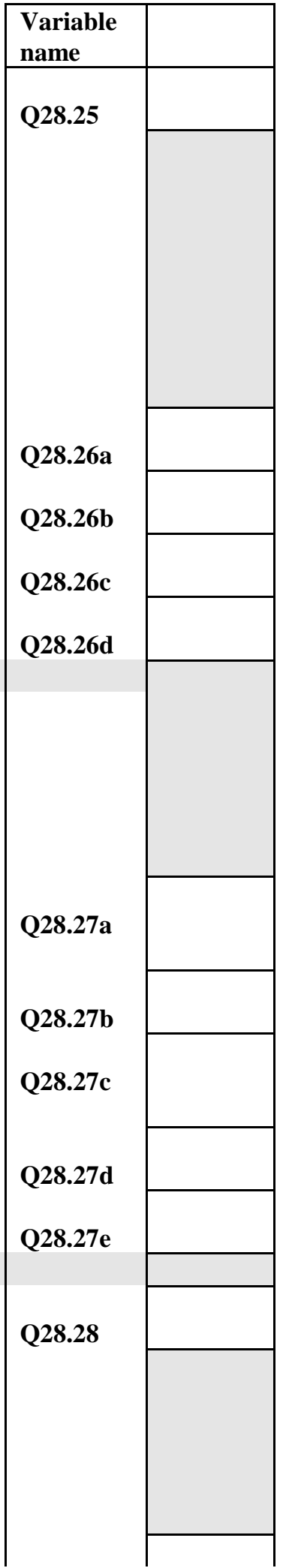


or friends?

Code: $[0]=$ No

$$
[1]=\text { Yes }
$$

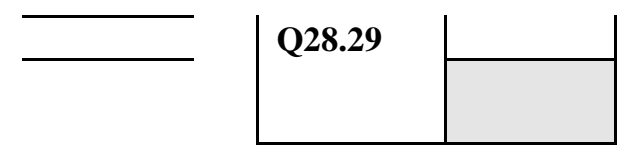

Section 28. Owners of Solar PV Systems

\section{Lifestyle}

28.30 Since installing the PV system, does your family stay up later than before?

Code: $[0]=$ No

$[1]=$ Go to bed at the same time as before

$[2]=$ Stay up later

\begin{tabular}{|l|l|}
\hline $\begin{array}{l}\text { Variable } \\
\text { name }\end{array}$ & \\
\hline \multirow{3}{*}{$\mathbf{Q 2 8 . 3}$} & \\
\cline { 2 - 2 } & \\
& \\
\hline
\end{tabular}




\section{BIBLIOGRAPHY}

Cabraal, Anil, Mac Cosgrove-Davies, and Loretta Shaeffer. 1996. Best Practices for Photovoltaic Household Electrification Programs: Lessons from Experiences in Selected Countries. Asia Technical Department Series, World Bank Technical Paper No. 324. Washington, D.C.: World Bank.

CRED (Center for Renewable Energy Research and Development). 1998. "CRED/World Bank Solar PV Market Survey.” Beijing: CRED.

China Market Survey. 1998. "Remote Markets for Renewable Energy: PV and Wind Systems in Northwest China."

China Statistical Yearbook. 1996. Beijing: China Statistical Publishing House.

ESMAP. 1999. Lao PDR Institutional Development for Off-Grid Electrification, ESMAP Report No. 215/99, World Bank, Washington, D.C.

ESMAP. 1996. Energy For Rural Development in China: Joint Chinese/ESMAP Study in Six Counties. ESMAP Report No. 183/96, World Bank, Washington, D.C.

World Bank. 1995. Photovoltaic Applications in Rural Areas of the Developing World. World Bank Technical Report Number 304, Energy Series, World Bank, Washington, D.C. 